\title{
Risicofactoren voor galsteenziekte : een epidemiologische benadering = Risk factors for gallstone disease : an epidemiological approach
}

Citation for published version (APA):

Thijs, C. T. M. (1991). Risicofactoren voor galsteenziekte : een epidemiologische benadering = Risk factors for gallstone disease : an epidemiological approach. [Doctoral Thesis, Maastricht University]. Rijksuniversiteit Limburg. https://doi.org/10.26481/dis.19911219ct

Document status and date:

Published: 01/01/1991

DOI:

10.26481/dis.19911219ct

Document Version:

Publisher's PDF, also known as Version of record

Please check the document version of this publication:

- A submitted manuscript is the version of the article upon submission and before peer-review. There can be important differences between the submitted version and the official published version of record.

People interested in the research are advised to contact the author for the final version of the publication, or visit the DOI to the publisher's website.

- The final author version and the galley proof are versions of the publication after peer review.

- The final published version features the final layout of the paper including the volume, issue and page numbers.

Link to publication

\footnotetext{
General rights rights.

- You may freely distribute the URL identifying the publication in the public portal. please follow below link for the End User Agreement:

www.umlib.nl/taverne-license

Take down policy

If you believe that this document breaches copyright please contact us at:

repository@maastrichtuniversity.nl

providing details and we will investigate your claim.
}

Copyright and moral rights for the publications made accessible in the public portal are retained by the authors and/or other copyright owners and it is a condition of accessing publications that users recognise and abide by the legal requirements associated with these

- Users may download and print one copy of any publication from the public portal for the purpose of private study or research.

- You may not further distribute the material or use it for any profit-making activity or commercial gain

If the publication is distributed under the terms of Article 25fa of the Dutch Copyright Act, indicated by the "Taverne" license above, 


\section{RISICOFACTOREN VOOR GALSTEENZIEKTE}

Een epidemiologische benadering

\section{RISK FACTORS FOR GALLSTONE DISEASE}

An epidemiological approach 



\section{RISICOFACTOREN VOOR GALSTEENZIEKTE}

Een epidemiologische benadering

\section{RISK FACTORS FOR GALLSTONE DISEASE}

An epidemiological approach

\section{PROEFSCHRIFT}

ter verkrijging van de graad van doctor

aan de Rijksuniversiteit Limburg te Maastricht,

op gezag van de Rector Magnificus, Prof. Mr. M.J. Cohen,

volgens het besluit van het College van Dekanen,

in het openbaar te verdedigen

op donderdag, 19 december 1991

om 16,00 uur

door

Carolus Thomas Maria Cornelius Nicolaas Thijs 
PROMOTOR:

Prof. Dr. P.G. Knipschild

\section{BEOORDELINGSCOMMISSIE:}

Prof. Dr. P.J. Brombacher (voorzitter)

Prof. Dr. J.W. Arends

Prof. Dr. G.P. van Berge Henegouwen, Rijksuniversiteit Utrecht

Prof. Dr. J.M.A. van Engelshowen

Prof. Dr. P.B. Soeters

(C) 1991 vakgroep Epidemiologie en Biostatistiek,

Rijksuniversiteit Limburg, Postbus 616, NL-6200 MD Maastricht, the Netherlands

Niets uit deze uitgave mag worden verveelvoudigd en/of vermenigvuldigd door middel van druk, fotocopie, microfilm of op welke andere wijze dan ook zonder voorafgaande schriftelijke toestemming van de uitgever.

\section{CIP-GEGEVENS KONINKLIJKE BIBLIOTHEEK, DEN HAAG}

Thijs, Carolus T.M.C.N.

Risicofactoren voor galsteenziekte: een epidemiologische benadering / Carolus T.M.C.N. Thijs. - Maastricht : Rijksuniversiteit Limburg, Vakgroep Epidemiologie en Biostatistiek Proefschirift Maastricht. - Met lit opg.

ISBN 90-74130-02-X

Druk: Datawyse Maastricht/ Krips Repro Meppel

Omslagontwerp: Jan Eggen, AV-dienst Rijksuniversiteit Limburg

Fotografie: Engelbert Schins, AV-dienst Academisch Ziekenhuis Maastricht

In het kader van het onderzoek dat de grondslag vormde voor dit proefschrift ontving de auteur een studiebeurs van de organisatie voor Nederlands Wetenschappelijk Onderzoek NWO.

In de drukkosten wan dit proefschrift werd bijgedragen door Inpharzam Nederland BV, Organon Nederland BV, Schering Nederland BV, en de Stichting Dr. Ir. J.H.J. van de Laar. 


\section{INHOUD / CONTENTS}

INLEIDING

ARTIKELEN / PAPERS 7

1 HYPOTHESE / HYPOTHESIS

2 HDL-CHOLESTEROL

3 ALCOHOL

4 ZWANGERSCHAP / PREGNANCY

5 DE PIL / THE PILL - REVIEW

6 DE PIL/THE PILL

7 VETZUCHT EN LINNEN / OBESITY AND SLIMMING

8 PEULVRUCHTEN / LEGUME

9 ZONNEBADEN EN HUIDTYPE / SUNBATHING AND SKIN TYPE 105

10 PREVALENTIE VAN GALSTENEN / PREVALENCE OF GALLSTONES 111

$\begin{array}{lr}\text { BESCHOUWING } & 119\end{array}$

$\begin{array}{ll}\text { SAMENVATTING } & 127\end{array}$

$\begin{array}{ll}\text { DANKWOORD } & 129\end{array}$

$\begin{array}{ll}\text { CURRICULUM VITAE } & 131\end{array}$ 



\section{SUMMARY IN ENGLISH}

This thesis addresses risk factors of gallstone disease, primarily alcohol use and use of oral contraceptives, and the role of serum lipids. These and some other risk factors were evaluated with an epidemiological case-control approach.

The core of the thesis comprises a series of ten papers in English. An exception is the first paper, which is in Dutch (with an English summary at the end). In an introductory chapter the background is sketched. A concluding chapter globally discusses the results and the methodology. The compilation of the papers unfortunately brings with it some repetitive description of methods. On the other hand, it has the advantage that each paper is self-contained.

The first paper was written at the start of the studies. It describes the background at that time and the central hypotheses. Alcohol use could protect against the occurrence of gallstone disease by influencing serum lipids, especially by raising serum HDL cholesterol level. Other factors affecting serum lipids are considered as well: the use of oral contraceptives ("the pill"), and obesity and weight reduction ("slimming").

Results on serum lipids are presented in the second paper. Gallstone risk appears to be highest if a low serum HDL cholesterol level is accompanied by a high triglyceride level. Results of multivariate analysis suggest that serum lipids are more closely linked to the pathogenesis of gallstones than obesity. The third paper addresses alcohol use and gallstone disease. Special attention is paid to the problem that people with gallstones may decrease their alcohol use because of gastrointestinal symptoms (protopathic bias). This is evaluated in a series of case-control studies with various study designs. It is concluded that protopathic bias has led to an overestimation of the protective effect of alcohol use in earlier studies.

The fourth paper discusses the importance of specification of risk periods in etiologic research. The point is illustrated with data on pregnancy and gallstone disease. The effect of pregnancy is shown to be limited in duration: in the first five years after a pregnancy the occurrence rate of gallstone disease is more than doubled; beyond that period no further effect is found. In a systematic review of the literature on pill use and gallbladder disease (paper 5) we contend that in most studies risk periods are not 
sufficiently specified to be able to estimate the supposed transient effect. Nevertheless, the information available indicates such a transient effect, although the effect is probably small. The results of our case-control study (paper 6) are consistent with this. However, when many other risk factors are controlled for, the results change substantially, and the consistency largely disappeares. This suggests that estimates of the effect of pill use on the occurrence of gallstone disease can be strongly biased by risk-period specific confounding. Unfortunately we cannot indicate whether this leads to over- or underestimation.

The seventh paper attempts to disentangle the effects of obesity and slimming on the risk of acute gallstone disease. It shows that in fat people slimming does not increase the long term risk.

The last three papers present studies that are not primarily related to the central hypotheses. When the data collection for our studies was completed, a new hypothesis emerged in the literature: consumption of legumes could possibly cause the development of gallstones. We were able to evaluate this hypothesis with data that were coincidentally available in our studies. Unexpectedly, we found that regular legume consumption was associated with a two times lower risk of gallstone disease (paper 8). The ninth paper reports a study addressing the question whether people with a light skin type are at increased risk of gallstone formation if they often engage in sunbathing. The results are affirmative, but more research is needed. The last paper presents data on the prevalence of gallstones in the Netherlands, as a by-product of our studies (paper 10). The prevalence increases with age to reach $16 \%$ in men and $40 \%$ in women in the highest age category. More than one third of the men and half of the women with gallstones have already undergone a gallbladder operation.

The concluding chapter begins with a general discussion of the results of the studies. Finally I give my personal view on the methodology of etiological research. There is a need for better specification of hypotheses, especially with respect to the effect period, and the delineation of external and intermediate factors. In addition, the impact of possible biases should be evaluated in the particular setting of the study. As a consequence, each risk factor of interest deserves a separate analysis, if not a separate study. It is argued that scientific inference requires consideration of a multitude of hypotheses - partially exclusive and partially supplementary - much like differential diagnosis. 


\section{INLEIDING}

\section{Vraagstelling}

Toen wij ons een aantal jaren geleden afvroegen waardoor galstenen zo vaak voorkwamen, was er wel iets bekend over de ontstaansmechanismen (pathogenese), maar weinig over oorzaken. In de oudere leerboeken heette het nog dat de typische galsteenpatiënt de volgende kenmerken heeft: "Fair, Fat, Fertile, Forty and Female" (blond, dik, vruchtbaar, veertiger, en vrouw): de fameuze vijf " $F$ " $s$. Later werd deze uitspraak naar het rijk der fabelen verwezen ${ }^{2}$. Tezelfdertijd begon er meer aandacht te komen voor chronische ziekten, ziekten die door hun frequente voorkomen, lange duur en ernstige symptomen of complicaties een aanzienlijke ziektelast in de bevolking met zich meebrengen. Bij obducties werden vaak galstenen aangetroffen ${ }^{3}$. Bij het merendeel van de operaties voor acute galblaasontsteking (cholecystitis) of galkoliek werden galstenen aangetroffen. Of dyspepsie (min of meer vage, veel voorkomende maag- en buikklachten) ook veroorzaakt werden door galstenen, en een goede indicatie vormde voor operatie, werd echter betwijfeld ${ }^{4}$. In ieder geval behoorde de galsteenoperatie (cholecystectomie) tot de top-tien van de heelkundige ingrepen.

Tegen deze achtergrond stelden wij ons de vraag wat belangrijke oorzaken van galstenen waren. Omdat de meeste galstenen in Westerse landen voor het grootste deel uit cholesterol bestaan, was er lange tijd gezocht naar een relatie met cholesterol in de voeding en in het bloedserum. Dit had nooit veel opgeleverd, behalve het inzicht dat de meeste proefdiersoorten anders met cholesterol in de voeding omgaan dan de mens. Well waren er aanwijzingen dat, net als bij de relatie tussen coronaire hartziekte en cholesterol, ook andere serumlipiden wan belang zijn. Met name zou een verband met galstenen eerder moeten worden gezocht in de verschillende fracties van de lipoproteinnen waarin cholesterol in het bloedserum worden getransporteerd. Alcoholgebruik zou kunnen beschermen tegen galsteenziekte door een verhoging wan een wan die serumlipoproteïnen, het HDL (high-density lipoproteïne).

Rond deze centrale hypothese werd een onderzoek gepland naar mogelijke risicofactoren voor galsteenziekte die in de bevolking wijd verbreid zijn, en derhalve potentieel een belangrijke bijdrage aan het optreden van galsteenziekte konden vormen. Behalve alcoholgebruik werd onder meer gedacht aan het gebruik van orale anticonceptiva ("de pil"). De achtergronden en de toenmalige hypothesen worden besproken in het eerste 
artikel. Over het eigen onderzoek wordt gerapporteerd in de daarop volgende vijf artikelen, waarin ook steeds een literatuuroverzicht is opgenomen over het betreffende onderwerp. Een uitzondering is pilgebruik; hieraan is een apart overzichtsartikel gewijd (artikel 5).

Twee risicofactoren voor galsteenziekte zijn nooit echt betwist. Zwangerschap gaat gepaard met een hoger risico op galstenen, en galstenen komen vaker voor bij dikke mensen. Het laatste betekent niet automatisch dat afvallen het risico op galsteenziekte verkteint. Er waren aanwijzingen dat snelle gewichtsreductie, zoals met maagverkleinende operaties beoogd wordt, gepaard gaat met het veelvuldig optreden van gallstenen, die deels ook weer oplossen'. Onbekend was of dit ook gebeurt bij vrijwillige gewichtsreductie door het volgen van vermageringskuren ("lijnen"). Het is de vraag of het voordeel van een lager risico op galstenen bij een lager lichaamsgewicht opweegt tegen het vaker optreden van galstenen tijdens een vermageringskuur. Onderzoek hiernaar wordt beschreven in het zevende artikel.

\section{Methode}

Traditioneel worden drie typen van epidemiologisch onderzoek onderscheiden waarin het optreden van ziekte in verband wordt gebracht met zijn determinanten (in dit geval oorzakelijke determinanten, risicofactoren). In een experiment worden etiologisch vergelijkbare groepen geformeerd van personen zonder de ziekte, waarbinnen door het lot wordt bepaald wie blootgesteld zal worden aan de bestudeerde risicofactor en wie niet. In een cohortonderzoek worden groepen geselecteerd die al blootgesteld zijn, zodat de onderzoeker de toewijzing van de risicofactor en de vergelijkbaarheid niet in de hand heeft. In beide typen onderzoek worden de deelnemers gevolgd in de tijd om het optreden van de ziekte vast te stellen. In het derde type onderzoek, het patiênt-controle onderzoek is de volgorde omgekeerd. Bij patiënten met de ziekte wordt de blootstelling aan de risicofactor in het verleden nagegaan. Hetzelfde wordt gedaan bij een geschikte controlegroep. Hier heeft de onderzoeker ook de selectie van deelnemers naar niveau van blootstelling niet in de hand. Bovendien is moeilijker vast te stellen of de blootstelling aan de risicofactor wel aan het optreden van de ziekte voorafgaat.

Voor het bestuderen van risicofactoren van galsteenziekte werd gekozen voor een patient-controle onderzoek. Het belangrijkste voordeel ten opzichte van cohortonderzoek is dat deelnemers niet hoeven te worden gevolgd in de tijd. Het idee bestond dat de latentietijd tussen blootstelling aan risicofactoren en het optreden van galsteenziekte vele jaren bedroeg, zo niet decennia. Daarmee zouden de resultaten van een patiënt-controle onderzoek eerder beschikbaar kunnen zijn. Een experiment was om redenen die zich laten raden al helemaal uitgesloten, afgezien nog van de onmogelijkheid om aan mensen een bepaald niveau van bijvoorbeeld serumlipiden toe te wijzen.

De veronderstelde lange latentietijd en het gegeven dat galstenen waak met aspecifieke klachten zoals dyspepsie gepaard gaan, brengt een aantal problemen met zich mee die in patiënt-controle onderzoek extra aandacht vereisen. Behalve de in 
epidemiologisch onderzoek steeds weerkerende aandachtspunten informatievertekening, selectievertekening en confounding gaat het om de volgende twee problemen.

Buikklachten die langere tijd bestaan voordat de diagnose galstenen gesteld wordt, kunnen de patiënt ertoe brengen on bijvoorbeeld minder alcohol te gebruiken. Omdat het retrospectief niet mogelijk is te bepalen wanneer galstenen ontstaan zijn in een individueel geval, bestaat het gevaar dat oorzaak en gevolg door elkaar wordien gehaald. Dit wordt protopathische vertekening genoemd ( $\pi \rho \omega \tau 0-\pi \alpha \theta \eta=$ het vroegste lijden). Door aanvullend onderzoek met verschillende onderzoeksopzetten waarmee protopathische vertekening theoretisch vermeden kon worden, werd dit probleem geëvalueerd (artikel 3).

Een tweede probleem houdt verband met de tjjd tussen blootstelling aan de risicofactor en het optreden van galstenen. Intuïtief voelden we bij de opzet van het onderzoek wel aan dat bij een lange latentietijd ver teruggevraagd moet worden over blootstelling in het verleden. Over hoe dergelijke tijdspecifieke informatie geanalyseerd moest worden, bestond echter nog weinig idee, ook niet in de epidemiologische literatuur. Bij de relatie tussen pilgebruik en galsteenziekte kwam dit het duidelijkste tot uitdrukking. Er werd op basis van eerder onderzoek verondersteld dat pilgebruik gepaard ging met een verhoogd risico dat slechts enkele jaren aanhield. Een oplossing werd gevonden in het onderscheiden van verschillende risicoperiodes. Aan de hand van een dergellike analyse van de gegevens over een welbekende relatie, die tussen zwangerschap en galsteenziekte, werd het belang van het specificeren van risicoperiodes toegelicht en ter discussie gesteld (artikel 4).

\section{Overig onderzoek}

In dit proefschrift zijn drie artikelen opgenomen over ander onderzoek dat min of meer een uitvloeisel was van het centrale onderzoek naar risicofactoren van galstenen. De achtergrond van deze onderzoeken wordt hier kort weergegeven.

Toen de gegevens voor ons eigen onderzoek net verzameld waren, werd in de literatuur melding gemaakt van een volkomen nieuwe hypothese. Een Chileense onderzoeksgroep veronderstelde dat galstenen zo vaak bij Chilenen en Noordamerikaanse Indianen voorkomen omdat dezen veel peulvruchten eten. In een humaan experiment bleek de consumptie van peulvruchten de verzadiging van gal met cholesterol te doen toenemen ${ }^{6}$. Aangezien in onze vragenlijst vragen opgenomen waren over het gebruik van peulvruchten (overigens ten behoeve van ander onderzoek), kon deze hypothese direct geëvalueerd worden (artikel 8).

Hoe men bij de vijf " $F$ 's is gekomen op "Fair" (blond haar, blauwe ogen, lichte huidskleur), is niet helemaal duidelijk. Ik was niet weinig verbaasd toen ik in 1990 werd benaderd voor hulp bij een onderzoek dat hierop aansloot. De vraag was of mensen met een lichte huid, die in de zon gemakkelijk verbranden, vaker galstenen krijgen wanneer zij desondanks waak zonnebaden. Het betrof een patiënt-controle onderzoek waarvann de gegevens al verzameld waren, maar de onderzoeker zelf twijfelde aan de informativiteit van het onderzoek. Dit onderzoek werd voorgelegd aan vakgroepgenoten, kritisch beoor- 
deeld ten aanzien van de onderzoeksopzet, en informatief bevonden. Vervolgens hebben wij de gegevens nader geanalyseerd en over de resultaten gerapporteerd (artikel 9).

De onderzoeken leverden als nevenproduct gegevens op over hoe vaak galstenen vóorkomen. De publicatie hiervan is als toegift in de artikelenserie opgenomen (artikel $10)$.

\section{Referenties}

1. Shutrock S. Disseastes of the liver and biliary system (third edition). Oxford: Blackwell Scientific Publications, 1963 , p. 641.

2. Bdilorial. Tacts and fallacies about gall stones. Brit Med J1981; 283; 171 .

3. Breil $M$, Marker DJP. The world alistribution of gallstones. Int J Epidemiol $1976 \%$ :5: $334-41$.

4. Knipschild P. Dyspepsie en galstenen. The Practitioner (Nederlandse vitgave) 1984; $1: 1125-9$.

5. Nervi $F_{0}$ Covarrubias $C$, Bravo $P_{\text {; }}$ et al. Influence of legume intake on bilary lipids and cholesterol saturation in young Chilean mein. Gastroenterology $1989,96: 825-30$.

6. Wallchow $\mathrm{DA}_{4}$ Hall $\mathrm{JC}_{\mathrm{H}}$ Whiting $\mathrm{MJ}$, ell al. Prevalence and treatment of gall stones after gastric bypass surgery for morbid obesity.

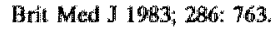


ARTIKELEN / PAPERS 



\title{
1 \\ HYPOTHESE
}

\author{
Alcohol, pil en HDL-cholesterol in relatie tot gallstenen \\ - een hypothese \\ Carel Thijs en Paul Knipschild \\ Capaciteitsgroep Epidemiologie, Rijksuniversiteit Limburg
}

Er zijn aanwijzingen dat alcoholgebruik beschermt tegen galstenen, en dat een laag serum-HDL-cholesterol gepaard gaat met een verhoogd risico op galstenen. Omdat alcohol het serum-HDL verhoogt, achten we het mogelijk dat alcohol een beschermende werking op het ontstaan van galstenen uitoefent via verhoging wan het serum-HDL. Als deze hypothese juist is, verwachten we dat ook andere factoren die het HDL. beïnvloeden (pilgebruik, roken, lichaamsbeweging) van invloed zijn op het ontstaan van galstenen. Teneinde mogelijke leefwijze-afhankelijke risicofactoren voor galstenen aan te tonen, en de rol van HDL hierin te bepalen, hebben we een patiënt-controle onderzoek gepland. (Tijdschrift voor Sociale Gezondheidszorg 1983;61:793-7) 


\section{INLEIDING}

Van galstenen wordt wel gezegd dat het een 'welvaartsziekte' is. Deze uitspraak is gebaseerd op de waargenomen verschillen in het vóorkomen wan een bepaald type galstenen (de cholesterolstenen) tussen Westerse en niet-Westerse landen. Het verbaast dan ook niet dat leefwijzen in de belangstelling staan bij onderzoek naar oorzaken van galstenen.

Inderdaad zijn er aanwijzingen dat bepaalde factoren die samenhangen met leefwijzen, een verhoogde kans op het ontstaan van galstenen met zich meebrengen:

1. De pathofysiologie van galstenen doet vermoeden dat de cholesterolhuishouding betrokken is bij het ontstaan van galstenen. Nu blijkt uit onderzoek naar risicofactoren voor ischemische hartziekte dat leefwijze-gebonden factoren een duidelijke invloed op de cholesterolhuishouding uitoefenen.

2. Er zijn aanwijzingen dat er een positieve associatie bestaat tussen galstenen en ischemische hartziekte, en dat deze associatie gebaseerd is op het bestaan van gemeenschappelijke risicofactoren voor beide ziekten.

3. Etiologisch epidemiologisch onderzoek geeft aanwijzingen voor risicofactoren voor galstenen en ischemische hartziekten. Hiervan komen enkele in aanmerking als gemeenschappelijke risicofactor.

In dit artikel komen we op basis van de beschikbare gegevens tot de volgende hypothese: er is een causaal verband tussen het gehalte van high-density-lipoproteïne (HDL) cholesterol in het serum en het ontstaan van galstenen, in die zin dat bij een verlaggd serum-HDL een verhoogd risico bestaat op galsteenworming. Indien dit zo is, verwachten we dat leefwijze-gebonden factoren die invloed hebben op het serum-HDL, ook een relatie vertonen met galstenen.

In het vervolg wordt deze hypothese uitgewerkt met name voor alcoholgebruik en pilgebruik. Ter illustratie hiervan veronderstellen we dat alcoholgebruik het serum-HDL verhoogt, hetgeen gepaard gaat met een verlaagde kans op galstenen.

De veronderstelde relatie zal nader onderzocht worden door middel van epidemiologisch onderzoek. Het onderzoek is mede van waarde, omdat galstenen veel voorkomen en een grote belasting voor de gezondheidszorg vormen.

\section{EPIDEMIOLOGIE VAN GALSTENEN}

Het is niet mogelijk om de prevalentie van galstenen te schatten door te enqueteren. Veel klachten die wel aan galstenen worden toegeschreven ('dyspepsie'), kunnen veroorzaakt zijn door andere ziekten of vertonen misschien helemaal geen relatie met galstenen $^{1.3}$. Bovendien geven galstenen vaak geen klachten ('stille stenen'). De beste schattingen van de prevalentie komen nog uit onderzoek, waarbij een steekproef uit de bevolking gescreend is met behulp van orale cholecystografie $e^{1,247}$. Beperken we ons tot onderzoek bij blanken in de Westerse wereld, dan bedraagt de prevalentie bij oudere vrouwen ongeveer $10 \%$ en bij jongere vrouwen ongeveer $5 \%$. Hierbij zijn niet gerekend 
de vrouwen, van wie de galblaas in het verleden is werwijderd (meestal met als reden: opspelende stenen). Bij mannen zijn de prevalenties lager. Dergelijk radiologisch screeningsonderzoek is in Nederland nooit uitgevoerd. Wel geeft de prevalentie van galstenen plus cholecystectomie (galblaasoperatie) bij geobduceerden een duidelijke indicatie dat ook in Nederland galstenen veel voorkomen (figuur 1$)^{8}$.

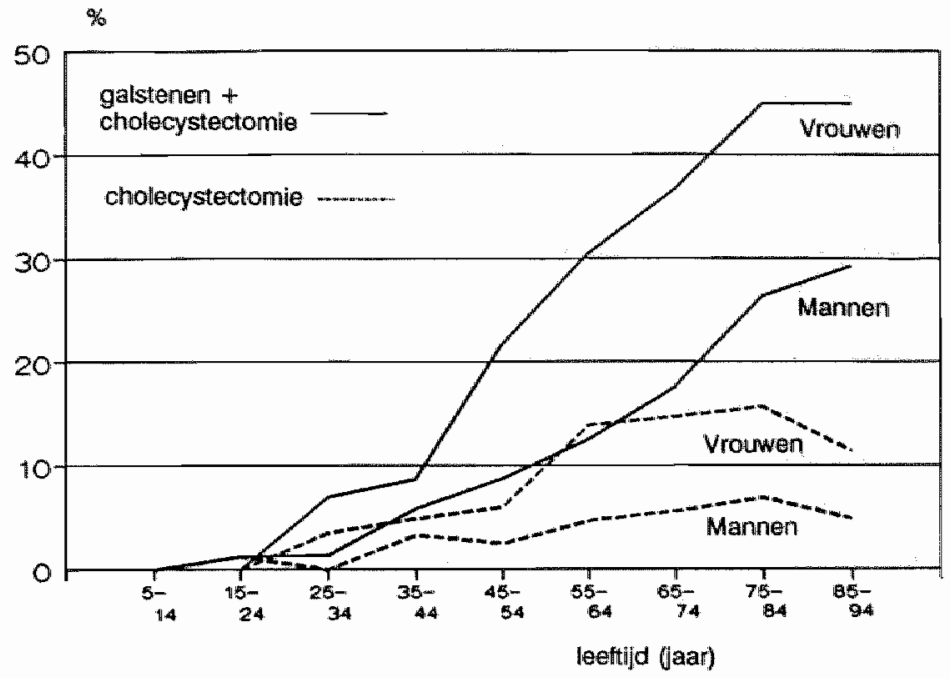

FIGUUR 1 Percentage obducties met galstenen of cholecystectomie, bij peiling in zes steden verspreid over Nederland (1970-1980) $)^{\mathrm{E}}$.

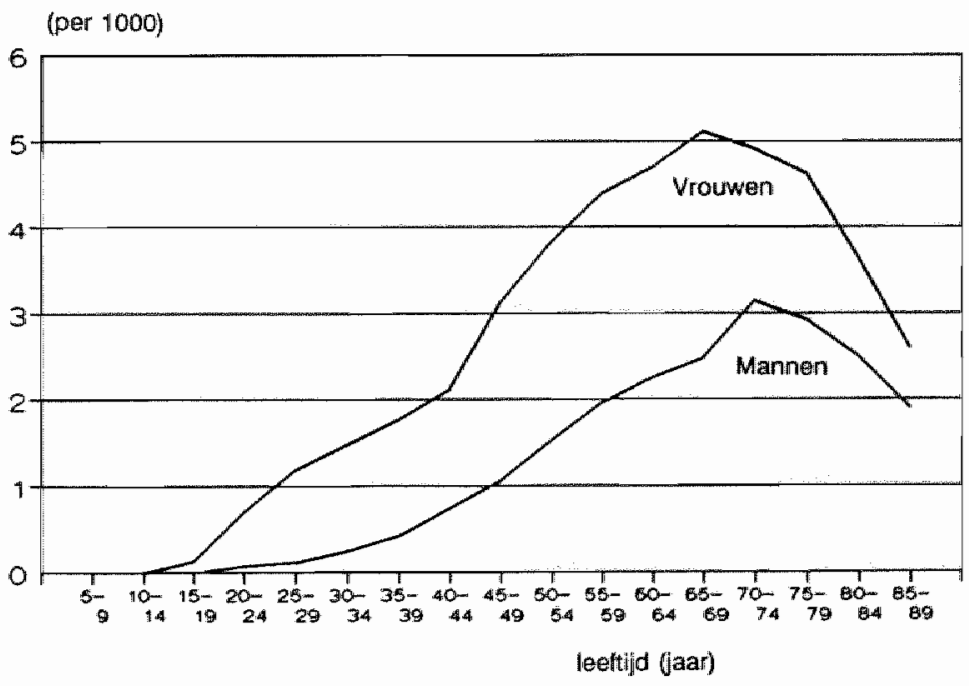

FIGUUR 2 Aantal cholecystectomieën in Nederland in 1979, per 1000 inwoners (bron: SMR). 
Over de incidentie van galstenen is nog minder bekend. Nergens heeft men eenzelfde populatie bij herhaling gescreend. Toch is dat goed mogelijk met de huidige, onschuldige echografie. Als surrogaat geven we daarom de frequentie van cholecystectomie. Deze hangen natuurlijk niet alleen samen met het optreden van galstenen, maar zeker ook met andere factoren, zoals het aanbod van patiënten en de indicatiestelling voor operatie. Volgens opgave van de Stichting Medische Registratie werden in 1979 in Nederland 18.300 cholecystectomieên verricht, waarvan 4.800 bij mannen en 13.500 bij vrouwen. Figuur 2 geeft de incidentie van cholecystectomie apart voor diverse leeftijdsgroepen. Als noemer is daarbij steeds de hele populatie genouen, dus inclusief de mensen zonder galblaas. Het valt nu ook op dat cholecystectomie veel meer bij vrouwen dan bij mannen voorkomt; over alle leeftijdsgroepen samen bij vrouwen 1,9 en bij mannen 0,7 per 1000 .

Voor etiologisch onderzoek is het van belang om onderscheid te maken naar soort galsteen. In bepaalde Afrikaanse en Aziatische landen lijken galstenen maar heel weinig voor te komen" en dan betreft het meestal pigmentstenen, stenen met minder dan $10 \%$ cholesterol in de steen. In landen' als Nederland heeft naar schatting hoogstens een kwart van alle galsteendragers pigmentstenen. Meestal gaat het hier om cholesterolstenen, waarbij de hoeveelheid cholesterol per steen nog wel kan variëren. Als deze stenen voor minder dan driekwart uit cholesterol bestaan, wordt ook wel gesproken van 'gemengde stenen" ${ }^{\prime 10}$. Er wordt gesuggereerd dat deze galstenen nu veel meer vóórkomen dan bijvoorbeeld in de eerste helft van deze eeuw", maar het bijbehorende cijfermateriaal (obductiecijfers) is nogal zwak.

De ontstaansmechanismen van cholesterolstenen en pigmentstenen zijn zeer verschillend. In veel epidemiologisch onderzoek dat in Westerse landen plaatsvindt, wordt geen onderscheid gemaakt tussen de verschillende soorten galstenen. Over het algemeen worden dus risicofactoren opgespoord die vooral betrekking hebben op cholestero]stenen. Van enkele van deze risicofactoren zijn ook verbanden gelegd met het pathogenetisch mechanisme. Tabel 1 geeft een overzicht van de tot nu toe bekende risicofactoren, mede ontleend aan het uitstekende literatuuroverzicht van Cohen ${ }^{12}$ en het artikel van Bennion en Grundy ${ }^{13}$.

\section{PATHOGENESE VAN GALSTENEN}

Centraal bij het ontstaan van cholesterolstenen staat de verzadigingsgraad van de gal met cholesterol. De lever scheidt cholesterol, galzouten en fosfolipiden (vooral lecithine) uit in de gal. De verhouding tussen deze stoffen bepaalt de galverzadiging. Cholesterol slaat bij oververzadiging neer in de vorm van kristallen; galzouten en -in mindere matelecithine hebben het vermogen cholesterol in oplossing te houden door de vorming van micellen. Zo wordt bij mensen met vetzucht, bij wie galstenen vaker voorkomen, een hogere secretie van cholesterol gevonden, onvoldoende gecompenseerd door de eveneens verhoogde galzoutsecretie. De galzouten worden door de lever uit het cholesterol gesynthetiseerd om het verlies van galzouten uit de enterohepatische cyclus te compenseren. Normaal overtreft dit vermogen tot synthese het feitelijk verlies vele malen. 
Figuur 3 geeft een schematisch overzicht van factoren die het neerslaan van cholesterol uit onverzadigde gal en de verdere groei van galstenen kunnen beïnvloeden. Mogelijk zijn deze factoren ook betrokken bij de vorming van pigmentstenen ${ }^{14}$; oververzadiging van gal met cholesterol speelt hierbij echter geen rol $^{\text {ts }}$.

TABEL 1 Pisicofactoren voor galstenen

\begin{tabular}{|c|c|c|c|}
\hline & Zeker & Waarschijnijik & Mogelijk \\
\hline $\begin{array}{l}\text { CHOLESTEROL- } \\
\text { STENEN }\end{array}$ & $\begin{array}{l}\text { leeftijd } \\
\text { vrouwelijk geslacht } \\
\text { vetzucht } \\
\text { exogene oestrogenen }\end{array}$ & $\begin{array}{l}\text { excessief galzoutverlies: } \\
\text { ileumresectie of -ziekte } \\
\text { cholestyramine } \\
\text { pilgebruik } \\
\text { pariteit } \\
\text { hypentriglyceridemie } \\
\text { cholesterolverlagende } \\
\text { medicatie }\end{array}$ & $\begin{array}{l}\text { voeding: } \\
\text { cholesterolverlagend } \\
\text { calorierijk } \\
\text { suikerrijk } \\
\text { vezelarm } \\
\text { niet-ontbijten, vasten } \\
\text { alcoholgeheelonthouding } \\
\text { roken } \\
\text { weinig lichaamsbeweging } \\
\text { snelle gewichtsreductie } \\
\text { laag HDL-cholesterol } \\
\text { hartinfarkt } \\
\text { suikerziekte }\end{array}$ \\
\hline
\end{tabular}

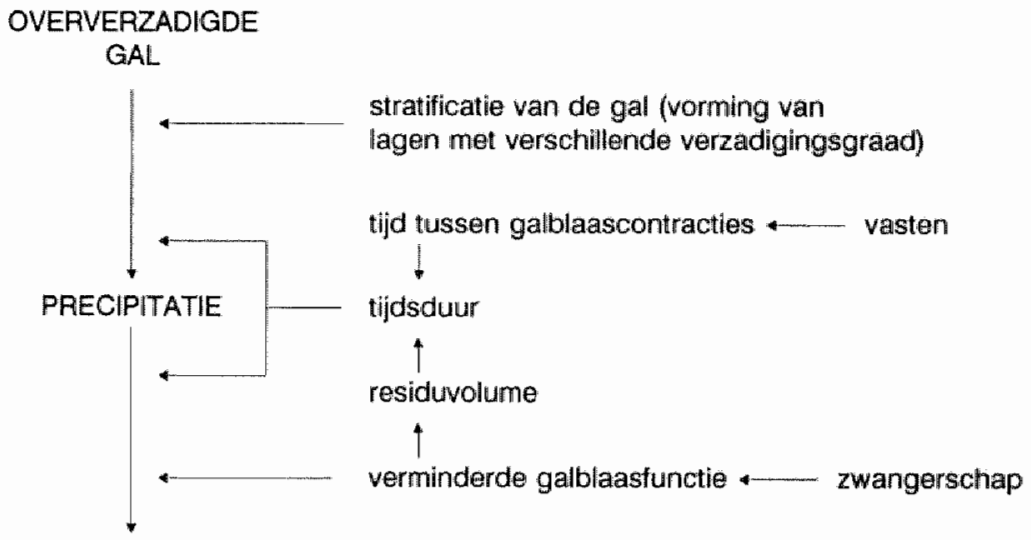

GALSTEEN

FIGUUR 3 Schematische weergave van het ontstaan van galstenen uit oververzadigde gal. 


\section{Galstenen en cholesterolhuishouding}

Zowel cholesterol in de gal als de galzouten zijn afkomstig van cholesterol in de lever. Het is te verwachten dat de verhouding tussen beide ook op dit niveau gereguleerd wordt. Dit cholesterol in de lever is potentieel afkomstig uit twee bronnen: de novo synthese in de lever en aanvoer uit de perifere weefsels. Bij dit transport wordt een bepaalde lipoproteine-fractie, het high-density-lipoprotein (HDL) geacht een belangrijke rol te spelen. Van cholesterol in de gal is geen functie bekend, en cholesterol in het menselijk lichaam kan niet verder worden gemetaboliseerd, met uitzondering van omzetting in galzouten en -in zeer kleine hoeveelheden- steroidhormonen. Dit suggereert dat het menselijk lichaam zich via de galwegen van een overtollig produkt ontdoet. Overigens wordt cholesterol ook in de lever zelf gesynthetiseerd.

De hypothese van verhoogde galverzadiging bij verhoogde afvoer van cholesterol wordt ondersteund door de volgende bevindingen. Ten eerste verhoogt clofibraat, een cholesterolverlagend geneesmiddel, het risico op galstenen ${ }^{\text {th }}$. Ten tweede geldt dit mogelijk ook voor cholesterolverlagend dieet: in een gerandomiseerde trial bij geïnstitutionaliseerde mannen in de VS waarbij het effect van een cholesterolverlagend dieet werd vergeleken met een normaal Amerikaans dieet, bleek dat mannen met het eerstgenoemde dieet vaker galstenen hadden bij obductie ${ }^{17}$. Dit kon overigens in een soortgelijk onderzoek in Finland niet kon worden bevestigd ${ }^{18}$. Bij pogingen om het vóórkomen van galstenen te relateren aan de cholesterolhuishouding kon geen verband met serumcholesterol worden aangetoond ${ }^{19}$. Nu is het serumcholesterol geen goede indicator van de balans tussen opname in de darm en synthese van cholesterol enerzijds, en transport naar de lever en uitscheiding anderzijds. Meer informatie hierover geven de serum-lipoproteïnefracties. Inderdaad lijkt bij galsteenpatiënten relatief vaak een afwijkende lipoproteïnehuishouding voor te komen, te weten hyperlipoproteïnemie type IIb en IV ${ }^{20}$. Voorzover HDL-cholesterol een indicator is van afvoer van cholesterol uit perifere weefsels naar de lever, verwachten we dat galstenen vaker zullen optreden bij een hoger serum-HDL-cholesterol.

Tegen deze verwachting is echter een omgekeerd verband gevonden. In een onderzoek bij vrouwen werd gevonden dat vrouwen met een laag HDL-cholesterol méér gálblaasziekte rapporteerden dan vrouwen met een hoog HDL-cholesterol (tabel 2) ${ }^{21}$. Een aanwijzing dat er hier sprake is van een causaal verband, geeft het onderzoek van Thornton ${ }^{22}$. Bij 25 gezonde vrijwilligsters werd de serumlipoproteïnefracties en de verzadiging van de gal, afgenomen per duodenaalsondage bepaald. Bij een hogere galverzadiging werden leigere HDL-cholesterolwaarden gevonden (tabe] 3). Dit omgekeerde verband tussen HDL-cholesterol en de galverzadiging suggereert dat het cholesterol dat door HDL naar de lever wordt getransporteerd, niet zonder meer als zodanig in de gal terecht komt, maar bij voorkeur in galzouten wordt omgezet.

De vraag doet zich nu voor, of factoren die het HDL-cholesterolgehalte in het bloed veranderen, ook het ontstaan van galstenen beïnvloeden, zoals dit ook wordt verondersteld bij het ontstaan van coronaire hartziekte. Het bestaan van een associatie tussen galstenen en coronaire hartziekte zou hiervoor een indirecte aanwijzing geven. 
TABEL 2 Percentage vrouwen met een voorgeschiedenis van gallblaasziakte naar kwartil van serum-HDL-cholesterol (bron: Petitti 1981"

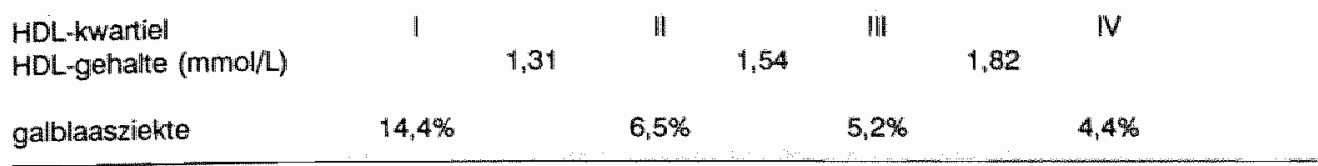

TABEL 3 Serum-HDL-cholesterolgehalte wan 25 gezonde vrijwilligsters, uitgespitst naar al-of-niet oververzadigde gal* (bron: Thornton ${ }^{22}$ )

gall oververzadigd:

ja $(n=18)$

nee $(n=7)$

HDL gemidideld (mmol/L)

1,51

1,80

(standaardafwijking)

$(0,21)$

$\left(\mathrm{O}_{\mathrm{n}} 30\right)$

- Gialverzadigingsindex $>1$ respectievelijik $\leq 1$.

\section{RISICOFACTOREN VOOR GALSTEENZIEKTE}

De relatie galstenen/hartinfarkt

In de oudere literatuur wordt herhaaldelijk gewezen op een associatie tussen galstenen en coronaire hartziekte. Friedman onderwierp deze onderzoeken aan een kritische analyse, en kwam tot de conclusie dat de associatie in ieder geval niet sterk is ${ }^{23}$. Bovendien miste hij een goede verklaring, hoewel vetzucht als gezamenlijk risicofactor een zwakke associatie nog wel zou kunnen verklaren.

Recent gecontroleerd onderzoek heeft sterkere aanwijzingen gegeven voor een associatie tussen galsteenlijden en coronaire hartziekte. In het kader van de Walnut Creek Contraceptive Drug Study werden ruim 16.000 vrouwen na een medisch onderzoek gedurende ruim zes jaar gevolgd. Met behulp van een patiënt-controle onderzoek binnen deze groep kon worden aangetoond dat vrouwen met een galblaasziekte in de anamnese een zesmaal zo grote kans hadden op een hartinfarkt dan vrouwen zonder galblaasvoorgeschiedenis. Bij multivariate analyse, met als variabelen roken, alcoholgebruik, hypertensie, hypercholesterolemie en vetzucht, werd dit relatieve risico zwakker. Dit suggereert dat het effect althans gedeeltelijk toe te schrijven is aan een of meer gemeenschappelijke risicofactoren of daarmee samenhangende, onderliggende oorzaken ${ }^{24}$.

\section{Alcoholgebruik en galstenen}

Verder vinden we aanwijzingen voor een gezamenlijke risicofactor voor galsteenlijden en coronaire hartziekte in een onderzoek van Klatsky ${ }^{23}$. In het kader van ziektekostenverzekering in de V.S. werden bij een groot aantal personen gegevens verżameld, onder andere over alcohol-consumptie. Deze gegevens konden worden gekoppeld aan ziekenhuisopnamen. 2015 Personen die 6 glazen of meer per dag dronken, werden gematcht op leeftijd, geslacht en al-of-niet roken met personen die respectievelijk 0,2 of minder, en 3 
tot en met 5 glazen per dag dronken. Voor de meeste diagnosen gold dat de zwaarste drinkers $(6+)$ vaker werden opgenomen, behalve woor coronaire hartziekte, acuut hartinfarkt, prostaathyperplasie en galstenen. Het hoogste risico te worden opgenomen voor galstenen liepen geheelonthouders, en het risico nam af met de toename van de alcoholconsumptie (tabel 4).

TABEL 4 Incidentie (\%) van ziekenhuisopnamen in zes jaar (1971-1976) wegens galstenen (cholelithiasis) en coronaire hartziekte, naar alcoholinname (bron: Klatsky 198125)

\begin{tabular}{llllll}
\hline & & \multicolumn{5}{c}{ Alcoholinname (glazen per dag) } \\
& & 0 & 52 & $3-5$ & 26 \\
\hline \multirow{2}{*}{ Galstenen } & mannen & 1,3 & 0,8 & 1,0 & 0,5 \\
& vrouwen & 3,7 & 2,0 & 0,0 & 1,7 \\
& totaal & 1,9 & 1,0 & 0,8 & 0,7 \\
Coronaire hartziekte & mannen & 9,3 & 6,4 & 6,9 & 6,8 \\
& vrouwen & 3,6 & 3,9 & 2,0 & 1,4 \\
& totaal & 8,0 & 5,9 & 5,8 & 5,6 \\
\hline
\end{tabular}

Hiermee zijn we dan een risicofactor op het spoor gekomen die consistent is met de hypothese dat er een causaal, negatief verband bestat tussen galstenen en HDLcholesterol. Alcoholgebruik verhoogt naar alle waarschijnlijkheid het serum-HDL ${ }^{26}$ en dit geeft mogelijk een verminderde kans op galsteenvorming. Iets dergelijks is aannemelijk gemakt voor het negatieve verband tussen alcohol en hartinfarkt dat ook (onder andere) uit het $\mathrm{HDL}$ verklaard wordt ${ }^{27}$. Aldus is tevens een verklaring gegeven voor een zwakke associatie tussen galstenen en hartinfarkt.

\section{HDL, leefwijze en galstenen}

Veronderstellen we nu een oorzakelijk verband tussen HDL en het ontstaan van galstenen, dan mogen we verwachten dlat ook andere factoren dan alcoholgebruik die van invloed zijn op het $\mathrm{HDL}^{28}$, het ontstaan van galstenen beïnvloeden. De factoren die met deze gedachtengang in overeenstemming of in tegenspraak zijn, zijn opgesomd in tabel 5 . Voor pilgebruik is hierover geen duidelijke uitspraak te doen, omdat de invloed op HDL. afhankelijk lijkt te zijn van de samenstelling van de pil"

Overigens staat een verhoogd risico op galstenen bij pilgebruik niet onomstotelijk vast. In een patiënt-controle onderzoek een relatief risico gevonden van 2.0 voor pilgebruiksters ten opzichte van niet-pilgebruiksters ${ }^{30}$. Resultaten van een groot cohort onderzoek doen echter twijfelen aan een verhoogd risico op langere termijn ${ }^{31}$. Bij weergave van de incidentie naar de duur van het pilgebruik (figuur 4) blijkt het risico van pilgebruik voor gatblaasziekte de eerste jaren verhoogd te zijn, maar na langere blootstelling weer af te nemen. 
Samenvattend kunnen we stellen dat er t.a.v. diverse leefwijze-afhankelijke factoren aanwijzingen zijn voor een invloed op het ontstaan van galstenen, en dat beïnvloeding van de serum-lipoproteïnefracties hierbij mogelijk een rol spelen.

TABEL 5 Factoren van invloed op HDL die consistent of inconsistent zijn met de hypothese "factor $-\mathrm{HDL} \rightarrow$ galstenen" (factor verhoogt $(+)$ of verlaagt $(-)$ het $\mathrm{HDL}$ )

\begin{tabular}{lcl}
\hline Consistent & \multicolumn{3}{l}{ Inconsistent } \\
\hline alcoholgebruik & + & leeftijd \\
roken & - & vrouwelijk geslacht + \\
suikerinname & - & exogene oestrogenen + \\
vetzucht & - & \\
lichaamsbeweging & + & \\
\hline
\end{tabular}

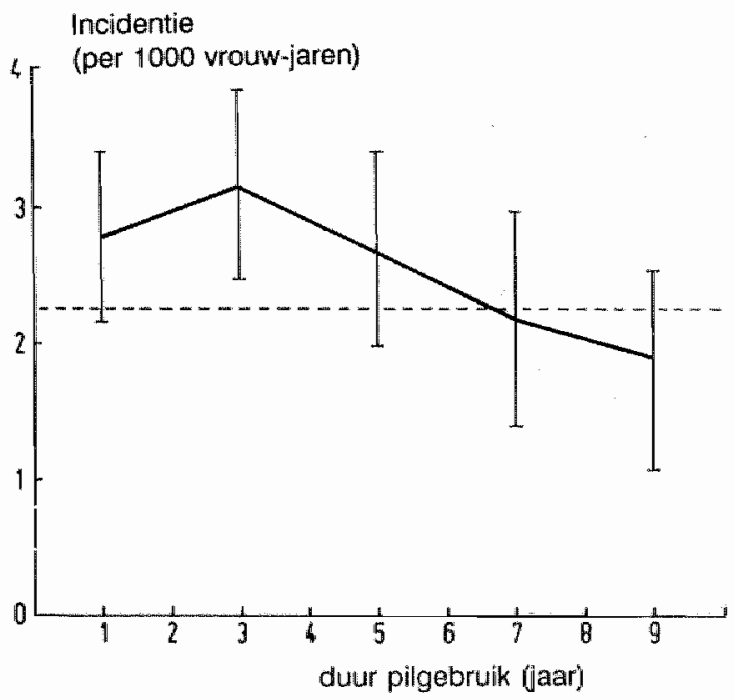

FIGUUR 4 Incidentie van galbiaasziekte naar de duur van pilgebruilk, per 1000 vrouw-jaren (met $95 \%$ betrouwbaarheidsintervallen), gestandaardiseerd naar leeftijd, roken en pariteit. De horizontale lijn geeft de incidentie weer in de controlegroep van niet-pilgebruiksters (Royal College of General Practitioners' Oral Contraception Study, 198:2").

\section{Verder onderzoek}

Teneinde meer inzicht te krijgen in de relatie tussen leefwijze en galsteenlijden hebben we een patiënt-controle onderzoek gepland. Hierbij willen we onze aandacht vooral richten op pilgebruik en alcoholgebruik als mogelijke risicofactoren voor galstenen, waarbij tevens de relatie met HDL-cholesterol zal worden bestudeerd. In twee jaar tijd 
worden in ziekenhuis St. Arnadal te Maastricht ongeveer 300 patiënten opgenomen voor een galblaasoperatie. Controlegroepen zullen bestaat uit patiënten die tezelfdertijd het ziekenhuis bezoeken in verband met ziekten die naar alle waarschijnlijkheid niets met de te bestuderen risicofactoren te maken hebben. We denken aan spataderen, aambeien, perianaal abces en carpale tunnel-syndroom.

Bij patiënten dienen cholesterolstenen van pigmentstenen te worden onderscheiden; bij controle-patiënten dienen galstenen te worden uitgesloten (echografie). Bij beide groepen zullen de serumlipoproteïnefracties worden bepaald, en wordt de expositie aan potentiële risicofactoren bepaald met behulp van een vragenlijst. De vragenlijst zal ook worden afgenomen bij een steekproef uit de bevolking van het verzorgingsgebied van eerder genoemd ziekenhuis.

ABSTRACT - There are indications that alcohol consumption protects against gallstone disease and that a low serum HDL cholesterol is associated with an increased risk of gallstones. Because alcohol raises serum high-density-lipoprotein (HDL), we hypothesize that the possible protective effect of alcohol use on gallstone development is mediated by changes in serum HDL. If so, we expect that other factors determining HDL (pill use, physical exercise. smoking) also have an influence on the development of gallstones. In order to investigate possible life style risk factors of gallstones and to determine the role of HDL we have planned a case-control study.

\section{REFERENTIES}

1. Wilbur RS, Bolt RJ. Incidence of gallbladder disease in "normal' men. Gastroenterology 1959;36:251-5.

2. Price WH. Gallbladder dyspepsia. Brit Med J 1963;2:138-41.

3. Koch JP, Donaldson Jr RM. A survey of food intolerances in hospitalized patients. $N$ Engl $J$ Med $1964 ; 271: 657-60$.

4. Sampliner RE, Bennett PH, Comess LJ. Gallbladder disease in Pima indians: demonstration of high prevalence and early onset by cholecystography. N Eng J Med 1970;283:1358-64.

5. Bainton D, Davies GT, Evans $K$, Gravelle $\mathrm{IH}$. Gallbladder diseasc; prevalence in a South Wales industrial town. N Engl I Med 1976;294:1 147-9.

6. Sarles $\mathrm{H}$, Gerolami $\mathrm{A}$, Bord A. Diet and cholesterol gallstones; a further study. Digestion 1987;17:12834.

7. Tsuchiyia $\mathrm{Y}$. Oral gallstones dissolution therapy of asymptomatic gallstones and their indication for surgery. Gastroenterology Japonica 1979; 14:633-4.

8. Flekken P, Knipschild P. Galstenen en kanker van de galblaas. Werkrapport Capaciteitsgroep Epidemiologien. Masstricht: Rijksuniversiteit Limburg, 1982.

9. Bretc M, Barker DJP. The world distribution of gallstones. Int J Epidemiol 1976;5:335-41.

10. Bennion Lal, Grundy SM. Risk factors for the development of cholethiasis in man. I. N Engl J Med $1978 ; 299: 1161-7$

11. Bateson $\mathrm{MC}_{4}$ Bouchier IAD. Prevalence of gallstones in Dundee: a necropsy study. Brit Med J $1975 ; 4: 427-30$.

12. Cohen MM. Chronic disease reviews no. 1: Gallstones. Chronic Dis Canada 1982;3(no. 2 suppl).

13. Bennion $\mathrm{LJ}$, Grundy SM. Risk factors tor the development of cholelithiasis in man. II. N Engl J Med $1978: 299: 1221-7$.

14. Soloway RD, Trotman BW, Ostrow JD. Pigment gallstones. Gastroenterology 1977;72:167-82. 
15. Trotman BW, Ostrow JD, Soloway D. Pigment ws. cholesterol cholelithiasis: comparison of stone and bile composition. Dig Dis 1974;19:585-90.

16. Cooper J. Geizerova H, Oliver MF. Clofibrate and gallstones, Lancet 1971;2:1083.

17. Sturdevant RAL, Pearce ML, Daylon $S$. Increased prevalence of cholelithiasts in men ingesting a serum-cholesterol-lowering diet. N Engl J Med 1973;288:24-7.

18. Miettinen $M$, Turpeinen $O$, Karwonen $M J$, at all. Prevalence of cholelithiases in men and women ingesting a serum-cholesterol-lowering diet. Ann Clin Res $1976 ; 8: 111-6$.

19. Friedman GD, Kannel WB, Dawber TR. The epideniology of gallbladder disease: obserwations in the Framingham Study. J Chron Dis 1966;19:273-92

20. Ahlberg J. Biliary metabolism in hyperlipoproteinemia and gallstone disease. Acta Chir Scand $1979 ; 492$ (suppl): $:-32$.

21. Petiti DB, Friedman GD, Klatsky AL. Association of a history of gallbladder disease with a reduced concentration of high-density-lippoprotein cholesterol. N Engl J Med 1981;304:1396-8.

22. Thornton JR, Heaton KW, MacFarlane DG. A relation between high-density-lipoprotein cholesterol and bile cholesterol saturation. Brit Med J 1981:383:1352-4.

23. Friedman GD. The relation between coronary heart disease and gallbladder disease - a critical review. Ann Int Med 1968;68:222-35.

24. Petitti $\mathbb{D B}_{2}$ Wingerd J, Pellegrin $F$, Ramcharan $S$. Risk of vascular disease in women. JAMA 1979;242:1150-4.

25. Klatsky AL, Friedman GD, Siegelaub AB. Alcohol use and cardiovascular disease: the Kaiser Permanente experience. Circulation 1981;64(suppll 13):32-41..

26. Castelli WP, Doyle JT, Gordon $T$, et al. Alcohol and blood lipids. Lancet 1977;2:153-5.

27. Knipschild P. Alcohol als hartversterker. Hart Bulletin 1982;13:24-32.

28. Heiss $G$, Johnson $N J$, Reiland $N$, et all. The epidemiology of plasma high-density-lipoprotein cholesterol Ievels. Circulation 1980;62(suppi):116-36.

29. Bradley DD, Wingerd $J$, Petiti DB, et al. Serum high-densily-lipoprotein cholesterol in women using oral contraceptives, estrogens and progestives. N Engl J Med 1978;299:17.20.

30. Boston Collaborative Drug Surveillance Programme. Oral contraceptives and vemous thromboembolic disease, surgically confirmed gallbladder disease, and breast tumours. Lancet $1973 ; \mathrm{i}: 1399$-1404.

31. Royal College of General Practitioners" Oral Contraception Study. Oral contraceptives and gallbladder disease. Lancet 1982;ii:957-9. 



\title{
HDL-CHOLESTEROL
}

\author{
Serumlipiden en galsteenrisico \\ - een patiënt-controle onderzoek
}

De rol van serumlipiden in de etiologie van galstenen werd geẻvalueerd in een patiëntcontrole onderzoek. Het onderzoek omvatte 250 patienten met chirurgisch of echografisch bevestigde galblaasstenen, en 526 ziekenhuispatiënten als controlegroep.

Het hoogste galsteenrisico werd gevonden bij een laag serumgehalte aan high-density lipoproteïne cholesterol en een hoog triglyceridengehalte. Een additioneel zwak omgekeerd verband werd gevonden tussen totaal serumcholesterol en galsteenrisico. De bevindingen waren ongeveer gelijk voor cholesterolstenen en pigmentstenen.

Het verband tussen vetzucht (uitgedrukt als Quetelet-index) en het galsteenrisico verdween bij controle voor serumlipiden in een multivariate analyse.

Dit onderzoek bevestigt eerdere publicaties over het verband tussen serumlipiden en galstenen. De gelijkenis van cholesterolstenen en pigmentstenen wat betreft hun relatie met serumlipiden suggereert dat deze typen galstenen meer oorzakelike factoren gemeen hebben dan voorheen werd verondersteld. De afwezigheid van een effect van de Quetelet-index onafhankelijk van serumlipiden (zoals aangetoond in de multivariate analyse) suggereert dat serumlipiden dichter bij het pathogenetisch mechanisme staan dan vetzucht. 


\title{
SERUM LIPIDS AND GALLSTONES \\ - A CASE-CONTROL STUDY
}

\author{
Carel Thijs, Paul Knipschild and Paul Brombacher
}

Department of Epidemiology/ Health Care Research

and Department of Biochemistry, Rijksuniversiteit Limburg, The Netherlands

ABSTRACT - The role of serum lipids in the etiology of cholesterol gallstones and pigment gallstones was assessed in a case-control study. The study included 250 cases with surgically or ultrasonographically confirmed cholecystolithiasis and 526 hospital control patients. The highest gallstone risk was found at low high-density cholesterol levels and high triglyceride levels. An additional weakly negative association was faund between total cholesterol level and gallstone risk. These findings were similar for cholesterol gallstones and pigment gallstones. The association between body mass index and gallstone risk disappeared after adjusiment for serum lipids in a multivariate analysis. This study confirms previous reports on the association between gallstone risk and serum lipids. The similarity between cholesterol and pigment gallstones with regard to their association with serum lipids indicates that these types of gallsiones share more causal factors than previously suggested. The absence of an effect of body mass index independent from serum lipids (as shown by the multivariate analysis) suggests that serum lipids are more closely linked to the pathogenesis of gallstones than obesily. (Gastroenterology 1990;99:843-49, copyright 1990 by the American Gastroenterological Association).

\section{INTRODUCTION}

In affluent societies, most gallstones are composed primarily of cholesterol. Therefore, research of the etiology of gallstones has for long focused on the role of cholesterol metabolism in the pathogenesis of gallstones. A key role is usually assigned to the cholesterol saturation of biliary bile, as determined by the balance between the concentrations of cholesterol and its solubilizers, especially bile salts.

Researchers seeking to link the pathogenetic role of biliary cholesterol with risk factors for gallstones have published data about the relation between serum cholesterol levels and the occurrence of gallstones ${ }^{10}$, as well as data about the effect of dietary cholesterol intake on bile cholesterol saturation ${ }^{\text {1h.t. }}$. Their results do not support the idea that serum cholesterol or dietary cholesterol intake are important determinants of 
gallstone risk. This view is confirmed by a failure to detect any effect of common variations in dietary cholesterol intake on gallstone risk in epidemiological studies ${ }^{2.35}$.

Instead, a pathogenetic mechanism for the effect of potential risk factors should perhaps be sought in the role of serum lipoproteins and triglyceride. High-density lipoprotein (HDL) cholesterol has been reported to be negatively associated with previous gallbladder disease or the presence of gallstones ${ }^{8.56}$. A negative correlation between HDL cholesterol levels and bile cholesterol saturation has also been demonstrated ${ }^{17,18}$. Serum triglyceride levels were found to be positively associated with

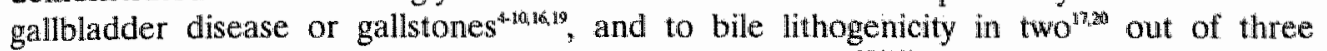
studies $^{17,1820}$. Results of studies on hyperlipoproteinemias $s^{5,721,12}$ are consistent with these findings.

As far as we are aware, earlier investigations on the association between serum lipids and gallstones have made no distinction between cholesterol and pigment stones. The results of these studies can be assumed to be valid for cholesterol gallstones, because of the preponderance of such stones in the populations studied.

The present report of a case-control study of the etiology of gallstones in Maastricht focuses on a possible causal relation between serum lipid levels and gallstones. In addition, attention is paid to the following issues: (1) the extent to which pigment gallstone disease differs from cholesterol gallstone disease with respect to the association with serum lipids and (2) the extent to which the association between body mass and gallstones can be explained by serum lipids.

\section{MATERIALS AND METHODS}

\section{Subjects}

A hospital-based case-control study was performed at Academic Hospital Maastricht. Over a 2-year period from 1983 to 1985 , subjects were entered into the study if they met the following admission criteria: they were white men aged 30 to 76 years or women aged 20 to 76 years, resided in the province of Limburg, and had an intact gallbladder. There were two series of cases. Radiology cases were a consecutive series of new patients, referred to the Department of Radiology for ultrasound or X-ray examination. of the gallbladder, in whom gallstones were detected. Surgery cases were a consecutive series of cholecystectomy patients admitted for operation. The existence of gallstones in the gallbladder was ascertained during operation in all operated cases from both series.

There were also two control series. Radiology controls were a concurrent sample of patients, from the same roster of teferrals to the Department of Radiology for ultrasound or X-ray examination of the gallbladder, in whom gallstones were ruled out. Surgery control patients were a concurrent consecutive series of patients admitted for elective surgery, from the same roster of admissions which was the source of the surgery cases. This included a consecutive series of patients operated on for hemorrhoids varicose veins or carpal tunnel syndrome, and a sample of patients operated for inguinal hernia or osteoarthritis of the hip. Surgery controls were screened by ultrasound examination to rule out gallstones. 


\section{Measurements}

Blood was taken by venipuncture from fasting subjects. In radiology cases and control patients, it was done shortly betore their gallbladder examination, in surgery case and control patients it was done on the morning before the operation. Blood was centrifuged within four hours, and the serum was stored at $-20^{\circ} \mathrm{C}$ for 1 week to 3 months, in a similar way for case and controls patients. Serum HDL was obtained by precipitation of very low-density and low-density lipoproteins with phosphotungstate- $\mathrm{Mg}_{2+}$. High-density lipoprotein cholesterol and total cholesterol were measured by the CHOD-PAP method. 25 Triglyceride was measured by an automated enzymatic method. The percentage of cholesterol in powdered dried gallstones was measured in a series of cholecystectomized patients.

\section{Analysis}

Two measures of association were assessed:

1. Mean serum lipid levels in cases were compared with the levels that were expected if the cases had lipid levels similar to those of the control patients. These expected mean levels were computed from the levels in controls by standardization for age, using the age distribution of the cases as the standard. The difference between the observed and expected levels (and its 95\% confidence limits, CL-95\%) was expressed as a percentage of the expected mean levels (relative mean difference, MD\%). This was done separately for men and women. For reasons of efficiency, the results were combined in the analysis of subgroups, and precision- maximizing weighing was used to standardize for age and $\operatorname{sex}^{24}$.

2. The odds of having gallstones as a function of serum lipid levels were studied by multivariate logistic regression analysis ${ }^{25}$, controlling for age and sex. In the context of risk factors the resulting odds ratios (OR) are estimates of relative risks. Odds ratios (with their CL-95\%) can be derived by taking the natural antilog of the regression coefficients (plus or minus 1.96 times their standard errors). Multicollinearity was assessed by computation of Eigen values from the data matrix ${ }^{26}$.

Gallstones were classified as cholesterol or pigment gallstones, according to the percentage of cholesterol in analyzed gallstones. Criteria were derived from the distribution of the percentage of cholesterol in visually classified gallstones as described by Trotman et al. ${ }^{272}$. The upper limit for the percentage of cholesterol in pigment stones was taken at $25 \%$ and the lower limit for cholesterol stones at $60 \%$.

\section{RESULTS}

Table 1 shows the non-response rates and the number of participants and case and control patients. After exclusions, data on 776 subjects were availlable for analysis. Ultrasound screening of the surgery patients indicated that 27 of them (11 men and 16 women) had gallstones. These patients were included in the group of cases. In all, there were 250 cases ( 74 men and 176 women) and 526 control subjects (211 men and 315 women). 


\begin{tabular}{|c|c|c|c|c|c|}
\hline & & $\begin{array}{l}\text { Radiology } \\
\text { patients }\end{array}$ & $\begin{array}{l}\text { Cholecyst- } \\
\text { ectomy } \\
\text { patients }\end{array}$ & $\begin{array}{l}\text { Surgery } \\
\text { patients }\end{array}$ & Total \\
\hline \multicolumn{2}{|c|}{ Non-response rate $(\%)$} & 18 & 13 & 28 & \\
\hline \multicolumn{2}{|c|}{ No. of participants } & 224 & 177 & 411 & 812 \\
\hline \multicolumn{6}{|c|}{ Exclusions } \\
\hline \multicolumn{2}{|c|}{ Previous cholecystectomy } & 1 & - & 16 & 17 \\
\hline \multicolumn{2}{|c|}{ Inconclusive gallstone status } & 10 & 4 & 4 & 18 \\
\hline \multicolumn{2}{|c|}{ Serum lipid analysis missing } & - & 1 & $\dot{-}$ & 1 \\
\hline \multicolumn{2}{|c|}{ Remaining } & 213 & 172 & 391 & 776 \\
\hline \multirow{2}{*}{ Men } & cases & 14 & 49 & 11 & 74 \\
\hline & controls & 42 & - & 169 & 211 \\
\hline \multirow{2}{*}{ Women } & cases & 37 & 123 & 16 & 176 \\
\hline & controls & 120 & - & 195 & 315 \\
\hline
\end{tabular}

The breakdown of surgery patients according to admission diagnoses was as follows: carpal tunnel syndrome, 18 men and 82 women; inguinal hernia, 104 men and 11 women; hemorrhoids, 29 men and 19 women; varicose veins, 29 men and 93 women and osteoarthrosis of the hip, 6 women. Mean age of the case patients was 59 years for men and 53 years for women; for the control patients, it was 52 and 47 years, respectively.

Serum total cholesterol levels were slightly lower in gallstone cases than expected on the basis of the levels in controls (table 2). The levels of HDL cholesterol levels were lower and levels of triglyceride higher than expected. In this analysis, one outlier was excluded from the female controll group. She was a woman with gross hypercholesterolemia and hypertriglyceridemia. When her data were included, the results were similar for total and HDL cholesterol, whereas for triglyceride the MD\% for the women was $+20 \%$ ( $95 \%$ confidence interval $+2 \%$ to $+38 \%$ ). This outlier remains excluded in the computation of mean serum lipid levels which follows.

TABLE 2 Mean serum lipid levels (mmol/L) observed and expected in gallstone cases and the relative mean differences (MD\%) with their 95\% confidence limits (CL-95\%)

\begin{tabular}{|c|c|c|c|c|c|c|}
\hline & \multicolumn{3}{|c|}{ Men } & \multicolumn{3}{|c|}{ Women } \\
\hline & Observed & Expected & MD\% (CL-95\%) & Observed & Expected & d MD\% (CL-95\%) \\
\hline Total cholestero: & 5.60 & 6.13 & $-9 \%(-13,-4)$ & 5.91 & 6.14 & $-4 \%(-7,-1)$ \\
\hline HDL-chalesterol & 0.84 & 1.04 & $-19 \%(-26,-13)$ & 1.08 & 1,26 & $-14 \%(-19-11)$ \\
\hline Triglyceride & 2.24 & 1.85 & $+21 \%(+4,+38)$ & 1.70 & 1.35 & $+26 \%(+15+38)$ \\
\hline
\end{tabular}

NOTE. Corversion tactors for mean serum lipid levels from mmol/L to $\mathrm{mg} / \mathrm{dL}$ are 38.7 for total and HDL cholesterol: 88.6 10 r triglycenide. 
The correlations between the variables were not strong enough to cause multicollinearity problems in the multivariate logistic regression analysis. The above-mentioned outlier fit in well with all models; therefore, there was no reason to exclude her from the logistic regression analyses.

For a proper description, some transformations of serum lipid levels were thought to be necessary (model 1 in table 3 ). In addition, inclusion of a term representing multiplicative interaction between HDL and triglyceride was found to be helpful in increasing the fit of the model (model 2 in table 3 ). The result for total cholesterol from model 2 represents a multiplication of the odds of gallstones by $\mathrm{e}^{-0.346}=0.71 \mathrm{per} \mathrm{mmol} / \mathrm{L}$ increase in total cholesterol level (CL-95\% 0.61, 0.83). For instance, the relative risk of gallstones associated with a cholesterol level of $7 \mathrm{mmol} / \mathrm{L}$ relative to one of $6 \mathrm{mmol} / \mathrm{L}$ is 0.71 (CL$95 \% 0.61-0.83$ ); for a cholesterol level of $9 \mathrm{mmol} / \mathrm{L}$ relative to $6 \mathrm{mmol} / \mathrm{L}$ this is $0.71^{3}=$ 0.36 (CL-95\% 0.23, 0.57). The result from model 1 is similar. Figure 1 presents the odds ratios associated with HDL cholesterol and triglyceride, as derived from model 2 .

In order to confirm the shape of the simultaneous regression curves for $\mathrm{HDL}$ cholesterol and triglycerides as represented in the figure, multivariate logistic regression analysis was repeated with the serum lipids as categorical variables. This confirmed that the risk gradient for HDL cholesterol was steepest at low HDL levels and flat at higher levels. The dependence on HDL cholesterol levels of the positive association between triglyceride and the presence of gallstones was also confirmed, the odds gradient being smallest at low HDL levels. It should be noted that the dependence is mutual; therefore, the results may just as well be interpreted as a dependence on triglyceride of the relation between HDL and gallstones.

Separate multivariate logistic regression analyses for men and women indicated that model 2 was valid for both sexes.

TABLE 3 Results of multivariate logistic regression analysis of serum lipids and regression coefficients with standard errors ${ }^{\mathrm{A}}$

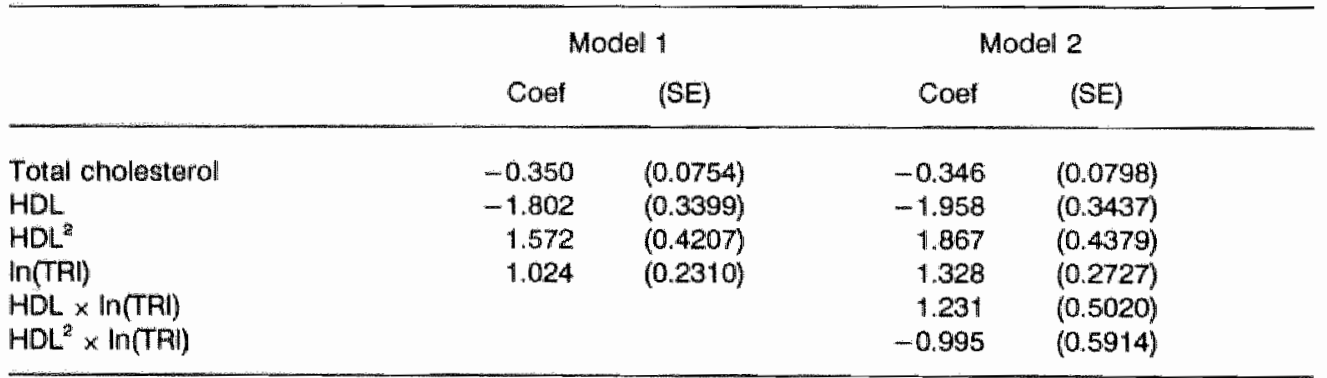

NOTE. Sorum lipids in mmol/L; further terms: included in the models were age and sex; $P$ value of gain in fit of modial 2 relative to inodel 1 equallad 0.037 .

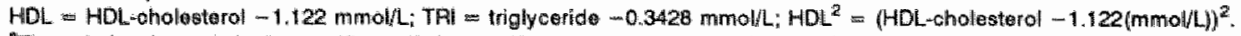

"The relation is statistically signitiont the coefficiont (Coef) exceedis its standard orrol (SE) times 1.96 (aipha $=0.025$ one sided or 0 os wo-sldod test). 


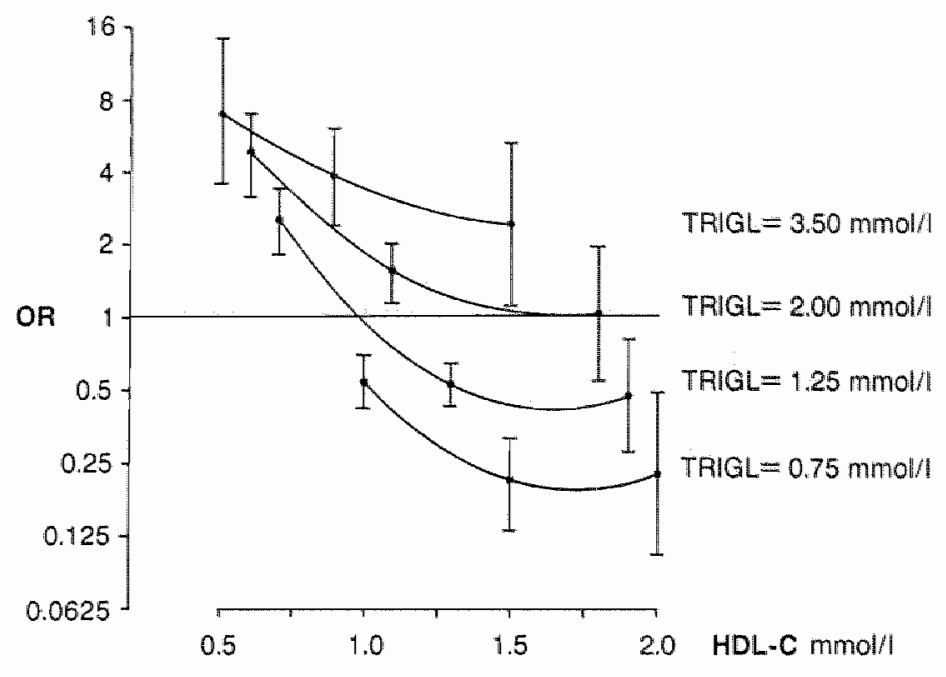

FIGURE 1 Relative risk of gallstones (estimated by the odds ratio, OR) as a function of serum lipid levels. Reference serum lipid levels for gallstone risk $(O R=1)$ have been chosen at the median levels of HDL-cholesterol $(1.0 \mathrm{mmol} / \mathrm{L})$ and triglycerides $(1.25 \mathrm{mmol} / \mathrm{L})$. Vertical bars indicate $95 \%$ confidence intervals.

The consistency of the results in the various groups of origin (radiology and surgery patients) was checked. This was done by separate studies of subjects who were comparable for the circumstances of blood sampling: case patients vs. control patients from the group of radiology patients ( 51 and 162 subjects, respectively, see table 1 ); cholecystectomy case patients vs. surgery control patients (172 and 364 subjects); and case patients found by screening among surgery patients vs. the same surgery controls ( 27 and 364 subjects). An inconsistency was only found for serum total cholesterol. The group of radiology patients showed no association (odds ratio for 9 vs. $6 \mathrm{mmol} / \mathrm{L}$ of serum total cholesterol: 1.05 (CL-95\% 0.44, 2.53)). By contrast, the association in cholecystectomy cases was substantial (odds ratio 0.24 (CL-95\% 0.13, 0.45), P-value for the contrast with the radiology group, 0.005). Surgery cases found by screening showed a less obvious association (odds ratio 0.56 (CL-95\% $0.19,1.65$ )).

In the next section, only model 1 is presented, because of the ready interpretability of its regression coefficients. Chemical analysis of gallstones was performed in 160 of the 172 gallstone case patients from the cholecystectomy group. Gallstone classification resulted in identifying 26 subjects with pigment stones ( 11 men and 15 women) and 122 subjects with cholesterol stones ( 34 men and 88 women), leaving out 12 unclassified ("mixed") stones. The percentage of cholesterol ranged from $0.3 \%$ to $19.1 \%$ (mean $5 \%$ ) in pigment stones and from $61.0 \%$ to $99.0 \%$ (mean $77 \%$ ) in cholesterol stones. 
Pigment gallstones showed the same pattern of serum lipid levels as cholesterol gallstones. None of the lipid levels in pigment stone cases showed a statistically significant difference with those in cholesterol gallstone cases (at alpha $=0.025$, one-sided). By contrast, HDL cholesterol and triglyceride levels in pigment gallstone cases differed substantially from the levels expected on the basis of the levels found in control subjects (table 4).

The results of the logistic regression analysis support the impression that pigment stones are associated with serum lipids to the same extent as cholesterol stones (table 5). The regression coefficients of serum lipids in pigment stone case patients vs. control patients were similar to those in cholesterol stone case patients vs. control patients. Both pigment and cholesterol gallstone cases had a contrast with controls that was statistically significant for the whole serum lipid pattern (at alpha $=0.025$; one-sided test). In summary, pigment and cholesterol gallstones are found to be associated with serum lipid levels to a similar extent.

TABLE 4 Relative mean difference (MD\%) of serum lipid levels in gallstone cases according to gallstone type, with their $95 \%$ confidence limits, standardized for age and sex

\begin{tabular}{|c|c|c|c|c|}
\hline & \multicolumn{4}{|c|}{ Gallstone type } \\
\hline & \multicolumn{2}{|c|}{ Pigment } & \multicolumn{2}{|c|}{ Cholesterol } \\
\hline & MD\% & $(C L-95 \%)$ & $M D \%$ & $(C L-95 \%)$ \\
\hline Total cholesterol MD\% (CL-95\%) & $-7 \%$ & $(-15,+1.9)$ & $-12 \%$ & $(-20,-3.0)$ \\
\hline HDL-cholesterol MO\% (CL-95\%) & $-21 \%$ & $(-34,-8.7)$ & $-19 \%$ & $(-32-6.8)$ \\
\hline Triglyceride MD\% (CL-95\%) & $+45 \%$ & $(+84+5.7)$ & $+15 \%$ & $(+45,-15)$ \\
\hline No. of cases & & 26 & & 122 \\
\hline
\end{tabular}

TABLE 5 Results of logistic regression analysis with model 1 (including age and sex) of subgroups of gallstone cases according to gallstone type, regression coefficients (Coef) with standard errors (SE)

\section{Gallstone type}

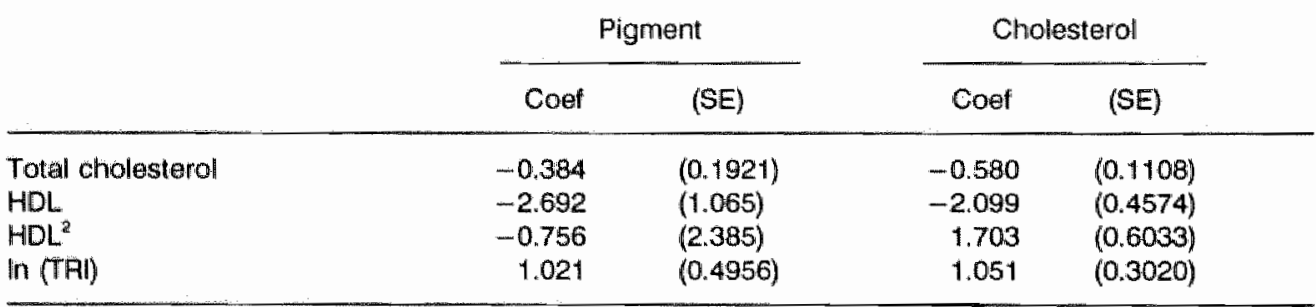

NOTE. Tramstormation of serum lipicl variables an in table 3 . 
As expected, body mass index (weight/height') was positively associated with gallstone risk in both men and women. Linear logistic regression analysis of body mass index, controlling for age and sex, yielded an odds ratio of 1.67 (CL-95\% 1.10, 2.52) per 10 $\mathrm{kg} / \mathrm{m}^{3}$ increase in body mass index. Inclusion of the serum lipid variables in the model made the association between body mass and gallstone risk disappear almost completely (odds ratio 1.11 per $10 \mathrm{~kg} / \mathrm{m}^{2}, \mathrm{CL}-95 \% 0.70,1.75$ ). Conversely, the association between serum lipids and gallstone risk hardly changed when body mass index was included in the model.

\section{DISCUSSION}

The present study confirms the results of earlier studies of serum HDL cholesterol and triglyceride levels in gallstone patients. Total serum cholesterol level was found to be slightly but significantly lower in gallstone patients. When the associations between each serum lipid level and gallstone risk were adjusted for both of the other serum lipids studied, each serum lipid was found to make a separate contribution.

In retrospect, two earlier large studies on serum lipids and gallstone risk also found a weak negative association between total serum cholesterol and gallstones, in both men and women in one study ${ }^{8}$ and in women only in the other. By contrast, the smaller studies did not find any significant associations, except for a positive association in one study $^{10}$. Unfortunately, the latter paper does not tell how the control group was selected. As an explanation of the observation that a negative association between serum cholesterol and gallstones was only found in the larger studies, we propose that the association is too weak to be detected in studies with few subjects. Nevertheless, the inconsistency of the association between total serum cholesterol and gallstones in the various groups of origin of our study remains unexplained.

Before discussing the results with respect to gallstone types and the role of body mass, the internal validity of our study deserves some attention.

\section{Time relation between serum lipids levels and gallstone disease}

In a case-control study of causal determinants of a disease, information about the determinants should relate to their levels at the presumed time of causation. However, in this study serum lipids were measured at a time when the disease was already present. Several interpretation problems might arise as a result. First, if current serum lipids in the study subjects are only weak indicators of the serum lipidl levels at the critical time of gallstone development, the strength of the causal effect may be underestimated. A second, more serious problem is that the presence of gallstones may have influenced serum lipid levels by the time these were measured. Any influence of cholecystectomy was avoided by sampling blood before operation. However, there is another potential mechanism by which the presence of gallstones could affect serum lipids. Previous studies have reported high serum cholesterol levels caused by the presence of an abnormal LDL class (LP-X) ${ }^{2 \times 31}$ in cases of intrahepatic or extrahepatic cholestasis, as well as low HDL levels with an abnormal HDL componen ${ }^{32}$. This suggests that changes in serum lipid metabolism is a possible consequence of the presence of gallstones, especially through biliary obstruction. However, because only few of our gallstone case 
patients had reported symptoms of biliary obstruction in the past (jaundice, pale stools or dark urine), we believe that only few of the gallstone case patients will have had cholestasis at the time of the study. Nevertheless, we cannot exclude more subtle changes in lipid metabolism as a consequence of the presence of gallstones. In this respect, it is notable that serum lipid levels in subjects with a history of cholecystectomy were found to be more similar to controls than to subjects with gallstones?

\section{Other possible biases}

Lipid analysis was performed blindly for the disease status of the subjects. Comparability of situational influences on serum lipids because of stress of hospital admission, the time of the day when blood was sampled, and the position of the patient during sampling was ensured by selecting hospital controls. Subjects chosen as controls had diseases assumed to be unrelated to serum lipid levels. However, a negative association between obesity and inguinal hernia has been reported ${ }^{33}$. This was confirmed in the present study when comparing body mass indexes of male inguinal hernia patients and other male control subjects (results not shown). As serum lipids are known to be associated with body mass index, the validity of the selection of inguinal hernja patients as controls can be questioned. However, two observations enable us to refute this selection bias. First, the associations between serum lipids and gallstones were also found in women, whereas only a minority of the female control patients were inguinal hernia patients. Second, when the association between serum lipids and gallstones was studied in multivariate analysis, controlling for body mass index, the association did not change. This precludes confounding by body mass index.

A study design less liable to selection bias is the screening of a population of subjects without known gallstone disease. It is also less likely in such a study that serum lipids in gallstone cases have changed as a consequence of dietary modification because of symptoms. The results of studies with such a design were similar to ours with regard to the association of gallstones with HDL cholesterol and triglyceride levels ${ }^{9}$ and hypertriglyceridemia ${ }^{19}$. However, this type of study does not allow a distinction between cholesterol and pigment gallstones.

\section{Serum lipids in pigment $\psi$ s. cholesterol gallstone disease}

It is generally agreed that bile cholesterol saturation is not involved in the pathogenesis of pigment gallstones ${ }^{3+1,35}$. On the other hand, Soloway et al., in a thorough review of the literature, concludes that there is strong evidence for a role of biliary lipids in the solubilization of unconjugated bilirubin, which in turn is thought to be involved in the development of pigment stones ${ }^{\text {t6 }}$. Remarkably, the associations between serum lipid levels and pigment stones in the present study were of the same pattern as the associations with cholesterol stones. This suggests that serum lipids play just as big a role in the pathogenesis of pigment stones as in that of cholesterol stones, possibly via a common pathway in their pathogenetic mechanisms. As a corollary, pigment and cholesterol gallstones may share more causal determinants than previously suggested, especially factors lowering HDL cholesterol and/or raising triglyceride levels in serum. However, the finding of a similar serum lipid pattern in pigment and cholesterol gallstone disease is also consistent with the hypothesis that the association with serum 
lipids is merely a consequence of an influence of the presence of gallstones on serum lipid levels. Because the present study and similar cross-sectional studies cannot distinguish between cause and effect, and because of the limited power of our study to detect subtle differences between pigment and cholesterol gallstones with respect to serum lipids, our results need to be confirmed by further, preferably longitudinal studies.

\section{Serum lipids, obesity and gallstones}

The relation between serum lipids and gallstone risk could not be explained by body mass. On the contrary, the relation between gallstone risk and body mass almost disappeared after adjustment for serum lipid levels. This indicates that both risk factors are linked to the same mechanism of gallstone development and, in addition, that serum lipids are more closely linked to the pathogenesis of gallstones than body mass. In contrast to our results, previous studies in which body mass index and serum lipids were studied by multivariate analysis did find a contribution of body mass index to gallstone risk additional to serum lipids ${ }^{9,15,16}$. We do not have an explanation for this discrepancy.

\section{REFERENCES}

1. Van der Linden W. Some biological traits in female gallstone-disease patients. Acta Chir Scand 1961:(Suppl 269):1-94.

2. Friedman GD, Kannel WB, Dawber TR. The epidemiology of gallbladder disease: observations in the Framingham study. J Chron Dis 1966;19:273-92.

3. Sampliner RE, Bennett PH, Comess $\mathrm{L}_{\mathrm{J}}$, et al. Gallbladder disease in Pima indians, demonstration of high prevalence and early onset by cholecystography. N Engl I Med 1970;283:1358-64.

4. Bell GD, Lewis B, Petrie A, et al. Serum lipids in cholelithiasis: effect of chenodeoxycholic acid therapy. Br Med J 1973;3:520-3.

5. Kadziolka $R$, Nilsson $S$, Scherstén $T$. Prevalence of hyperlipoproteinemia in men with gallstone disease. Scand J Gastroenterol 1977;12:353-5.

6. Stout RW, Balmer JP, Henry RW, et al. Plasma lipids and gastro-intestinal hormones in subjects with gallstones. Horm Metab Res 1978;10:357-8.

7. Ahlberg $\mathrm{J}$. Serum lipid levels and hyperlipoproteinemia in gallstone patientsi. Acta Chir Scand 1979; $145 * 373 \sim 7$.

8. Scragg RKR, Calvert GD, Oliver JR. Plasma lipids and insulin in gallstone disease: a case-control study. Br Med J 1984;289:521-5.

9. Rome group for epidemiology and prevention of cholelithiasis (GREPCO). The epideniology of gallstone disease in Rome, Italy. Part II. Factors associated with the disease. Hepatollogy 1988;8:907. 13.

10. Hassan TJ, Maqsood R, Zuberi SJ. Lipid pattern in cholelithiasis. J Pakistan Med Assoc 1979;29:93-6.

11. Sarles $H_{\text {, Crotte }}$, Gerolami A, et al. Influence of cholestyramine, bille sallt, and cholegterol feeding on the lipid composition of hepatic bile in man. Scand J Gastroemterol 1970;5:603-8.

12. Dam H, Prange 1 , Krogh Jensen $M$, et al. Studies on human bile IV. Influence of ingestion of cholesterol on the composition of bile in healthy subjects. Zeitschrift für Ernathrungswissenschaft 1971;10:178-87.

13. Den Besten $L$, Connor WE, Bell $S$. The effect of dietary cholesterol on the composition of human bile. Surgery 1973;73:266-73.

14. Andersén $\mathbb{E}$, Hellstrom $K$. The effect of chollesterol feeding on bile acid kinetics and billary lipids in normolipidemic and hypertriglyceridemic subjects. I Lipid Res 1979;20:1020-7. 
15. Scragg RKR, Mchichael Al, Baghurst PA Diet, alcohol and retative weight in gallstone disease: a caste-Gontrol study. Br Med J 1984,288:1113-9.

16. Petitu DB, Fricdman GD, Kilatsky AL. Association of a history of gallbladder disease with a reduced concentration of high-density-lipoprotein cholesterol. N Engl J Med 1981;304:1396-8.

17. Thomton JR, Heator KW, MacFarhane DG. A relation between high-density-lipoprotein cholesterol and bile cholesterol saturation. Br Med J $1981,283: 1352-4$.

18. Thornton $d$, symes $C$, Heaton $K$. Moderate alcohol intake reduces bile cholesterol saturation and raises HDL cholesterol. Lance 1983, $11 ; 8192,22$.

19. Barbara $L$, Sama $C$, Morselli Labate AM, et al A population survey on the prevalence of gallstone disease: the Sirmione study. Hepatology 1987;7:913-7.

20. Van der Linden W, Bergman F. An analysis of data on human hepalic bile. Relationship between main bile components, serum cholesterol and serum triglycerides. Scand J Clin Invest 1977;37:741-7.

21. Einarsson $K_{*}$ Hellstrom $K$, Kallner $M$. Gallbladder disease in hyperlipoproteinaemia. Lancet $1975 ; \mathrm{i}: 4847$,

22. Ahlberg J. Angelin B, Einarsson $K_{\text {y }}$ er al. Prevalence of gallbladder disease in hyperlipoproteinemia. Dig Dis Sci 1979;24:459-64.

23. Lopes-Virella MF, Stone P, Ellis $S$, et al. Cholesterol determination in high-density lipoproteins separated by three different methods. Clin Chem 1977;23:882-4.

24. Miettinen OS. Theoretical Epidemiology. New York: Wiley, 1985: p, 204 and 272.

25. Kleinbaum DG, Kupper LL. Applied regression analysis and other multivariate methods. North Scituate: Duxoury Press, 1978.

26. Belsley DA, Kuh E, \& Welsch E. Regression diagnostics. New York: Wiley 1980.

27. Trotman BW, Ostrow JD, Soloway RD. Pigment vs. cholesterol cholelithiasis: comparison of stone and bille composition. Am J Dig Dis 1974;19:585-90.

28. Trotman BW, Morri TA, Sanchez HM, et al. Pigment vs. cholesterol cholelithiasis: identification and quantification by infrared spectroscopy. Gastroenterol 1977;72:495-8.

29. Switzer S, Satenstein L. Plasma lipoproteins in liver disease: I. Immunologically distinct low-density lipoproteins in patients with biliary obstruction. J Clin Invest 1967;46:1855-66.

30. Seidel $D$, Alaupovic P, Furman RH. A lipoprotein characterizing obstructive jaundice. I. Method for quantitative separation and identification of lipoproteins injaundiced subjects. J Clin Invest $1969 ; 48: 1211-23$.

31. Picard $\mathrm{J}$, Veissiere D. Abnormal serum lipoprotein in cholestasis: identification and isolation. Clim Chim Acta 1970;30:149-55.

32. Danielsson $B$, Ekman $\mathbb{R}$, Petersson $B G$. An abnormal high densily lipoprotein in cholestatic plasma isolated by zonal ultracentrifugation. FEBS Lett 1975;50:180-4.

33. Abramson JH, Gofin J, Hopp $\mathrm{C}$, et al. The epidemiology of inguinal hernia. A survey in western Jerusalcm. J. Epidemiol Commun Health 1978,32:59-67.

34. Bennion L. Orundy SM. Risk factors for the development of cholelithiasis in man (second of two parts). N Eng J Med 1978;299:1221-7.

35. Soloway RD, Malet PF. Classification and pathogenesis of pigment gallstomes In: Capocaccia $\mathrm{L}$ ed. Epidcmiology and prevention of gallsione disease. Lancaster: MTP Press 1984; 58.

36. Soloway RD, Troiman BW, Ostrow JD. Pigment gallstones. Gastroenterology 1977;72:167 82 . 
ALCOHOL

\section{Beschermt alcoholgebruik tegen de vorming van galstenen? - een demonstratie van protopathische vertekening}

Eerder onderzoek heeft een omgekeerde relatie aangetoond tussen alcoholgebruik en de kans op klinische galsteenziekte. Dit suggereert een beschermend effect van alcoholgebruik. Men kan tegenwerpen dat een dergelijke relatie wordt teweeggebracht door vermindering van alcoholgebruik onder invloed van klachten die verband houden met galsteenziekte (protopathische vertekening). In een serie patiënt-controle onderzoeken evalueerden wij empirisch de consequenties van verschillende onderzoeksopzetten op de mate waarin deze vertekening vermeden kan worden.

Een eerste onderzoek (studie A) was bewust ontworpen zoals vaak in de epidemiologische literatuur wordt gezien. Tegenover patiënten met klinische galsteenziekte die naar het ziekenhuis waren verwezen wegens klachten, werd een controlegroep gezet van personen uit de algemene bevolking. Een omgekeerde relatie tussen alcoholgebruik en galsteenziekte werd gevonden. De gevonden mate van het beschermend effect is goed vergelijkbaar met dat beschreven in eerder onderzoek: relatieve risico's voor wekelijks drinken waren 0,8 bij minder dan éen glas/dag, 0,7 bij $1-2$ glazen/dag, en 0,6 bij 3-7 glazen/dag (ten opzichte wan niet-drinken).

Hiertegenover werden drie patiënt-controle onderzoeken gezet met onderzoeksopzetten die protopathische vertekening zouden moeten kuinnen tegengaan: patienten met alleen acute galsteenziekte vs. algemene bevolking (studie B1); personen met vs. zonder galstenen bij echografische screening (studie B2); en patiënten met vs. zonder galstenen in een groep patiënten die met vergelijkbare klachten waren verwezen voor een radiodiagnostisch onderzoek van de galblaas (studie B3). In geen van deze drie onderzoeken werd een relatie tussen alcoholgebruik en galsteenziekte aangetoond.

Dit demonstreert het bestaan van protopathische vertekening in onderzoek op dit gebied. Deze vertekening heeft mogelijk geleid tot een overschatting van het beschermend effect van alcohol in eerder onderzoek. 


\title{
DOES ALCOHOL PROTECT AGAINST THE FORMATION OF GALLSTONES? A DEMONSTRATION OF PROTOPATHIC BIAS
}

\author{
Carel Thijs, Paul Knipschild and Pieter Leffers \\ Department of Epidemiology/ Health Care Research, Rijksuniversiteit Limburg, \\ The Netherlands
}

\begin{abstract}
Previous studies have found an inverse relation between alcohol use and clinical gallstone disease, suggestive of a protective effect of alcohol use. However, such an inverse relation may (at least partly) be explained by a reduction of alcohol use because of symptoms related to clinical gallstone disease (protopathic bias). We empirically evaluated the consequences of different designs for the avoidance of such bias in a series of casecontrol studies. A first study deliberately used a design that is commonly seen in the literature. Cases of clinical gallstone disease, referred to hospital because of symptoms, were contrasted with general population controls. The results suggested an inverse relation between alcohol use and gallstones. Nexi, three altemative case-control siudies were performed using designs that safeguard against protopathic bias. In none of these studies was an assaciation between alcohol use and gallstones found. This demonstrates the probable existence of protopathic bias in case-control studies on alcohol use and gallstones. It is argued that eartier non-experimental studies on this topic were susceptible to such bias. This has most likely led to an overestimation of the protective effect. (J Clin Epidemiol 1991;44:941-6)
\end{abstract}

\section{INTRODUCTION}

The results of two experimental studies have supported the idea of a protective effect of alcohol use against the formation of gallstones. In the prairy dog, alcohol supplementation prevented the formation of gallstones by decreasing bile lithogenicity! In a human experiment moderate alcohol use was shown to decrease bile lithogenicity? Therefore, a protective effect of alcohol against gallstone disease would appear to be plausible.

Studies in man directly relating alcohol use to gallstone disease have all been nonexperimental. Three case-control studies ${ }^{* 5}$ and three cohort studies ${ }^{6.8}$ have shown an inverse relation between moderate alcohol use and the risk of gallstone disease, confirming a protective effect of alcohol use. These studies comprised cases referred to hospital because of clinical gallstone disease. Many of these cases will have suffered from 
gastrointestinal symptoms that may have caused them to reduce their alcohol use. This may have led to the finding of a spurious inverse relation between alcohol use and clinical gallstone disease (or an overestimation of an existing protective effect). This bias has been described as protopathic bias".

Such a bias may even be due to symptoms that are not caused by gallstones, but that are common among clinical gallstone cases because of patient selection. Long-standing, more or less vague "dyspeptic" symptoms may lead to referral to hospital for a diagnostic examination of the gallbladder, with subsequent diagnosis of gallstones and elective surgical operation. Thus protopathic bias may (at least partly) be a matter of selection processes introduced into the study by the choice of clinical gallstone patients as the case series. We will refer to this as "selection-based protopathic bias".

This paper empirically illustrates this bias. For that purpose we present a case-control study of clinical gallstone disease without specific measures to prevent protopathic bias (study A). Next we present three alternative case-control studies with various designs safeguarding against such bias (studies B1, B2 and B3).

\section{METHODS}

\section{Study A. Clinical gallstone study}

Gallstone cases were recruited from a consecutive series of patients in whom gallstones were newly diagnosed in Academic Hospital Maastricht between mid 1983 and mid 1985. These patients were identified at the rosters of admissions to the surgical and internal wards, and a registry of patients in whom gallstones were diagnosed at the Department of Radiodiagnosis; 207 gallstone cases agreed to participate (response rate $86 \%$ ).

As the control group, a random sample from the general population of the catchment area of the hospital (the only hospital in the region) was chosen. The sample was composed of age- and sex-stratified random samples from municipal population registries of the town of Maastricht and its surroundings. The response rate was $72 \%$. Subjects were excluded from the control group if they reported previous cholecystectomy, history of radiological gallstone diagnosis, or medical diagnosis of billary colics. After exclusions, 451 subjects were available in the control group.

\section{Studies $B$. Three alternative case-control studies avoiding protopathic bias}

B1 Acute gallstone study. This study aimed to avoid selection-based protopathic bias by means of restriction of the case series to gallstone patients with recent symptoms that always led to hospital referral (acute gallstone disease). Apart from such symptoms, these cases may also have had symptoms which are not causally related to gallstone disease, but these symptoms were expected to be as prevalent as in the general population. Therefore, no selection based protopathic bias was expected to be present when using controls from the general population.

Protopathic bias due to acute symptoms was avoided by using only data about alcohol use before the onset of such symptoms.

Cases were 151 patients with an acute indication for hospital admission among the patients from the cases series described in study A. Criteria for such an acute indication 
were a diagnosis of biliary colic, acute cholecystitis, cholangitis, pancreatitis, or biliary obstruction, as reported in the hospital records. The same control group as in study $\mathrm{A}$ wass used.

B2 Screening study. In a second study selection based protopathic bias was avoided by studying a general hospital population, ascertaining cases by screening. Candidates were patients aged 20 to $80_{4}$ who were admitted to the Academic Hospital Maastricht for certain surgical procedures of elective character, not known to be related to gallstone disease or gastrointestinal symptoms, and who had no previous radiologically or surgically confirmed diagnosis of gallstones. 902 Subjects were willing to undergo ultrasound screening of the gallbladder. The ultrasound screening was done by radiologists at the Department of Radiodiagnosis. The exam was inconclusive in 10 subjects. No gallstones were found in the group of patients under 30 years of age $(n=40)$. The analysis was restricted to the remaining 852 subjects. Of the 357 men most $(56 \%)$ were operated for inguinal hernia. Most of the 495 women were operated for gynaecological problems (22\%), carpal tunnel syndrome (27\%), or varicose veins (25\%). Gynaecological diagnoses were mainly combinations of prolapsus of the uterus/vagina, myoma of the uterus and cysto/rectocele. The other patients were operated for cataract, femoral hernia, haemorrhoids, osteoarthrosis of the hip, hallux valgus (deviation of the big toe), and removal of osteosynthesis material after treatment for fracture.

B3 Radiodiagnosis study. Selection-based protopathic bias was avoided by choosing controls who had undergone a selection procedure as similar to that of the gallstone cases. This was done by recruiting both cases and controls from a series of patients referred for a diagnostic examination targeted at gallstone disease. Candidates were patients age 20 to 80 who were referred to the Department of Radiodiagnosis of the Academic Hospital Maastricht for an ultrasound or X-ray exam of the gallbladder or upper abdomen. These subjects were included if the referral form stated that the radiodiagnostic exam was targeted at gallstones, and if gallstones had not been previously diagnosed. The radiodiagnostic exam was inconclusive in 7 of the 436 participants, leaving 429 patients for analysis. The case series of this study $(n=77)$ overlapped that of the acute gallstone study by 21 cases, and that of the clinical gallstone study by 44 cases.

\section{Measuremens}

Interviews were done by research assistants from our department, by the first author, and by interviewers from an external bureau. Questionnaires addressed putative risk factors for gallstone disease and history of gastrointestinal symptoms (colic, right upper abdominal pain, pain in the gastric region, gastric bloating, pyrosis, nausea, and belching). Participants were also asked whether they had changed their alcohol use because of any gastrointestinal symptoms. Information about alcohol use in the past $(5$, 10 and 15 years before interview) was only available in the acute gallstone study. In the other studies the questions referred to "habitual" alcohol use.

\section{Analysis}

Moderate regular alcohol use was defined as weekly drinking, and divided into categories according to alcohol use: $<1$ drink/day (1-6 drinks/week), 1-2 drinks/day (6-17 drinks/week), and 3-7 drinks/day (17-50 drinks/week). Non-drinking (regular drinking, but 
less than once a week and alcohol use less than one drink per week) was taken as the reference category. A category "other" included occasional drinkers, regular heavy drinkers (more than 7 drinks/day), and missing values.

As explained above, only data on alcohol use before the onset of acute symptoms was used in the acute gallstone study (Study B1). We focused on alcohol use 10 years before interview. The choice of this intervall was based on the reported mean latency period between the formation of gallstones and hospitalization for gallstone disease ${ }^{10}$. None of the women under age 25 were weekly drinkers as early as 10 years before interview. Therefore the analysis was restricted to women of age 25 or over, excluding the women below this age ( 5 cases and 5 controls).

Relative risks were estimated by means of odds ratios, computed by categorical logistic regression analysis" ${ }^{\text {. }}$

\section{RESULTS}

In the clinical gallstone study (study A), an inverse dose-effect relation between alcohol use and risk of gallstone disease was found, consistent with a protective effect (table 1). Reduction of alcohol use because of gastrointestinal symptoms was reported by $14 \%$ $(28 / 207)$ of the cases and $2 \%(11 / 451)$ of the population controls.

In the three alternative case-control studies (studies B1-B3) the odds ratios varied somewhat across the categories of alcohol use, but in none of the studies a consistent inverse dose-effect relationship was observed (table 2). Except for biliary colic, the prevalence of gastrointestinal symptoms was similar for cases and controls in all three studies. More importantly, changes in alcohol use because of symptoms was also as frequent in cases as in controls. In the acute gallstone study (B1) none of the cases had

TABLE 1 Clinical gallstone study (study A); cases and controls by habitual alcohol use; odds ratios (OR) with $95 \%$ confidence intervals $(95 \% \mathrm{Cl}){ }^{*}$

\begin{tabular}{|c|c|c|c|c|c|c|}
\hline \multirow[b]{3}{*}{ Non-drinking } & \multicolumn{2}{|c|}{ Men } & \multicolumn{2}{|c|}{ Women } & \multirow{2}{*}{\multicolumn{2}{|c|}{ OAt (Cl-95\%) }} \\
\hline & \multicolumn{2}{|c|}{ cases controls } & \multicolumn{2}{|c|}{ cases controls } & & \\
\hline & 16 & 26 & 73 & 141 & 1.0 & (reference) \\
\hline Weekly drinking & & & & & & \\
\hline$<1$ drink/day & 9 & 22 & 18 & 48 & 0.8 & $(0.44-1.47)$ \\
\hline 1.2 drinks/day & 23 & 47 & 24 & 68 & 0.7 & $(0.41-1.18)$ \\
\hline 3-7 drinks/day & 11 & 31 & 7 & 27 & 0.6 & $(0.34-4.35)$ \\
\hline Other & 7 & 20 & 19 & 21 & & \\
\hline Total & 66 & $\$ 46$ & 141 & 305 & & \\
\hline
\end{tabular}

* Variables comtroltad for: age (6 aategaries); siex (2); coffeo wse (5); smoking (4); progranciles (included as an interval

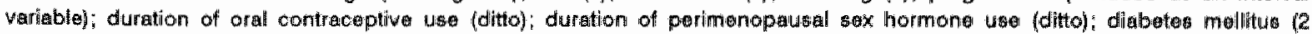
categories): body mass index (weight divided by height squared; 5 categories).

+ Test for trend (from logistic regression analysis whth alcahol use as a log-transformad interval wariable) onionsidad pen 0.00 
changed alcohol use because of symptoms more than 10 years before interview, whereas a reduction was reported by 5 population controls (1\%). In the screening study (B2) a reduction symptoms was reported by 2 cases (3\%) and 29 controls (4\%), and in the radiodiagnosis study (B3) by 12 cases (16\%) and 50 controls (14\%).

TABLE 2 Gallstone cases and controls by alcohol use 10 years before interview in the acute gallstone study (study B1), and by habitual alcohol use in the screening study (study B2) and the radiodiagnosis study (study B3); odds ratios (OA) with $95 \%$-confidence intervals (95\% Ci)

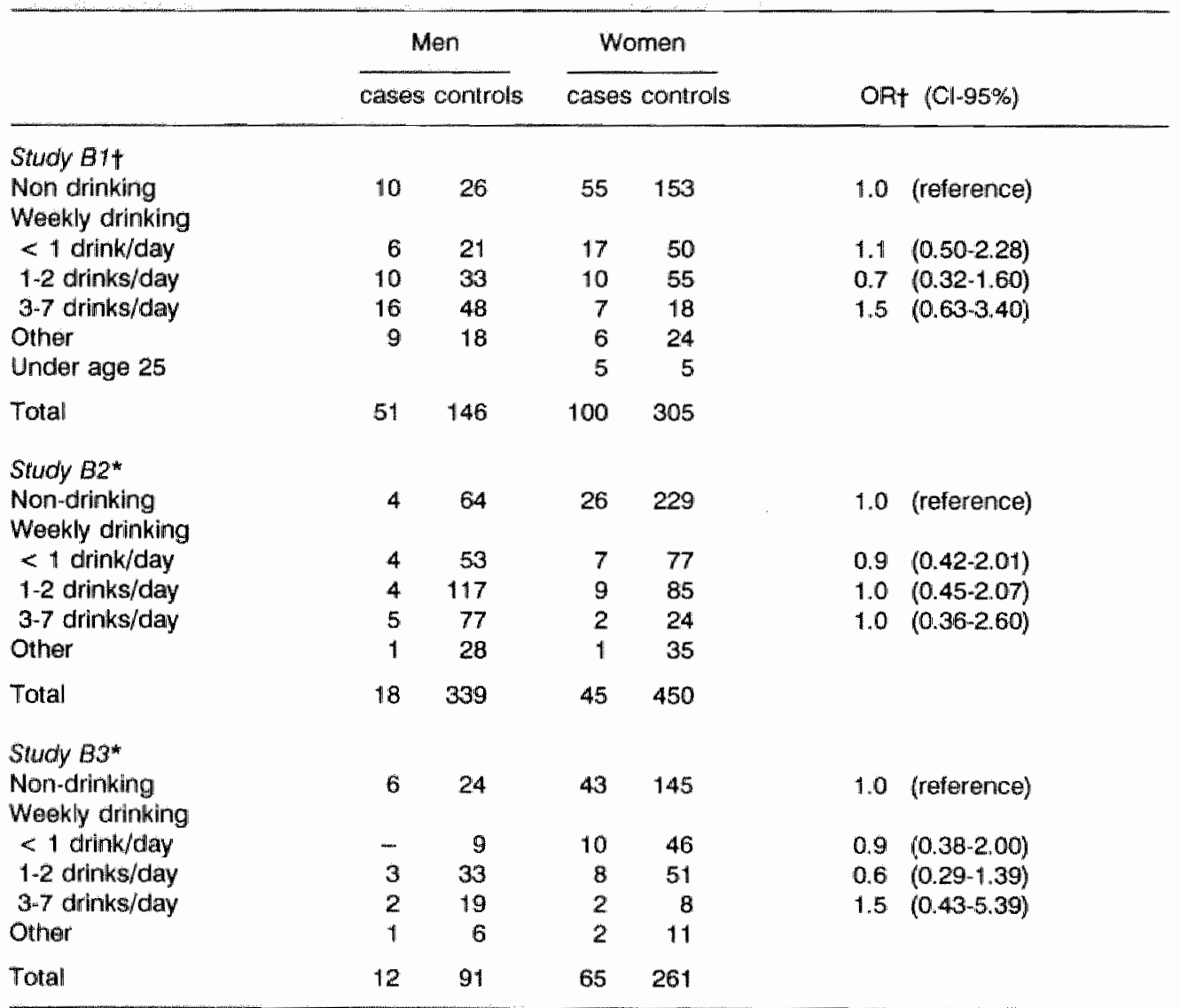

* Variabias contrallad for age (6e categories); sex (2) " coffeo us (5); smoking (4); prognancies (number); duration of aral coritraceptive use (number of yetar); duration of perimenopassal sex hormone use (nuber of years); diabetes mellitus (2 categorles); body mass index (woight divided by height squared; 5 categories).

+ Variables oontrolled for, additionally to those tisted under *: skipping breakflast (10 years betore intervew: 4 categories); sedentary iffe style (ditto; 2 categonies); sporting activities (in the period from 5 to 10 yoars before interview; 3 categories); slimming courses (ditto; 4 ategaries); age at monarche; number of yours postmenopausal; cholesteroflawering drug use (ever; 3 calegories): long-term dally analgesic use (ditto)i parents (3 calegories); brothers (ditto); sistep (ditto) with gallstones; interviewer (3 categories). 


\section{DISCUSSION}

Our clinical gallstone study showed an inverse dose-effect relation between habitual alcohol use and the incidence of gallstone disease. This relation was of the same magnitude as that found in earlier studies on clinical gallstone disease ${ }^{3-4} .14 \%$ of the clinical gallstone cases in our study reported reduced alcohol use because of gastrointestinal symptoms, whereas this was rarely reported by the general population controls. The resulting protopathic bias was avoided in the three alternative case-control studies. The designs succeeded in making cases and controls comparable with respect to selection on gastrointestinal symptoms, which should safeguard against selection-based protopathic bias. These studies showed no association between alcohol use and gallstones. Each of these studies had a low power to detect a moderate protective effect of the magnitude found in the positive studies. However, the consistency of the failure to show such an effect in all three studies renders it less likely that this failure is solely due to chance.

One of the earlier "positive" studies ${ }^{3}$ was a case-control study. Although this study is often cited as confirming the initial surmise of a protective effect of alcohol use, it showed a discrepancy in the results, depending on which of two control groups was considered. Cases were patients in whom gallstones were found at a radiodiagnostic exam, mainly for gastrointestinal symptoms. An inverse relation was found if the cases were contrasted to general population controls. If, on the other hand, the cases were contrasted to patients presenting for radiodiagnosis of the gallbladder in whom no gallstones were found, no relation could be shown. This discrepancy is very similar to the difference between our clinical gallstone study and our radiodiagnosis study, which strengthens the idea that the observed effect is at least partly due to protopathic bias.

Five earlier publications have reported on screening studies, in which alcohol use at the time of screening was related to the presence of gallstones found at ultrasound screening ${ }^{12-16}$. No relation was found in two of them ${ }^{12-14}$. One of these was a study among civil servants, of whom 204 were found to have gallstones or had undergone cholecystectomy. Habitual alcohol intake at the time of the study was assessed by means of a questionnaire, using a quantitative score ${ }^{13}$. The other was a study among women from a population screened for gallstones, with 121 gallstone cases and as many age-matched controls. Information about alcohol use was available from a four day fixed format dietary diary". The power of these "negative" studies is hard to assess, since the only information presented was that the association was not statistically significant.

Two other screening studies that also addressed alcohol use at the time of the study suggested a protective effect $t^{12-15}$. However, in these two studies many gallstone cases were already aware of having gallstone disease ${ }^{17.18}$ (as many as $40 \%$ in one study ${ }^{17}$ ), and these cases were reported to have abstained from alcohol more often than cases who were not aware of having gallstones ${ }^{13}$. In the last of the five screening studies a negative association was only found in women ${ }^{16}$. Interestingly, the association found in that study was of the same magnitude for cholecystectomy and gallstones present at screening, but unfortunately no information was provided on the presence of symptoms in the women with gallstones present at screening. 
It might be questioned whether protopathic bias could also have affected the results of the three large cohort studies of clinical gallstone disease ${ }^{6.5}$. First, subjects in these studies were not screened for gallstone disease, nor for gastro-intestinal symptoms at the outset. Some subjects who were later hospitalized for gallstone disease may in fact have had symptomatic, but as yet undetected gallstones at the time the questions on alcohol use were answered, and may already have reduced their alcohol use because of these symptoms. This may have led to (genuine) protopathic bias. Second, subjects in the cohort studies were not screened for gallstones at follow-up either. Gastrointestinal symptoms are quite prevalent in the general population, and may lead to lower alcohol use. Even if not caused by gallstones, such symptoms may have led to the detection of gallstones which would otherwise have remained undiagnosed. Therefore, selection-based protopathic bias may have occurred in the cohort studies as well.

Both genuine and selection-based protopathic bias will occur to a lesser extent in cohort studies than in case-control studies, because more gallstone cases in cohort studies will have got their symptoms only after the assessment of alcohol use. Nevertheless, protopathic bias may also occur in cohort studies.

To conclude, we have tried to demonstrate protopathic bias in a series of case-control studies on the protective effect of alcohol use against gallstone disease. We have argued that most earlier non-experimental studies on this topic were susceptible to such bias. This has most likely led to an overestimation of the protective effect.

\section{REFERENCES}

1. Schwesinger WH, Kurtin WE, Johnson $\mathbb{R}$. Alcohol protects against cholesterol gallstone formation. Ann Surg 1988; 207: 641-7.

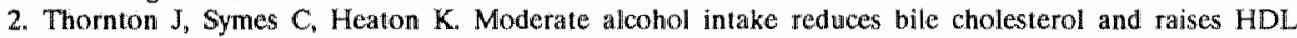
cholesterol. Lancet $1983 ; \mathrm{ii} ; 819.22$.

3. Scragg RKR, McMichael AJ, Baghurst PA. Diet, alcohol, and relative weight in gallstone disease: a case-control study. Br Med J 1984; 288: 1113-9.

4. Dichl AK, Haffier SM, Hazuda HP, Stern MP. Coronary risk factors and clinical gallbladder disease: an approach to the prevention of gallstones? Am J Publ Health 1987; 77: 841-845.

5. La Vechia $C$, Negri $E$, D'Avanzo B, Boyle $P$. The risk of gallstones in middle aged women. N Engl $J$ Med 1990; 322: 473, (Letter to the editor).

6. Friedman $G D_{\text {n }}$ Kannel WB, Dawber TR. The epidemiology of gallbladder disease: observations in the Framinghan study. J Chron Dis 1966; 19: 273-92.

7. Klatsky $A L$, Fricdman $G D$, Siegelaub $A B$. Alcohol use and cardiowascular disease: the KaiserPermanente experience. Circulation 1981; 64 (suppl 13): 116-36.

8. Maclure $\mathrm{KM}_{3}$ Hayes $\mathrm{KC}$ Coldiz $\mathrm{GA}$. Stampler MJ, Speizer FE, Willett WC Weight, diet, and the risk of symptomatic gallstones in middle-aged women. N Engl J Med 1989; 321: 563-9.

9. Feinstein AR. Clinical epidemiology. The architecture of clinical research. Philadelphia: Saunders, 1985.

10. Mok HY, Druffel ER, Rampone WM. Chronology of cholelithiasis, dating gallstones from aimospheric radiocarbon produced by nuclear bomb explosions. N Engl J Med 1986; 314: 1075-7.

11. Miettinen OS. Theoretical Epideniology. The principles of occurnence research. New York: Wiley, 1985.

12. Sama $C$, Morselli Labate AM, Comix GL, Rusticali AG, Taroni $F$, Roda $\mathbb{E}$, Barbara L Diet and galtstones - study on the general population. Dig Dis Sci 1986; 31 (suppl): 433 . 
13. Rome Group for Epidemiology and Prevention of cholelithitsis (GREPCO). The epidemiology of galstone disease in Rome, Italy. Part II. Factors associated with the disedse. Hepatoloy 1988; 8: 907. 13.

14. Pixley $F$, Mann J. Dietary factors in the setiology of gall stones: a case control study. Gut 1988; 29 : 1511-5.

15. Jorgenson T, Jorgenson LM. Gallstones and diet in a Danish population. Scand J Gastroeterol 1989; 24: 821-6.

16. Maurer KR, Everhart JE, Knowler WC, Shawker TH, Roth HP. Risk factors for gallstone discase in the Hispanic populations of the United States. Am J Epidemiol 1990; 131: 83644.

17. Barbara L, Sama C, Morselli Labate AM, Taroni F, Rusicicali AG, Festi D, Sapio C, Roda E, Banerle $C_{4}$ Puci A, et al. A population sudy on the prevalence of gallstone disease: the Sirmione Study. Hepatology 1987; 7: 913-7.

18. Jorgenson T. Prevalence of gallstones in a Danish population. Am J Epidemiol 1987; 126: $912-21$. 


\section{4 \\ ZWANGERSCHAP}

Zwangerschap en het risico op galsteenziekte:

een empirische demonstratie van het belang van

specificatie van risicoperiodes

In dit onderzoek wordt het belang van specificatie van risicoperiodes in etiologisch onderzoek gedemonstreerd aan de hand van een onderzoek naar de relatie tussen zwangerschap en galsteenziekte. Het betrof een patiënt-controle onderzoek bij vrouwen. Het omvatte 100 patiënten met acute galsteenziekte en 305 controlepersonen uit de algemene bevolking, en 41 patiënten en 122 controles die electief verwezen waren voor een radiodiagnostisch onderzoek van de galblaas wegens buikklachten.

In een conventionele analyse (zonder specificatie van risicoperiodes) werd een "rejatief risico" gevonden van 1,2 (90\% betrouwbaarheidsinterval 1,02-1-36) voor zwangerschap ooit (ten opzichte van nooit). In een analyse waarin de effecten in verschillende opeenvolgende risicoperiodes van elkaar werden gescheiden; werd alleen een effect gevonden in de eerste vijf jaar na zwangerschap (incidentiedichtheidsratio 2,4 (1.12-4.96)). In de daaropvolgende volgende risicoperiodes (6-10 jaar, 11-20 jaar, en 21 of meer jaar) werden geen effecten gezien.

De resultaten suggereren dat zwangerschap het optreden van galsteenziekte slechts tijdelijk verhoogt. Zes redenen om risicoperiodes te specificeren in etiologisch onderzoek worden besproken. 


\title{
4 \\ PREGNANCY AND GALLSTONE DISEASE - AN EMPIRIC DEMONSTRATION OF THE IMPORTANCE OF SPECIFICATION OF RISK PERIODS
}

\author{
Carel Thijs, Paul Knipschild and Pieter Leffers \\ Department of Epidemiology and Biostatistics, \\ Rijksuniversiteit Limburg, The Netherlands
}

\begin{abstract}
This paper discusses the importance of specification of risk periods in research of the effect of pregnancy on the occurrence of gallstone disease. The authors present data from a case-control siudy, started in 1983 in Maastricht, the Netherlands. The study comprised 100 acute gallstone cases and 305 general population controls; and 41 elective cases and 122 elective radiodiagnosis controls. In a conventional anabysis the rate ratio for one or more pregnancies ever (ws. never) was 1.2 (90\% confidence interval 1.021.36). In an analysis which discerned several subsequent risk periods, an effect was found only for the risk period up to five years after pregnancy (rate ratio, 2.4; $90 \%$ confidence interval 1.12-4.96). Beyond this risk period no effect was noted. The results suggest that pregnancy increases the rate of gallstone formation only transiently. Six reasons for specifying risk periods in nonexperimental etiological studies are discussed. The authors contend that ignoring of risk periods explains part of the variation in the findings of earlier studies on pregnancy and the risk of gallstone disease. (Am J Epidemiol 1991;134:186-95)
\end{abstract}

\section{INTRODUCTION}

Often, nonexperimental studies on the etiology of disease yield inconsistent results. Even in the case of the well-accepted relation between pregnancy and gallstone disease $e^{2}$ the variation in the results of studies is substantial (table 1). Rather than adding further dissenting results, any subsequent study should attempt to explain the inconsistency.

In our view, one of the causes of inconsistency in nonexperimental etiologic research is the ignoring of risk periods. This paper seeks to explore the relevance of specification of risk periods in the study of pregnancy and gallstone disease.

To set the scene, let us consider a hypothetical experiment about the effect of pregnancy on the occurrence of gallstone disease. Ideally, we would compare the incidence of gallstone disease in a group of women who were made pregnant with that in 
TABLE 1 Review of Controlled Studies of the Effect of Pregnancy/ Parity on the Risk of Gallstone/ Gallbladder Disease*

\begin{tabular}{|c|c|c|c|c|}
\hline \multirow{3}{*}{$\begin{array}{l}\text { Odds ratio } \\
\text { or } \\
\text { rate ratiot }\end{array}$} & \multicolumn{4}{|c|}{ Statistically significant positive association } \\
\hline & \multicolumn{2}{|r|}{ Yes } & \multicolumn{2}{|r|}{ No } \\
\hline & Yeat & Author (reference) & Year & Author (reference) \\
\hline Not reported & $\begin{array}{l}1067 \\
1973\end{array}$ & $\begin{array}{l}\text { Lomess (3) } \\
\text { Alichardson (5) }\end{array}$ & $\begin{array}{l}1956 \\
1970 \\
1970 \\
1975 \\
1977 \\
1980 \\
1980 \\
1985 \\
1987 \\
1989\end{array}$ & 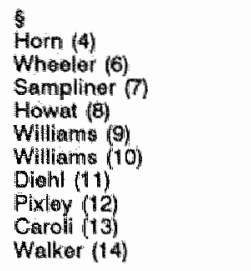 \\
\hline $0.5-0.9$ & & & 1987 & Maringhini (15) \\
\hline $1.0-1.5$ & $\begin{array}{l}1966 \\
1984 \\
1985 \\
1986 \\
1987 \\
1990 \\
1990\end{array}$ & $\begin{array}{l}\text { Friodman } 116) \\
\text { Boss }(18) \\
\text { Diehl (20)1 } \\
\text { Strom (22) } \\
\text { Barbark (24) } \\
\text { Sichieri (26) } \\
\text { Kritz-Silverstein(27) }\end{array}$ & $\begin{array}{l}1949 \\
1984 \\
1986 \\
1929 \\
1990\end{array}$ & $\begin{array}{l}\text { Erummer (17) } \\
\text { Serigg (19) } \\
\text { Wysowsiki (21) } \\
\text { Machume (23) } \\
\text { Maurer (25) }\end{array}$ \\
\hline $1.6-2.5$ & $\begin{array}{l}196 \\
1971 \\
1982 \\
1984 \\
1988\end{array}$ & $\begin{array}{l}\text { Van der Linden(28) } \\
\text { Bumett (30) } \\
\text { Layde (31) } \\
\text { Scragg (19y } \\
\text { Jorgensem (32) }\end{array}$ & 1970 & Peterson (29) \\
\hline $2.5-10$ & $\begin{array}{l}1931 \\
1973 \\
1979 \\
1982 \\
1984 \\
1986 \\
1987 \\
1988\end{array}$ & $\begin{array}{l}\text { Blümel (33) } \\
\text { Bernstein (34) } \\
\text { Ahlberg }(35) \\
\text { Sastic (35) } \\
\text { Knowlar (37) } \\
\text { Krislo (38) } \\
\text { Lee (39) } \\
\text { GREPCO (40) }\end{array}$ & & \\
\hline $10-50$ & $\begin{array}{l}1971 \\
1980 \\
1989\end{array}$ & $\begin{array}{l}\text { Thistle (4.1) } \\
\text { Honore }(42) \\
\text { Khuro }(43)\end{array}$ & & \\
\hline Total mo. of studies & & 25 & & 17 \\
\hline
\end{tabular}

- Sarched via Index Medieus and a comprehensive revilew by Robertson and Dochat from $19044^{\text {th }}$.

$\uparrow$ Odds ratio (or rate ratio) for one or more pregnancies va no piregnanicy ever. Studies presenting odds fatios or rate ratios. for categories of pragnancy were classitied according to the point atimate for the oategory which ineluded 3 progatenclea, and

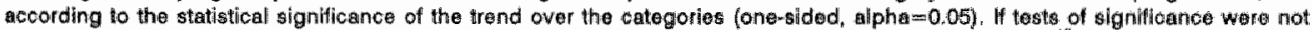

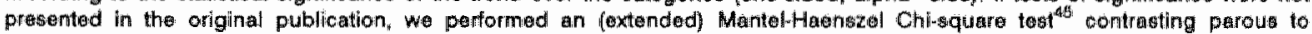

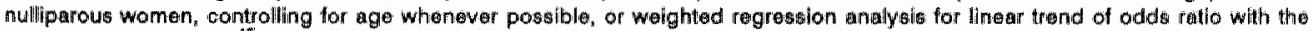
number of pregnanciess

* These studies showed a statistically significant difference of the number of pregnancies botween gallstone cases and conirols, but did not prowide an oddis ratio or data that allowed hts computation.

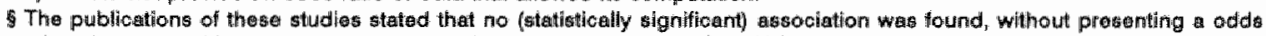

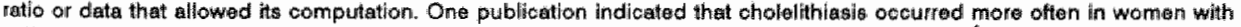
children than in nulliparae up to the age of fifty. whereas the opposite was found atter this age 4 . One study ahowing inegative association between prognancy and gallstone disease? is also includiad in this category.

* Plasults depended on which of the two cantrol graups was congidered in this casemecontrol study.

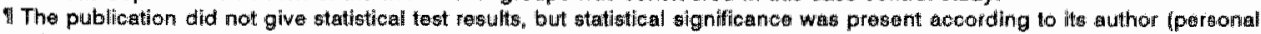
cominunicationi). 
a group of women not made pregnant (all other things being equal). These women should be followed long enough to observe the full-blown effect. Follow-up would only cease when no further effect is observed. Opting for too short a risk period could lead to missing (part of) the effect. A risk period that is too Jong may result in dilution of the effect. An extreme example of the latter is lifetime risk of death in women who have borne children compared to those who have not (both risks equal 1.0 ; rates, however, may differ).

Studies on pregnancy and gallstone disease reported in the literature generally have not specified risk periods. However, there is no doubt that the risk periods implicitly addressed have varied considerably among the study subjects, so that an effect during a limited risk period may easily have been lost in the mass of irrelevant information. Typically, case-control studies have related gallstone disease to pregnancy at any time before diagnosis. Similarly, cohort studies have related the incidence of gallstone disease during follow-up to pregnancy at any time prior to the womens' entry into the cohort. Most publications did not clarify what risk periods had been included. Nevertheless, the information presented suggests that these studies varied with respect to the extent to which relevant risk periods were mixed with irrelevant risk periods. This could explain the large variation in the findings of earlier epidemiologic studies on pregnancy and gal]stone disease.

In the present paper we intend to demonstrate the importance of disentangling the effects of pregnancies in various risk periods in a case-control study. In the imaginary experiment we proposed, we might wish to study the effect of pregnancy separately in women with previous pregnancies and women without a previous pregnancy. Such a prestratification should control for confounding by previous pregnancies. The analysis of our present study likewise aimed at controlling for previous pregnancies. In order to illustrate the effect of the ignoring of risk periods, a conventional analysis is presented first.

\section{METHODS}

\section{Subjects}

Gallstone cases were a series of female patients, aged 20 to 76 , who visited the Academic Hospital Maastricht from 1983 to 1985. All were identified at the register of admissions for cholecystectomy or the register of referral for diagnostic investigation of the gallbladder at the Department of Radiology. In order to restrict the study to new cases, we excluded patients with a history of biliary colic or a medical gallstone diagnosis in the past (longer than one year before referral).

In order to ensure comparability of cases and controls with respect to the referral process, a distinction was made between cases with a compelling indication for hospital referrall ("acute" cases") and cases with less clear-cut indications ("elective" cases). To guide the choice of the control groups, it was argued that residents of the catchment area of the Academic Hospital Maastricht with an intact gallbladder would all be admitted to this hospital if they would present with acute symptoms. Therefore, a random sample from the general population of the catchment area was chosen as the 
control group for acute cases. Women with previous cholecystectomy were to be excluded from this control group.

Contrary to acute cases, elective cases were considered to be selected by hospital referral. Therefore, comparability of hospital referral was sought by choosing a common source for both cases and controls, namely, the register of elective referrals to the Department of Radiology for diagnostic examination of the gallbladder.

Acute cases and population controls. Criteria for an acute referral indication were a new diagnosis of biliary colic, acute cholecystitis, cholangitis or pancreatitis, or obstructive jaundice, as reported in the hospital records of the cholecystectomy patients or in the referral forms of the radiology patients. The control group was composed of women from age-stratified random samples from the municipal population registers of Maastricht and its surroundings. Women reporting a history of biliary colic, radiological gallstone diagnosis, or cholecystectomy were excluded from the population control group.

Elective cases and elective controls. Elective cases were cholecystectomy patients and patients from the radiology register who showed gallstones at ultrasonographic and/or radiographic examination, who did not meet the criteria for an acute referral indication. Elective controls were a sample of patients from the radiology roster in whom no gallstones were found at the examination, and who did not meet the criteria for acute referral indication either. From both groups (elective cases and elective controls) women with a history of biliary colic or a medical gallstone diagnosis in the past (longer than one year before) were excluded.

\section{Measurements}

All participants were interviewed by means of a structured questionnaire about putative risk factors, gastrointestinal symptoms, and medical history. The women were asked how many children they had given birth to (multiple birth counting as one pregnancy), and duration of pregnancies that had ended in abortion, premature birth or still-birth (counted as a pregnancy if duration of pregnancy was more than three months). Using the information on the woman's age at each pregnancy, the occurrence of pregnancies was subdivided into the following periods before interview: $0-5,6-10,11-20$, and 21 years or more.

Measurements were also made of the following risk factors of gallstone disease: age at starting and stopping each period of oral contraceptive use, contraceptive injections and use of perimenopausal hormone pills or injections; and alcohol use and body mass index in the year before interview and 5, 10 and 15 years before. Duration of oral contraceptive use (years) and use of the other hormonal formulas was allocated to the same periods before interview as the pregnancies (e.g., a women who used oral contraceptives from seven to three years ago had contributed two years of oral contraceptive use to the 6-10 year risk period, and three years to the 0-5 year risk period).

\section{Analysis}

The analysis was designed to address the separate effects of pregnancies in the abovementioned periods. For example, the data on pregnancies in the period of 6-10 years before interview convey information on the occurrence of gallstone disease during the 
risk period ranging from 6 to 10 years after pregnancy. Therefore, we will use the expressions "period before interview" and "risk period" interchangeably in this paper.

Rate ratios (incidence density ratios) were estimated by odds ratios ${ }^{46}$, computed in stratified analysis (Mantel-Haenszel method ${ }^{\text {w6 }}$ with test-based $90 \%$ confidence limits ${ }^{47}$ ), and in logistic regression analysis ${ }^{45}$.

The effects of pregnancies for each risk period were analyzed by entering the terms for each risk period in one logistic regression model. In this way the effects of pregnancies on the rate of gallstone disease in each risk period are separated from each other" For example, the effect of pregnancy 6-10 years before gallstone disease occurred is controlled for the confounding effect of earlier and later pregnancies.

A "dose-effect" relation between the number of pregnancies and the rate of gallstone disease was assessed in a nested logistic regression model with the number of pregnancies in each period as interval variables ${ }^{\text {th }}$.

Confounders controlled for in all analyses were referral indication (acute gallstone cases and population controls; elective gallstone cases and elective controls), age (at the time of entry into the study, six categories), and oral contraceptive use. Confounding by oral contraceptive use in the various periods was controlled by entering the variables for duration of oral contraceptive use in each period simultaneously into the logistic regression model. Confounding by the other risk factors was evaluated likewise. Because no important confounding effects of other sex hormones, alcohol use, and body mass index were found, these variables were omitted from the final logistic regression models.

TABLE 2 Number of participants, exclusions and cases and controls according to indication for referral (acute or elective)

\begin{tabular}{|c|c|c|c|c|}
\hline Participants & $\begin{array}{c}\text { Cholecystectomy } \\
\text { patients }\end{array}$ & $\begin{array}{l}\text { Radiodiagnosis } \\
\text { patients }\end{array}$ & $\begin{array}{c}\text { General population } \\
\text { sample }\end{array}$ & Total \\
\hline Candidates & 154 & 201 & 488 & \\
\hline Non-respondents & $24(16 \%)$ & $25(12 \%)$ & $137(28 \%)$ & \\
\hline Excluded & 19 & 24 & 46 & \\
\hline Non-caucasians & & 1 & 2 & \\
\hline Histony of gallstones & $16^{*}$ & $12^{*}$ & $44 t$ & \\
\hline Inconclusive gallstone status & $3 \ddagger$ & 115 & & \\
\hline Subjects for analysis & 111 & 152 & 305 & \\
\hline Acute cases & 85 & 15 & & 100 \\
\hline Population controls & & & 305 & 305 \\
\hline Elective cases & 26 & 15 & & 41 \\
\hline Radiodiagnosis controls & & 122 & & 122 \\
\hline
\end{tabular}

- Galstono diagnosis lomger than one yoar before.

* History of gallstones (6 women), biliary colic (16 women) or choleaystectomy (22 women).

* No gallstomes found during cholacystectomy despite of a positive ultrasound examination.

5. Ultrwound or X-ray exam linconclusive because of technical reasons (3 women), or because of a negative exam in patents with billary collic suggesting gallstones had passed tid women). 
Differences in the results between acute and elective gallstone disease were assessed by testing for statistical interaction between referral indication and the pregnancy variables in the logistic regression analysis. Since no such differences were found, the results are presented for acute and elective gallstone disease combined.

\section{RESULTS}

Table 2 presents the numbers of cases and controls. In all, there were 100 acute cases and 305 general population controls and 41 elective cases and 122 radiodiagnosis controls.

Table 3 shows the rate ratios of pregnancies and gallstone disease, without any specification of risk periods. The overall rate ratio for pregnancy (ever vs. never) was 1.2 (90\% confidence interval 1.02-1.36, logistic regression analysis). A weak dose-effect relation was found. The point estimate of the rate ratio for even five or more pregnancies did not exceed 1.5 .

The results of the logistic regression analysis of gallstone risk in the various risk periods are shown in table 4. An effect was only found for the risk period up to five years after pregnancy ("recent" pregnancy; rate ratio $2.4,90 \%$ confidence interval 1.12 4.96).

Table 5 shows the results of a stratified analysis of recent pregnancy. For such a stratified analysis, the number of strata must not be too large. This limits the possibility to control for many confounders simultaneously. In order to control for previous preg-

TABLE 3 Conventional analysis (ignoring risk periods). Gallstone cases and controls by number of pregnancies, and rate ratios (RA) with $90 \%$ confidence intervals $(90 \%$ Cl)

\begin{tabular}{|c|c|c|c|c|c|c|c|c|}
\hline \multirow{2}{*}{$\begin{array}{l}\text { Number of } \\
\text { pregnancies }\end{array}$} & \multicolumn{2}{|c|}{ Acute } & \multicolumn{2}{|c|}{ Elective } & \multicolumn{2}{|c|}{$\begin{array}{l}\text { Stratified } \\
\text { analysis* }\end{array}$} & \multicolumn{2}{|c|}{$\begin{array}{c}\text { Logistic regression } \\
\text { analysist }\end{array}$} \\
\hline & Cases & Controls & Cases & Controls & AR & $(90 \% \mathrm{Cl})$ & RA & $(90 \% \mathrm{Cl})$ \\
\hline 1 & 9 & 60 & 5 & 19 & 0.8 & $(0.33-1.82)$ & 0.7 & $(0.34-1.26)$ \\
\hline 2 & 28 & 102 & 9 & 30 & 1.1 & $(0.57-1.98)$ & 1.1 & $(0.65-1.89)$ \\
\hline $3-4$ & 29 & 59 & 15 & 43 & 1.4 & $(0.72 \cdot 2.57)$ & 1.5 & $(0.89 \cdot 2.58)$ \\
\hline $5-11$ & 14 & 33 & 6 & 8 & 1.3 & $(0.65-2.59)$ & 1.5 & $(0.79-2.83)$ \\
\hline Any & 80 & 254 & 35 & 100 & 1.2 & $(0.71-1.95)$ & 1.2 & $(1.02-1.36)$ \\
\hline None & 20 & 51 & 6 & 22 & 1.0 & (reference) & 1.0 & (reference) \\
\hline Total & 100 & 305 & 41 & 122 & & & & \\
\hline
\end{tabular}

* Mantel-Haenszel mathod, controlling for age and referral indication. Tast for trand of AR aver the categortes of prepgancy lextended Mamtel-Henszel Chi-square test) $p=0.037$ one-sided.

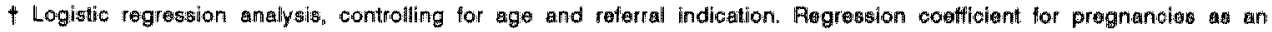
Interwal variable (number of pregnancies) 0.07637 (standard error 0.05305 ), representing a rate ratio per pregnancy of 1.08 (90\% Cl 0.92-1.18), and P.value for a positive dose-eftect relationship $p=0.075$ (one-sidod). 
nancies, pregnancies in the periods $6-10,11-20$ and 21 + years before interview were therefore combined into a variable "earlier pregnancies". The result for recent pregnancy (rate ratio $2.4,90 \%$ confidence interval 1.01-5.86)) was close to that found in the logistic regression andysis presented in table 4.

\section{DISCUSSION}

In a conventional analysis of our casemcontrol study, ignoring risk periods, the rate ratio for the association between pregnancy and gallstone disease was close to unity. When the effects of pregnancy in separate risk periods were disentangled, a substantial effect was noted for the first five years after pregnancy, whereas no effect was found for subsequent periods.

We were not able to exclude subjects with asymptomatic gallstones from the population control group. However, only the presence of gallstones at the moment of exposure (pregnancy) leads to misclassification bias in a dynamic population study such as the present study ${ }^{4}$. In the region were the present study was executed, we have found that the prevalence of asymptomatic gallstones was below $10 \%$ in women of childbearing age $^{48}$. The resulting misclassification can only result in a moderate underestimation of the rate ratio. It cannot explain the discrepancy of the results between the risk period of the first five years and the later risk periods.

TABLE 4 Risk period speciffed, logistic regression analysis. Pregnancy in various risk periods and the rate of gallstone disease. Rate ratios (RR) for pregnancy in each risk period (reference: no pregnancy in that period) with $90 \%$ confidence intervals $(90 \% \mathrm{Cl}){ }^{*}$

\begin{tabular}{|c|c|c|c|c|c|c|c|}
\hline \multirow{2}{*}{$\begin{array}{l}\text { Risk period } \\
\text { (years) }\end{array}$} & \multirow{2}{*}{ Pregnancy } & \multicolumn{2}{|c|}{ Acute } & \multicolumn{2}{|c|}{ Elective } & \multirow{2}{*}{ RR } & \multirow{2}{*}{$(90 \% \mathrm{Cl})$} \\
\hline & & Cases & Controls & Cases & Controls & & \\
\hline \multirow{2}{*}{0.5} & Yas & 13 & 36 & 4 & 6 & 2.4 & $(1.12-4.96)$ \\
\hline & No & 87 & 269 & 37 & 116 & 1.0 & (reference) \\
\hline \multirow{2}{*}{$6-10$} & Yes & 8 & 42 & $y$ & 8 & 0.8 & $(0.40-1.56)$ \\
\hline & No & 92 & 263 & 40 & 114 & 1.0 & (reference) \\
\hline \multirow{2}{*}{$11 \cdot 20$} & Yos & 25 & 108 & 10 & 54 & 0.8 & $(0.52-1.36)$ \\
\hline & No & 75 & 197 & 31 & 68 & 1.0 & (reterence) \\
\hline \multirow{2}{*}{$21+$} & Yas & 53 & 143 & 28 & 71 & 1.0 & $(0.61-1.50)$ \\
\hline & No & 47 & 162 & 13 & 51 & 1.0 & (reference) \\
\hline Total for ea & risk period & 100 & 305 & 41 & 122 & & \\
\hline
\end{tabular}

\footnotetext{
- The regression model included terms for ago, reforral indication, and the varimbles for preginancy in each risk period. In this way age and referral indication are controlled for, as well pregnancy in eacth ather risk period. in the nested logistic regression analysis, no dose-effect relationship between the rate of gallstene disease and the number of pregnancles was found in any of the risk patiods. Wlo substantial difforencess between acute and eloctive gallstone disease were found.
} 
We will now discuss the implications of our findings for the interpretation of previous studies on pregnancy and gallstone disease. Next to that, some specific points related to the ignoring of risk periods are discussed. Finally, we will attempt to explain our results in biological terms.

\section{Previous srudies}

The observed effect of pregnancy in previous studies of gallstone disease was highly variable. Risk periods were not specified in any of the studies, but must have been variable as weil, considering that women entering the study at age 65 , for example, will have had their last pregnancy more than 15 years earlier. More than half of the studies included women of age 65 or over. One study with an undoubtedly short risk period was a retrospective case-control study in women aged 14 to $20^{42}$. This study showed an exceptionally large effect (odds ratio $29.6,90 \%$ confidence interval 11.3-77). In general, young women will have been pregnant in a more recent past than older women. Thus, only in young women will a transient effect of pregnancy be observable. Eight earlier studies have indeed shown a positive association that was mainly restricted to younger

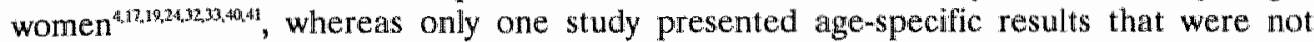
consistent?. The finding of a stronger effect in younger women in earlier studies is consistent with a temporary effect of pregnancy.

\section{Ignoring of risk periods}

Six points related to the ignoring of risk periods in studies of pregnancy and gallstone disease deserve attention. First and foremost, the observed power of a study to exclude a substantial effect is inflated. From the result of the conventional analysis of our study, ignoring risk periods (rate ratio 1.2), one would easily conclude that no strong relation between pregnancy and gallstone disease exists. The confidence interval (which was 1.021.36) might tempt one to conclude that a large effect is excluded with reasonable certain-

TABLE 5 Aisk period" specified" stratified analysis. Rate ratio (RR) of gallstone disease associated to recent pregnancies (i.e. in the last 5 years before interview: reference: no recent pregnancy), with $90 \%$ confidence intervals $(90 \% \mathrm{Cl})^{*}$

\begin{tabular}{|c|c|c|c|c|c|c|c|c|}
\hline \multirow{2}{*}{$\begin{array}{l}\text { Age group } \\
\text { (years)t }\end{array}$} & \multicolumn{2}{|c|}{ Time of pregnancies } & \multicolumn{2}{|c|}{ Acule } & \multicolumn{2}{|c|}{ Elective } & \multirow{2}{*}{ AR } & \multirow{2}{*}{$(90 \% \mathrm{Cl})$} \\
\hline & Earlier & Recent & Cases & Controls & Cases & Controls & & \\
\hline \multirow{2}{*}{$25-44$} & \multirow{2}{*}{ Yes } & Yes & 6 & 12 & 1 & 1 & 3.9 & $(0.91-11.14)$ \\
\hline & & No & $\$ 2$ & 74 & 2 & 29 & 1.0 & (relerence) \\
\hline \multirow{2}{*}{$20-44$} & \multirow{2}{*}{ No } & Yes & 7 & 24 & 3 & 4 & 1.7 & $(0.37-8.12)$ \\
\hline & & No & 8 & 25 & 3 & 12 & 1.0 & (reference) \\
\hline \multicolumn{3}{|l|}{ Total } & 33 & 135 & 9 & 46 & 2.4 & $(1.01-5.86) t$ \\
\hline
\end{tabular}

* Controlling for age (20-24, 25-34, 35-44 years) and referral indicution.

t The table is restricted to age groups with least one woman with recent pregnamcy, because ontly subject in thesu age groupsi contribute intormation to the stratifted analysis.

I Rate ratio for necent pregnancy combining women with and without earlier pregnancies (but stoll controlling lon it). 
ty. Nonetheless, the point estimate for the first five years after pregnancy (rate ratio 2.4) lies outside this interval. This exemplifies that a large study including many subjects who contribute only to irrelevant risk periods will yield an "overall" estimate close to unity, with a confidence interval excluding a major effect. An estimate of an overall effect can only be derived from risk-period specific effects under certain conditions ${ }^{49}$.

A second problem relates to the issue of effect modification by age. Neglect of risk periods may lead to the observation of effect modification by age, since the progression of age as well as the accumulation of risk runs concurrently in time. No biologic explanation has been offered for effect modification by age, except that it reflects a temporary effect of pregnancy on the development of gallstone disease. However, assessment of effect modification by age is an indirect and fallible way to study the temporality of an effect.

A third problem, closely related to the former, concerns dose-effect relation. Dose in the sense of duration of exposure or accumulation of multiple discrete exposures is associated with age. If risk periods are ignored, it is difficult to disentangle the doseeffect relation on the one hand and effect modification by age on the other. Women with multiple pregnancies are mainiy found in the older age groups. For example, among the 60 women with five or more pregnancies in our study, none had been pregnant in the five years before interview, and only two had been pregnant in the period 6-10 years before interview. Hence, no information was available on a transient effect of multiple pregnancies.

A fourth problem we want to comment on is the concept of effect modification by previous exposure. In the bypothetical experiment that we proposed in the Introduction, we stated that we might wish to study the effect of pregnancy separately in women with previous pregnancies and women without a previous pregnancy. One reason for doing so would be control of confounding by previous pregnancies. A second reason would exist if one expected modification of the effect of pregnancy by previous pregnancies. There can be several possibilities. For instance, women who had one or more previous pregnancies without developing gallstone disease might be the ones who are less susceptible to the effect of any subsequent pregnancies. Conversely, a first pregnancy may lead to the formation of gallstones, whereas the next pregnancy makes these gallstones symptomatic. Therefore, from a biologic point of view we expect that the effect of a pregnancy depends on the occurrence of previous pregnancies. However, biologically meaningful effect modification has only been defined in terms of absolute rates or risk $s^{45.50}$.

A fifth problem associated to the ignoring of risk periods deals with control of confounding by other risk factors. For a proper control of confounding, a relevant risk period for the confounder should be chosen. Oral contraceptive use may be a confounder of the relation between pregnancy and gallstone disease, because it probably is a risk factor for gallstone disease itself and is associated with pregnancy. Moreover, the association between oral contraceptive use and pregnancy will vary over time. For example, women will experience no pregnancy in a period in which they use oral contraceptives, but after having stopped they may get pregnant more often than women who never used oral contraceptives. For these reasons, controlling for oral contraceptive use regardless of the time of their use may be insufficient for a proper control of confounding. 
The sixth and last point we want to discuss addresses the superiority of cohort studies over case-control studies. In the Introduction, we presented the experiment as a paradigm for nonexperimental research. Cohort studies are generally believed to be superior over case-control studies, because they bear a closer resemblance to the experiment. This allows observance of the time at which the effect appears after exposure, and follow-up to be sustained until the effect has faded out. This could safeguard against bias caused by too short a risk period. However, a prerequisite is that cohorts are defined by the onset of exposure ('entry cohort ${ }^{36}$ ). For instance, the incidence of gallstones in a cohort of women who have just completed a first pregnancy could be compared to that in a cohort of women of similar age who did not experience a pregnancy. Unfortunately, this requirement is not met in most cohort studies. As an alternative, risk-period specific incidence rates can be estimated in cohort studies in a similar fashion as in case-control studies.

\section{Biologic explanation of transient effect}

The latency period between gallstone formation and clinical symptoms leading to cholecystectomy has been reported to range from 2 to 20 years (mean 12 years) ${ }^{31}$. Our results, on the contrary, suggest a much shorter latency period between pregnancy and the occurrence of clinical gallstone disease. Clinical gallstone disease may develop more rapidly in women of childbearing age, possibly accelerated by pregnancy. Alternatively, pregnancy may cause already existing gallstones to become symptomatic. On the other hand, many studies have shown an association between pregnancy and the presence of asymptomatic gallstones found by screening ${ }^{24,32,34} 40.40$. Therefore, it is unlikely that the only effect of pregnancy is to cause already existing stones to become symptomatic.

It is useful to divide the latency period between pregnancy and clinical gallstone disease into two: 1) the time between pregnancy and the moment that gallstones are fully developed (gallstone formation), and 2) the time between the moment that gallstones are fully developed and the occurrence of biliary symptoms that lead to diagnosis (clinical latency). Ultrasound studies of pregnant women have suggested that biliary sludge and stones may appear and disappear during pregnancy and the puerperium ${ }^{15.52}$. Whether the rate of gallstone formation remains elevated for a longer period is not known, but our results suggest that the duration of such a period does not exceed five years. Why the clinical latency period is also limited to the first five years after pregnancy could be explained in two ways. First, within five years after pregnancy, the appearance and disappearance of gallstones may be balanced, i.e., does not result in a higher prevalence of gallstones after all. From then onwards, the rate of development of clinical gallstone disease should be similar to that in women who had not experienced a pregnancy. This calls for an additional explanation why stones that form in the first five years after pregnancy are different from stones that do not spontaneously disappear and that cause the prevalence of gallstones to rise with age. Possibly, these stones are more purely consisting of cholesterol. Second, during or shortly after pregnancy, gallstones develop that cannot spontaneously disappear anymore. These stones would have to become rapidly symptomatic if the pool of gallstones that will ever lead to symptoms is to be depleted within five years. This calls for an additional explanation of why these stones become more rapidly symptomatic than suggested by the mean latency of 12 years 
in the study mentioned before $\mathrm{e}^{51}$. A later pregnancy or oral contraceptive use may play a role in the development of symptoms of gallstones that had formed during an earlier pregnancy. It has been postulated that similar mechanisms that lead to gallstone formation play a role in the development of symptoms. Altered biliary motility may cause impaction of the stone, and bile cholesterol supersaturation may lead to cholecystitis by chemical irritation of biliary mucosa that is already damaged by a stone ${ }^{53}$. Our finding that the effect of a recent pregnancy on the occurrence of clinical gallstone disease was higher when a previous pregnancy had oecurred (table 5) is consistent with this notion.

In summary, pregnancy transiently increases the rate of gallstone formation, and it may in addition enhance the development of symptoms when gallstones already exist.

To conclude, we want to stress the importance of specification of risk periods in etiologic studies. Ignoring of risk periods may explain part of the variability in the tindings of studies on pregnancy and the risk of gallstone disease. We found an effect that was limited to some five years after pregnancy.

\section{REFERENCES}

1. Mayes LC, Horwitz RI, Feinstein AR. A collection of 56 topics with contradictory results in casecontrol research. Int J Epidemiol 1988; 17:680-5.

2. Braunwald $\mathrm{E}$, Isselbacher $\mathrm{KJ}$, Petersdorf $\mathrm{RG}$, eds. Harrison"s Principles of internal medicine (11th ed.) New York: McGraw-Hill, 1987:1360.

3. Comess $I_{w_{n}}$ Bennett $P$, Burch $T$. Clinical gallbiadder disease in Pima Indians. $\mathrm{N}$ Engl $\mathrm{J}$ Med $1967 ; 277: 894-8$.

4. Horn G. Observations on the aetiology of cholclithiasis. Brit Med J 1956;2,732-7.

5. Richardson JD, Scutchfield FD, Proudfoot $\mathrm{WH}_{\text {, }}$ et al. Epidemiology of gallbladder disease in an Appalachian community. Public Health Reports 1973;88:241-6.

6. Wheeler M, Hitls LL, Laby B. Cholelithiasis: a clinical and dietary survey. Gut 1970;11:430-7.

7. Sampliner RE, Bennet PH. Comess LV, et al. Gallbladder disease in Pima indians. New Eng J Med 1970;283:1358-64.

8. Howat JMT, Jones CB, Schofield PF, Gall-stones and oral contraceptives. J Int Med Res 1975;3:59-62.

9. Williams $\mathrm{CN}$, Johnston $\mathrm{JL}_{4}$, Weldon KLM. Prevalence of gallstones and gallhtadder discase in Canadian Micmac Indian women, Can Med Assoc J 1977;117:758-60.

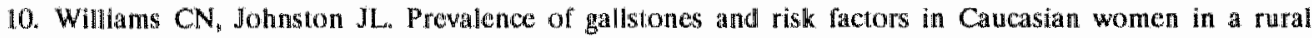
Canadian community. Can Med Assoc J 1980;120:664-8.

11. Diehl AK, Stern MP, Ostrower VS, et al. Prevalence of clinical gallbiadder disease in MexicanAmericam, Anglo, and Black women. Southern Med J 1980;73:438-43.

12. Pixley F, Mann J. Dietary factors in the aetiology of gall stones: a case control study, Gut $1988 \% 29: 1511.5$

13. Catoli A, Spigariol F, Zambelli $C$, et al. Epidemiologia della malatia litiasica biliare. Prevalenza e fattori associati in una popolazione diabetica (Italian). Recenti Progressi in medicina 1987;78:59-62.

14. Walker AR, Segal I, Posner R, et al. Prevalence of gallstones in elderly black women in Soweto, Johannesburg, as assessed by ultrasound. Am J Gastroenterol 1989;84:1383-5.

15. Maringhini $A$, Pia Mareeno $M$, Lanzarone $F$, et al. Sludge and stones in gallbladder after pregnancy. Prevalence and risk factors. J Hepatol 1987;5:218-23.

16. Friedman GD, Kannel WB, Dawber TR. The epidemiology of gallbladder disease: Observations in the Framingham study. J Chron Dis 1966;19:273-92. 
17. Brummer $P$. On the correlation between gallbladder disease, obesity, and pregnancy. Ann Med Int Fenniae 1949;38:106-9.

18. Boss L. Gallbladder disease in the Alaskan native populations. Ph.D Dissertation. Howolulu: University of Hawaii, 1981.

19. Scragg RKR, McMichael AJ, Seamark RF. Oral contraceptives, pregnancy, and endogenous oestrogen in gall stone disease - a case-control study. Brit Med J 1984,288:1795-252.

20. Diehi AK, Rosenthal M, Hazuda HP, et al. Socioecononic status and the prevalence of clinical gallbladder disease. IJ Chron Dis 1985;38:1019-26.

21. Wysowski DK, Goldberg EL, Comstock GW, et al. A study of a possible association between breast cancer and gallbladder disease. Am J Epidemiol 1986;123:532-43.

22. Strom BL, Ravikiran MPH, Tantragouri $\mathrm{N}$, et al. Oral contraceptives and other risk factors for gallbladder disease. Clin Pharmacol Ther 1986;39:335-41.

23. Maclure $\mathrm{KM}$. Hayes $\mathrm{KC}$, Colditz $\mathrm{GA}$, elt al. Weight, diet, and the risk of symptomatic gallstones in middle-aged women. N Engl J Med 1989;321:563-9.

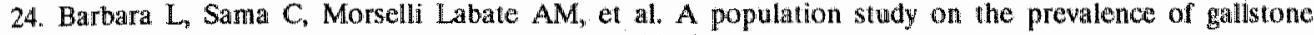
disease: the Sirmione study. Hepatology 1987;7:913-7.

25. Maurer KR, Everhart JE, Knowler WC, et al. Risk factors for gallstone disease in the Hispanic populations of the United States. Am J Epidemiol 1990;131:836 44.

26. Sichieri $\mathrm{R}$, Everhart JE, Roth HP. Low incidence of hospitalization with gallbladder disease among blacks in the United States. Am J Epidemiol 1990;131:826-35.

27. Kritz-Silverstein D, Barrett-Connor E, Wingard DB. The relation between reproductive history and cholecystectomy in older women. J Clin Epidemiol 1990;43:687-92.

28. Van der Linden $W$. Some biological traits in female gallstone-disease patients, Acta Chir Scand 1961; Suppl 269:1-94.

29. Peterson $\mathbb{R}$. Gall-stones during pregnancy and the puerperium. Surg Gynecol Obstet 1910;11:1-11.

30. Burnett W. The epidemiology of gallstones. Tijdschr Gastroenterol 1971;14:79-89.

31. Layde PM, Vessey PM, Yeates D. Risk factors for gall-bladder disease: a cohort study of young women attending family planning clinics. J Epidemiol Cormun $\mathrm{H} 1982 ; 36: 274-8$.

32. Jorgensen T. Gall stones in a Danish population: fertility period, pregnancies, and exogenous female sex hormones. Gut 1988;29:433-9.

33. Blümel $P_{n}$ Zur Statistik des Gallensteinleidens (German). Bruns Beitrage zur KJinischen Chirurgie 1931;152:221-34.

34. Bernstein RA, Werner LH, Rimm AA. Relationship of gallbladder disease to parity, obesity and age. A study of 62,739 weight-conscious women. Health Services Reports 1973;88:925-36.

35. Ahlberg J. Serum lipid levels and hyperlipoproteinaemia in gallstone patients. Acta Chir Scand 1979;145:373-7.

36. Sastic JW, Glassman Cl. Gallbladder disease in young women. Surg Gynecol Obstet 1982;155:209-11.

37. Knowler $\mathrm{WC}_{\mathrm{C}}$ Carraher $\mathrm{MJ}$, Pettiu DJ, et al. Epidemiology of cholelithiasis in the Pima Indians. IIn: Capocaccia $\mathbb{L}$, Ricei $G$. Angelico $F$, et al., Ed. Epidentology and prevention of gallstone disease. Lancaster: MTP Press, 1984,15-22.

38. Krislo $V$, Sorf $M$, Sulek $\mathbb{P}$, et al. The influence of pregnancies on the prevalence of cholelithiasis (Czech). Cuechoslovenska gynekologie 1986;51:10-3.

39. Lee SS, Wasiljew BK, Lee MJ. Gallstones in women younger than thirty. J Clin Gastroenterol $1987 ; 9: 65$-9.

40. The Rome group for epidemiology and prevention of cholelithiasis (GREPCO). The epidenilology of gallstone disease in Rome, Italy. Part II. Factors associated with the disease. Hepatology 1988;8:90713.

41. Thistle JL, Eckhart KL, Nensel RE, el al. Prevalence of gallbladder disease among Chippewa Indians. Mayo Clin Proc 1971:46:603-8.

42. Honore LH. Cholesterol cholelithiasis in adolescent females. 1ts connecion with obesity, parity, and oral contraceptive use - a retrospective study of 31 cases. Arch Surg 1980;115:62-64.

43. Khuroo MS, Mahajan $R$, Zargar SA, et al. Prevalence of biliary tract disease in India: a sonographic study in adult population in Kashmir. Gut 1989;30:201-5. 
44. Robertson $\mathrm{HE}$, Dochar GR. Pregnancy and gallstones. Collective rewew. International Abstract of Surgery $1944 ; 78: 193 \cdot 204$.

45. Rothman KJ. Modern epidemiology. Boston: Litlew Brown and company, 1986.

46. Miettinen OS. Theoretical epidemiology. Principles of occarrence research in medicine. New York: Wiley, 1985 .

47. Miettinen O. Design options in epidemiologic research - an update. Scand J Work Eny Hea 1982; (suppl 1$)$ in $7-14$

48. Thijs C, Knipschild P, van Engelshowen J. The prevalence of gallstone disease in a Dutch population. Scand J Gastroenterol $1990 ; 25: 155-60$.

49. Mietlinen OS, Caro JJ. Principles of nonexperimental assessment of excess risk, with special reference to adverse drug reactions. J Clin Epidemiol 1989:42:325-31.

50. Miettinen OS. Causal and preventive interdependence. Elementary prificiples. Scand $J$ Work Env Hea $1982,8: 159-68$.

51. Mok HY, Druffel ER, Rampone WM. Chronology of cholelithiasis, dating gallstones from atmospheric radiocarbon produced by nuclear bomb explosions. N Engl J Med 1986;314:1075-7.

52. Maringhimi $A$, Clambra $M_{3}$ Baccellere $P$, el al, Slludge, stones, and pregnancy [tetter]. Gastroenterology 1988;95:1160-1.

53. Matolo NM, LaMorte WW, Wolfe BM. Acute and chronic cholecystitis. Surg Clin North Am 1981:61:875-83. 


\section{5 \\ DE PIL - REVIEW}

\section{Veroorzaken orale anticonceptiva galblaasziekte? \\ - een review}

Om te bepalen hoe groot het risico op galblaasziekte is ten gevolge van het gebruik van orale anticonceptiva, werden systematisch alle publicaties van gecontroleerd epidemiologisch onderzoek verschenen tot april 1991, opgezocht en geëvalueerd.

Onder de 24 studies ( 26 publicaties) doorstonden er negen de toets van een kritische evaluatie met betrekking tot de onderzoeksopzet. De indruk werd gevestigd dat door restrictie tot deze negen onderzoeken tegelijkertijd het probleem van publicatievertekening omzeild werd.

De gegevens tonen dat het gebruik van orale anticonceptiva is geassocieerd met een gering en tijdelijk verhoogd risico op het optreden van galblaasziekte. De dosis-effect relatie suggereert dat moderne laag-gedoseerde veiliger zijn dan oudere preparaten, echter een klein effect kan niet worden uitgesloten. Zes geselecteerde onderzoeken waarin vrouwen waren gescreend voor asymptomatische galstenen toonden opvallend gelijke resultaten (odds ratios van 1,3 tot 1,4). Statistische pooling hiervan leverde een odds ratio van 1.36 (95\% betrouwbaarheidsinterval 1.15-1.62) voor ooit ten opzichte van nooit pilgebruik.

Vanuit pragmatisch oogpunt blijft de vraag in welke mate een extra risico op galblaasziekte wordt overvleugeld door de effectievere zwangerschapswoorbehoeding door orale anticonceptiva in vergelijking met andere voorbehoedingsmethoden. 


\title{
DO ORAL CONTRACEPTIVES CAUSE GALLBLADDER DISEASE? A REVIEW OF EPIDEMIOLOGIC STUDIES
}

\author{
Carel Thijs and Paul Knipschild \\ Department of Epidemiology and Biostatistics, \\ Rijksuniversiteit Limburg
}

\begin{abstract}
To assess the risk of gallbladder disease due to oral contraceptive use, Controlled epidemiologic studies published until December 1990 were systematically searched and reviewed. Among 24 situdies (26 publications), nine could stand the test of critical appraisal with respect to validity. Restriction to these studies was judged to avoid publication bias at the same time. The evidence shows that oral contraceptive use is associated with a slightly and transiently increased rate of gallbladder disease. A dose-effect relation was indicated, suggesting that modern low-dose oral contraceptives are safer than older formulas, but an effect cannot be excluded. The results of the six selected studies in which asymptomatic women were screened for gallstones were strikingly similar (odds ratios ranging from 1.3 to 1.4). Pooling of these results yielded an odds ratio for ever vs. never OC use of 1.36 (95\% confidence interval 1.15-1.62). From a pragmatic point of view, the question remains to what extent an excess risk of gallbladder disease is overnuled by a lower risk of gallbladder disease due to more effective prevention of pregnancies when compared to other contraceptive methods. (Submitted for publication)
\end{abstract}

\section{INTRODUCTION}

Epidemiologic studies in the 70 s have indicated a higher risk of gallbladder disease associated with oral contraceptive (OC) use $^{1.7}$. Later research, however, yielded conllicting results ${ }^{8-26}$. This inconsistency raised several questions, addressed in this review:

1. Were the older studies systematically biased by flaws in their design (or are the newer studies less valid)?

2. Was there a tendency at the time of the earlier studies that only "positive" studies were found interesting enough for publication?

3. How should the evidence in the studies be weighted?

4. Are there explanations for the inconsistencies, e.g. is the effect absent in later studies because modern low dose OCs lack an effect on gallbladder disease? 
Because OCs are widely used, a small effect of $O C$ use on the occurrence of gallbladder disease may have a considerable impact on public health, even if the effect is small. Therefore we undertook a systematic review of controlled epidemiological studies on the subject, addressing the questions raised here.

\section{METHODS}

Original publications were searched in Medline (1983-1991/3) on CD-Rom. Earlier publications were found via references in later publications and review articles ${ }^{27-31}$. The review was restricted to controlled epidemiologic studies of gallbladder disease (except gallbladder cancer). The studies were compared with respect to their main findings (the results over all subgroups together). Instead of performing a formal meta-analysis, we tried to explicate our subjective evaluation, so that the reader can make other judgements if he or she wishes.

When confidence limits were lacking in the original publication, they were computed from the raw data or from statistical parameters presented, using the test-based method $^{32}$, unless stated otherwise. Pooling of odds ratios from selected studies was preformed by weighing the natural logarithms of the odds ratios with the inverse of their variances ${ }^{33}$, the latter computed from standard errors of logistic regression, or estimated from confidence intervals or chi-squares.

Effects in subgroups were only considered in the light of specific hypotheses.

\section{RESULTS}

Twenty-six publications were found, concerning 24 studies. The studies were classified by study design. Four studies were follow-up studies (table 1). After the initial publication of two large cohort studies, the results of extended follow-up appeared some years later (the Royal College of General Practitioners Oral Contraceptives Study (Royal-I and II) ${ }^{2,12}$ and the Oxford/ Family Planning Association Contraceptives Study (Oxford-I and II) ${ }^{5,13}$ ). Eight studies were case-control studies with new cases of gallstone disease (table 2). One publication reported two case-control studies with one and the same case series $^{15}$. These are included as separate studies in table $2^{15 \mathrm{~A} ; \mathrm{B}}$. In nine studies healthy women were screened for gallstones by ultrasound or X-ray (screening studies, table 3). The remaining four studies related prevalent cases of gallbladder disease to $O C$ use $e^{8,10,18}$ or gallbladder disease and $\mathrm{OC}$ use reported at any moment during a two year study period $^{19}$ (table 4).

The main fundings are shown in the last columns of the tables. The results vary considerably (rate ratios or odds ratios ranging from 0.3 to 6.0 ). Odds ratios or rate ratios of 2.0 or greater were only observed in studies reported up to 1982 (five out of 1.4 studies, 4 statistically significant); thereafter no odds ratio of rate ratio greater than 1.4 was observed. The Royall study and the Oxford study both showed a decrease of the effect at extended follow-up (relative risk decreasing from 1.3 to 1.1, and from 1.6 to 1.3 , respectively, table 1$)^{1,5,12,13}$. 


\section{Internal Validity of the Studies}

In the next section we give our ratings of the validity of the studies. The table summarize these: + denotes adequate management of bias, - inadequate or no management of bias, and 0 bias not likelly.

\section{Confounding}

Among possible confounders of the association between $\mathrm{OC}$ use and gallbladder disease, pregnancy deserves special attention. Women who use OCs will not get pregnant, whereas non-users may; pregnancy itself increases the risk of galJbladder disease. The design that best safeguards against confounding by pregnancy was encountered in the Oxford study (table 1). This study compared the rates of gallbladder disease associated with use of OCs, intrauterine devices or pessary. This hopefully made the contrasts comparable

TABLE 1 Follow-up studies on oral contraceptive (OC) use and gallbladder disease Rate ratios (RA) with $95 \%$ confidence intervals $(95 \% \mathrm{Ci})$

\begin{tabular}{|c|c|c|c|c|c|c|c|c|}
\hline \multirow[t]{3}{*}{ Author } & \multirow[t]{3}{*}{ Year } & \multirow{3}{*}{$\begin{array}{l}\text { Population at admission: duration of } \\
\text { follow-up } \\
\text { Dlagno:sis (Wo. of cases: } \\
\text { OC use }\end{array}$} & \multicolumn{5}{|c|}{ Validity ratings: } & \multirow[t]{3}{*}{$\operatorname{RA}^{\mathrm{a}}(95 \% \mathrm{Cl})$} \\
\hline & & & \multicolumn{4}{|c|}{ Corrtounding Detaction } & Publication & \\
\hline & & & \multicolumn{2}{|c|}{$\begin{array}{l}\text { Contra- } \\
\text { imdication }\end{array}$} & \multicolumn{3}{|c|}{ Rlegistration } & \\
\hline Fioyely $=1^{2}$ & 1974 & $\begin{array}{l}\text { OC usears and never-users; } 4 \text { yrs } \\
\text { Selforeported gallbledder disease (201) } \\
\text { Current'never OC use }\end{array}$ & + & + & + & + & + & $1.3(1.0-1.8)^{\star}$ \\
\hline $\begin{array}{l}\text { Oxtord-1 } \\
\text { Noside } 5\end{array}$ & 1976 & 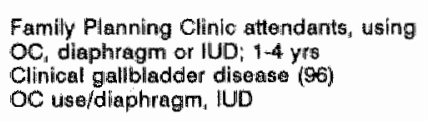 & + & + & + & $+*$ & + & $1.6(0.9 \cdot 2.7)^{b_{3}}$ \\
\hline Famcharan ${ }^{11}$ & 1981 & $\begin{array}{l}\text { Subscribers to health insurance; } 5-9 \text { yrs } \\
\text { Clinical gallbladder disease }(304) \\
\text { Currentinaver OC ue }\end{array}$ & + & 0 & - & + & + & $0.8(0.6-1.3)^{\mathrm{c}}$ \\
\hline Royalu|l & 1902 & $\begin{array}{l}\text { OC war's and noverusers: } 10 \text { yro } \\
\text { Soll-reported gallibladder disease (768) } \\
\text { Curent/non*use }\end{array}$ & + & 0 & 0 & + & + & $1.1(1.0-1.3)$ \\
\hline 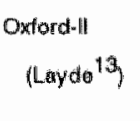 & 1982 & 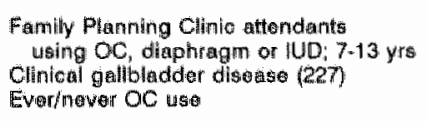 & + & 0 & + & + & + & $1.3(0.9-1.7)^{d_{k}}$ \\
\hline Sithiori 25 & 1900 & 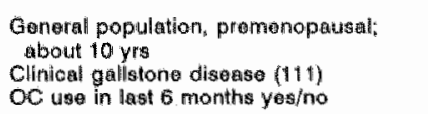 & - & 0 & - & + & + & $1.2(0.8 \times 1.8)$ \\
\hline
\end{tabular}

a All stidilo had a person-time type of analysita.

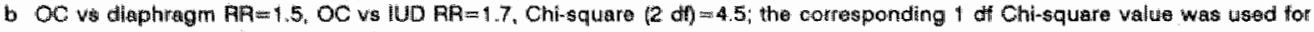
the tert-besad $95 \%$-Cil of the combined RA.

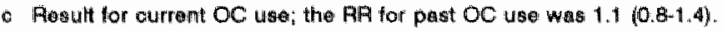

Chilsquare for the test-based $35 \%$.Cl was computed from the Pavalue pressented $(p=0.13)$. 
with respect to the occurrence of pregnancies, Remaining differences were controlled for in the analysis. An example of a study that did not pay attention to confounding by pregnancies was a small case-control study by Honore ${ }^{7}$ in women aged 14 to 20 , yielding a relative risk of 2.5 (table 3 ). Possibly, women who had been preguant at such a young age used OCs thereafter, whereas women who were not yet sexually very active neither used $\mathrm{OCs}$, nor got pregnant. If so, the results for $\mathrm{OC}$ use may largely be due to confounding by pregnancy, since the effect of pregnancy in this study was of sufficient strength to do so (relative risk 29.6). The tables indicate which studies paid attention to confounding by pregnancy (or parity) at all (rated + if yes; - if not).

TABLE 2 Case-control studies on oral contraceptive (OC) use and incidence of gallstones found by screening. Odds ratios (OR) with $95 \%$ confidence intervals (95\% Cl)

\begin{tabular}{|c|c|c|c|c|c|c|c|c|}
\hline \multirow[t]{3}{*}{ Author } & \multirow[t]{3}{*}{ Year } & \multirow{3}{*}{$\begin{array}{l}\text { Cases (No): controlls (No): age } \\
\text { Type of analysis, OC use }\end{array}$} & \multicolumn{5}{|c|}{ Validity ratings: } & \multirow[t]{3}{*}{ OR $(95 \% \mathrm{Cl})$} \\
\hline & & & \multicolumn{3}{|c|}{ Confounding Datection } & \multicolumn{2}{|c|}{ Publication } & \\
\hline & & & \multicolumn{2}{|c|}{ 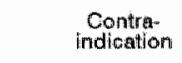 } & \multicolumn{3}{|c|}{ Fegistration } & \\
\hline Boston" & 1973 & $\begin{array}{l}\text { Clinical gallstone disease (212); Acute } \\
\text { illness or olective surgery (842); } 20-34 \text { yrs } \\
\text { Standardized, ever/nover use }\end{array}$ & - & + & + & + & - & $2.0(1.4-2.8)$ \\
\hline Stolley ${ }^{3}$ & 1975 & $\begin{array}{l}\text { Biliany tract surgery (85): hospital controls } \\
\text { (12:17); } 15-49 \text { yrs } \\
\text { Cfude, OC wse in past } 2 \text { yrs yes/no }\end{array}$ & - & + & + & + & - & $2.0(1.2-3.2)$ \\
\hline Howat ${ }^{4}$ & 1975 & $\begin{array}{l}\text { Surgery for gallstone disease }(50) \text {; minor } \\
\text { surgery or treuma controls }(50) ; 20-45 \text { yrs } \\
\text { Crude, oc use }>6 \text { months yes/no }\end{array}$ & $+{ }^{a}$ & 0 & - & - & - & $6.0(2.6-14)$ \\
\hline Ahliberg ${ }^{6}$ & 4979 & $\begin{array}{l}\text { Positiwe oholecystogram (42); minor } \\
\text { suingery (56); } \leq 30 \text { yrs } \\
\text { Crude, } O C \text { use }>6 \text { months yas/no }\end{array}$ & + & 0 & - & - & + & $b$ \\
\hline Hononé ${ }^{7}$ & 1980 & $\begin{array}{l}\text { Surgery for gallstone disease }(31) \text {; surgany } \\
\text { for tonsillitis or nasal : septum dewiation } \\
\text { (112); 14-20 yrs } \\
\text { Mantel-Haenszel, OC use over/never }\end{array}$ & - & 0 & - & - & - & $2.5(0.8-7.1)$ \\
\hline Sastic ${ }^{14}$ & 1982 & 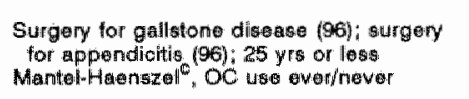 & - & 0 & - & - & - & $2.5(1.1 \cdot 6.2)$ \\
\hline Serage ${ }^{15} \mathrm{~A}$ & 1984 & $\begin{array}{l}\text { Clirical gailstone disease }(200) \text {; hospital } \\
\text { controls (234) }<29 \text { to }>60 \text { yrs } \\
\text { Mantel-Hentent, OC use ever/hever }\end{array}$ & + & 0 & + & $+d$ & + & $0.7(0.5-1.0)$ \\
\hline Scragg ${ }^{15} \mathrm{~B}$ & 1984 & $\begin{array}{l}\text { Clinical gallstone disease }(200) \text {; general } \\
\text { population controls }(182) \text {; }<29 \text { to }>60 \mathrm{yr} \\
\text { Martel-Haerzzel, OC use everinever }\end{array}$ & + & 0 & - & - & + & $0.5(0.3-0.9)$ \\
\hline
\end{tabular}

* Matched on parity, but no matched analysis: RR may be underestimated.

b No date presented. The authors stated that among non-parous women OC Le was moro provalent in cases than in aentrols (p< $<0.05$, and that this was mot found when comparing those who had buen pregnant.

- Mamtel-Haenszel odds ratio (with Comfield's $95 \%$ confidence intervals) from stratthed tables that aould be rocomstituted from the tables presented, controllimg for obesity and parify.

d Casse were interviewed betore the diagnostis examination; controls were haid lignorant of the hypothesis during the intervilow.

a The authors reported that logistic regression analysis inelicated no confounding by parity. 
Another potential confounder is age of sexual maturity. The rate of gallstone development increases with early sexual maturity ${ }^{23}$. Only two studies controlled for it ${ }^{15,23}$.

TABLE 3 Screening studies on oral contraceptive (OC) use and gallstones found by screening using ultrasound or oral cholecystography. Odds ratios (OR) with $95 \%$ confidence intervals $(95 \% \mathrm{Cl})$

\begin{tabular}{|c|c|c|c|c|c|c|c|c|}
\hline \multirow[t]{3}{*}{ Author } & \multirow[t]{3}{*}{ Yor } & \multirow{3}{*}{$\begin{array}{l}\text { Population acreaned; age } \\
\text { Diarnceris (No. of cases) } \\
\text { Type of anatysis, OC use }\end{array}$} & \multicolumn{5}{|c|}{ Waltdity ralings: } & \multirow[t]{3}{*}{ OR $(95 \% \mathrm{Cl})$} \\
\hline & & & \multicolumn{3}{|c|}{ Confounding Detection } & \multicolumn{2}{|c|}{ Publication } & \\
\hline & & & \multicolumn{2}{|c|}{$\begin{array}{l}\text { Cantre- } \\
\text { indication }\end{array}$} & \multicolumn{3}{|c|}{ Registration } & \\
\hline Wilitams ${ }^{9}$ & 1980 & $\begin{array}{l}\text { Gieneral population; } 15-50 \text { yrs } \\
\text { Giallstonesi and cheleystectomy (20) } \\
\text { Parcentage OC users (ever/never })^{\text {a }}\end{array}$ & - & 0 & + & + & + & $1.0(0.3-3.2)$ \\
\hline GREPCO 16 & 1984 & $\begin{array}{l}\text { Ciwll serwants; } 20-49 \text { yrs } \\
\text { Gallotones and cholecyatectomy (38i) } \\
\text { Logistic regreasion, OC use over/never }\end{array}$ & + & 0 & + & + & + & $1.3(0.8-2.3)$ \\
\hline$P|x| a y^{17}$ & 1985 & $\begin{array}{l}\text { Sample from general practice; } 40-96 \text { yrs } \\
\text { Gallstonas and eholecystectomy (156) } \\
\text { Mantel-Haanszel, no details on OC use }\end{array}$ & $?$ & 0 & + & + & + & $b$ \\
\hline Sort ${ }^{20}$ & 1987 & $\begin{array}{l}\text { Haalthy young wamen, meam age } 28 \\
\text { Gallstones: eholecystectemy excluded (26) } \\
\text { Raw datad, oc wse ever/never }\end{array}$ & $t^{\circ}$ & 0 & + & + & + & $1.3(0.6-2.9)$ * \\
\hline Maringhinit 21 & 1987 & 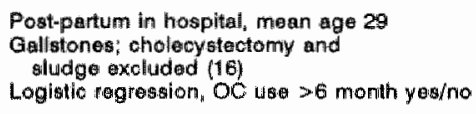 & 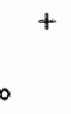 & 0 & + & + & + & $1.4(1.0-1.8) *$ \\
\hline Barbara. $^{22}$ & 1987 & $\begin{array}{l}\text { General population, } 18-65 \text { yrs } \\
\text { Gallstones and cholicystectomy (132) } \\
\text { Mantel-Hegerszel method "OC use ever/never }\end{array}$ & $?$ & 0 & + & + & + & $0.7(0.5-1.3)$ \\
\hline Jorgensen ${ }^{23}$ & 1988 & $\begin{array}{l}\text { General population, } 30,40,50 \text { and } 60 \text { yrs } \\
\text { Gallstones and cholocystectomy (202) } \\
\text { Logistio regrestion, OC use overinaver }\end{array}$ & + & 0 & + & + & + & $1.4(1.0-2.0) *$ \\
\hline Maurerer & 1990 & 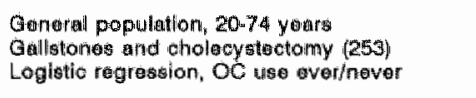 & + & 0 & + & + & + & $1.4(1.0-2.0)^{0 *}$ \\
\hline Pannwitit ${ }^{26}$ & 1900 & $\begin{array}{l}\text { General population, 12-24 yrs } \\
\text { Gallstones and cholecystectomy (43) } \\
\text { Stratified data!, OC use ewar/mever }\end{array}$ & + & 0 & + & + & + & $1.4(0.5-4.1) *$ \\
\hline
\end{tabular}

Pooled (only studies indicated by *)

a The data presented allowed eomputation of crivde odds ratio and chi-square.

b The publication stated that there was no rolation betwoen OC use and gallstone disease, but no data were prosented.

4. The study was restricted to parous women.

Crude odds ratio and chil-square computed from $2 \times 2$ table, combining categories of duration of oC use (no trend with duration observed).

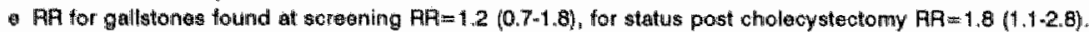

* Rolatiwa risk (Mantol-Haenszel odds ratio) computed from a stratified table presented in the original paper, controlling for familly history, pregnancy (owormever) and body mass index. 
The biases that are considered next follow from the subjective assessment of $O C$ use, and the variable and chronic symptomatology of gallbladder disease. They all depend in some way or another on the suspicion of $O C$ use as a risk factor for gallbladder disease. Four studies had been conducted before suspicion was raised ${ }^{1-3,5}$, as evidenced by the statements about the objective of the studies in their publications. We therefore judge that these studies are not affected by the biases considered next (in the tables rated + ).

\section{Confounding by contraindication}

Women with a known high risk of gallbladder disease (e.g. with a positive family history, or gross obesity) might tend to look for other ways of contraception in order to avoid a further increase of the risk by $\mathrm{OC}$ use. As a result, $\mathrm{OC}$ users would be the women with at relative low risk of gallbladder disease, compared to non-OC users. Studies ignoring this would underestimate the effect of $O C$ use, or even suggest a protective effect. However, gallbladder disease as an adverse effect of OC use has always been overshadowed by the effects on cardiovascular disease and cancer. Therefore, we do not expect that confounding by contraindication leads to a severe underestimation of the effect (rated 0 ).

\section{Biased detection of gallbladder disease}

A second bias is induced when suspicion of gallbladder disease as a side-effect tends to enhance the detection of gallstones in $\mathrm{OC}$ users with vague abdominal complaints. Gallstones are so common ${ }^{34}$ that cholecystography or ultrasound of the gallbladder will show

TABLE 4 Other studies on oral contraceptive (OC) use and gallbladder disease, with uncertain time relation. Odds ratios (OR) with $95 \%$ confidence intervals $(95 \% \mathrm{Cl}$ )

\begin{tabular}{|c|c|c|c|c|c|c|c|c|}
\hline \multirow[t]{3}{*}{ Author } & \multirow[t]{3}{*}{ Year } & \multirow{3}{*}{$\begin{array}{l}\text { Study design, agi of subjects } \\
\text { Diagnosis (No. of cases) } \\
\text { Type of analysis, OC use }\end{array}$} & \multicolumn{5}{|c|}{ Validity ratings: } & \multirow[t]{3}{*}{ OR $(95 \%$ Cll $)$} \\
\hline & & & \multicolumn{3}{|c|}{ Confounding Detection } & \multicolumn{2}{|c|}{ Publication } & \\
\hline & & & \multicolumn{2}{|c|}{$\begin{array}{l}\text { Contra- } \\
\text { indication }\end{array}$} & \multicolumn{3}{|c|}{ Registration } & \\
\hline Dieht ${ }^{8}$ & 1980 & $\begin{array}{l}\text { Rewiew of madieal records of Family Health } \\
\text { Center population, } 15-59 \text { y/s } \\
\text { Chinical gallstone disease: ever (107) } \\
\text { Log-linear regression, OC use givernever }\end{array}$ & h & 0 & - & - & + & a \\
\hline Peatritit ${ }^{10}$ & 1981 & 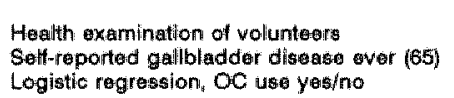 & - & 0 & - & - & + & $0.7(0.4-1.2)$ \\
\hline Wysowiskil $^{18}$ & 1986 & 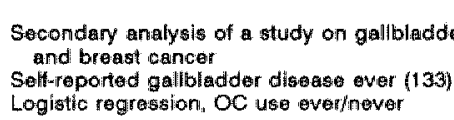 & Ser & 0 & $=$ & - & + & $0.3(0.1-1.1)$ \\
\hline Strom ${ }^{19}$ & 1986 & 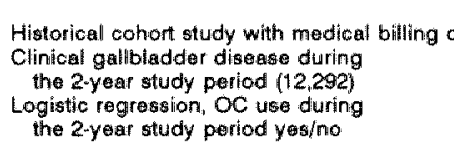 & data $t^{b}$ & o & - & + & - & $1.1(1.1-1.2)$ \\
\hline
\end{tabular}

\footnotetext{
The publiciation stated that there was no relation between OC use and gallatone discase, but no deta were presented.

b Only comtroling for pregnancios that had occumed during the 2-year otudy period.
} 
gallstones in a considerable proportion of women, even when their complaints are not due to the stones. In the screening studies no detection bias can occurr (rated + ). The case-control study by Scragg included a control group of patients who were referred for a radiodiagnostic exam of the gallbladder ${ }^{19 \mathrm{~A}}$. In this way selective referral of the cases is balanced by equally selective referral of the controls (rated + ).

The decreasing effect found at extended follow-up in the Royal study and the Oxford study ${ }^{12,13}$ cannot be explained by detection bias, since such a bias can only lead to a spurious rellation between the drug and the disease (rated + ). An additional reason why detection bias is not probable in the Royal study is its finding at extended follow-up of an effect of OCs on cholecystitis only, not on gallstone disease ${ }^{12}$. Detection bias will not occur easily if a disease is so severe that it always comes to medical attention, like acute cholecystitis.

All other studies performed at the time that $O C$ use was suspected for affecting gallstone risk may be affected by detection bias (rated -).

\section{Biased registration of $\mathrm{OC}$ use}

A third form of bias occurs when the suspicion of an adverse effect leads to better registration of $\mathrm{OC}$ use in women with known gallbladder disease than in women with other conditions. Notorious are case-control studies in which the information on OC use is extracted from the hospital records, without $O C$ use being recorded systematically. Doctors may notice $\mathrm{OC}$ use as a risk factor in patients with gallbladder disease, and record it. By contrast, they may ignore $O C$ use in patients with diseases that are not known to be related to OC use. If the latter patients are selected as a control group, a spurious relation between $O C$ use and gallbladder disease will result. We found at least two examples (table 2): case-control studies that contrasted information from the hospital records of cholecystectomy patients to that of patients operated for tonsillitis or nasal septum deviation (Honore ${ }^{7}$ ), or appendicitis $\left(\right.$ Sastic $^{14}$ ). The publication of the casecontrol study by Howat suggests a similar problem. It does not tell how the information on $O C$ use was collected, only that information from cholecystectomy patients was contrasted to that of patients who had visited the hospital for surgery or minor trauma. These three studies showed the largest relative risks encountered $(2.5,2.5$ and 6.0 , respectively; rated -).

Such a bias is precluded in the following situations (rated +): OC use is recorded before the disease occurs (the follow-up studies, table 1); or the interview on $O C$ use is performed before the diagnostic examination in asymptomatic people (the screening studies, table 3) or in patients with similar symptoms (the case-control study by Scragg among patients who were referred for a radiodiagnostic exam of the gallbladder ${ }^{15}$, table 2). In the study Strom (table 4) the reporting of OC use and gallbladder disease (to the health insurance company) was independent from each other (rated + ). The remaining studies may have been affected by registration bias if performed when suspicion of OCs was already raised (rated -). 


\section{Publication Bias}

Are the studies that we have found representative for all studies of the relation between OC use and gallbladder disease? Or are they a selection, e.g. only studies that showed a statistically significant positive relation? Such a selection may occur in the following situations.

When a large data-base is screened for all possible relations, of which only the statistically significant ones are reported, many of the reported relations will be positive by chance. The first publication was such a selective publication from a data screening project, the Boston Collaborative Drug Surveillance Programme', which related a gamut of diseases to the use of a mass of drugs ${ }^{35}$ (Boston, table 1). Likewise, publication bias may occur when many secondary analyses are performed of data that were collected for other purposes, and only positive ones are published. The study by Stolley (table 2) was recognizable as resulting from such a secondary analysis ${ }^{3}$. The study by Strom (table 4 ) explored the possibility to monitor adverse drug reactions with medical insurance data. According to the authors, some established relations were chosen to test this possibility, OC use and gallbladder disease being one of the first ${ }^{19}$.

Another possibility of publication bias exists if many "quick and dirty" studies with a low power are undertaken to confirm an adverse drug reaction, and if only the statistically significant positive studies are published. The two small case-control studies by Howat ${ }^{4}$ and Sastic ${ }^{14}$ were recognizable as such (table 2). The small case-control study by Honoré ${ }^{7}$ reporting a non-significant association between gallstone disease and $\mathrm{OC}$ use may have been saved from oblivion because it also reported an extremely strong and statistically significant association between gallstone disease and parity (and obesity; table 2).

The six studies that we judged to have emerged from selective publication (in the tables rated -) comprised all studies with a relative risk of 2.0 or more. The study by Strom reported a weak effect (relative risk 1.1) that nevertheless reached statistical significance owing to the large data $\operatorname{set}^{1 \text { \% }}$.

Publication bias does not occur in large-scale studies of effects of OC use, in which all relations studied were reported. We identified three such studies: the Royal and the Oxford studies, and the Walnut Creek Contraceptive Drug Study, reported by Ramcharan (rated + , table 1). The remaining studies were studies of risk factors of gallbladder disease or gallstones. The whole body of publications from these studies (which we have collected systematically) give the impression that all factors studied have been reported reasonably systematically (rated + ).

\section{Weighting the Evidence}

As we have seen so far, many studies had serious flaws in their design. Furthermore, there may be considerable publication bias in favor of "positive" studies on OC use and gallbladder disease. Disregarding the "positive" studies for this reason would not be appropriate, however, because we would by ourselves introduce a selection of the 
literature based on the results. Fortunately, selection of the studies without negative ratings with respect to validity automatically excludes all studies with a negative rating for publication bias.

The 9 studies (11 publications) selected in this way are marked with an asterisk (*) in the tables. With one exception, the relative risks were above 1.0 (range 1.1-1.6; 4 times statistically significant ${ }^{2,12,23,24}$ ). The exception was the study by Scragg, showing a relative risk of 0.7 (statistically significantly below 1.0$)^{15 \mathrm{~A}}$. This inconsistency is evaluated in the second part of this review.

In the rest of this review, only the selected studies are considered. An exception is made for the study by Strom ${ }^{19}$. In our wiew, it deserves attention because the consistent dose-effect relation shown by this study does not easily result from chance variation alone, neither from other biases.

The results of the six selected screening studies were very similar, odds ratios ranging from 1.3 to 1.4 (table 3). Pooling of the results yielded an odds ratio of 1.36 (95\% confidence interval 1.15-1.62).

\section{Specific Hypotheses Explaining the Inconsistencies}

\section{Is the effect restricted to biliary inflammation?}

The Royal study distinguished between inflammatory disease of the biliary system (cholecystitis and (occasionally) cholangitis, ICD 575) and gallstones without clear inflammation (cholelithiasis, ICD 574). In the initial report, no clear difference was found ${ }^{2}$, but at extended follow-up the effect was restricted to cholecystitis. For current OC use the relative risks were: cholecystitis 1.31 ( $95 \%$ confidence interval 1.06-1.62); and cholelithiasis $0.95(0.71-1.27)^{12}$. For former OC use the results were comparable.

The only other study that made a similar distinction was the study by Strom ${ }^{19}$. In spite of the large number of cases, it did not show a difference between cholecystitis and cholelithiasis.

If $O C$ use would only cause the formation of gallstones that become rapidly symptomatic, no effect should be found on the prevalence of asymptomatic gallstones found by screening. The same holds if $\mathrm{OC}$ use would only cause inflammation of the gallbladder if gallstones already exist (without itself causing gallstone formation). This is not confirmed, as two positive screening studies only included asymptomatic gallstones (Sorf, Maringhini, table 3); analyses of two other screening studies by subgroup of asymptomatic gallstones and cholecystectomy were less conclusive (GREPCO: odds ratios $(95 \% \mathrm{Cl}) 1.45(0.75-2.80)$ and $1.17(0.49-2.81)$, respectively ${ }^{16}$; Maurer: $1.2(0.7-1.8)$ and $1.8(1.1-2.8)$, respectively $\left.{ }^{24}\right)$.

To conclude, there is little evidence that OC use causes biliary inflammation, other than by causing the formation of gallstones.

\section{Does the effect depend on age?}

In the study by Strom the effect of OC use decreased with age ${ }^{19}$. Two other siudies presented age-specific results, one showing a similar trend ${ }^{15}$, the other a trend in opposite direction ${ }^{23}$. The next section offers an explanation for age-dependency. 


\section{Is the effect transient?}

In the Royal study the initial effect disappeared after extended follow-up. The authors postulated that the rate of gallbladder disease was only transiently increased after the start of $O C$ use $\mathrm{e}^{12}$. This was confirmed by an analysis of the effect by duration of $O C$ use in women who still used OCs at the end of the follow-up period. The rate of gallbladder disease was only increased if $O C$ use had started 5 years earlier or more recently, while it was maximal after 3 years' duration (rate ratio 1.3). In women who had used OCs for more than 7 years, the rate even dropped below that of the non-users ${ }^{12}$. These findings gave rise to the following hypothesis. During the first years of $\mathrm{OC}$ use the rate of gallbladder disease is raised. When women who are susceptible for getting gallbladder disease indeed get the disease as a result of $O C$ use, the remaining population in the analysis are relatively insusceptible women. In non-OC users no such selection of susceptibles takes place. This would explain the lower rate of the disease at longer duration of $\mathrm{OC}$ use. The results of the Oxford study showed a similar pattern ${ }^{13}$.

In none of the other studies risk periods were sufficiently specified to detect a transient effect. However, the decrease of the effect with age in the study by Strom may be explained by a transient effect, since the proportion of $O C$ users who only recently started $O C$ use must have been highest in the younger age groups ${ }^{19}$. A similar explanation may hold for the findings in the study of Scragg, which showed a negative association between OCs and the rate of gallbladder disease. In women aged 29 or less a positive relation was found (rate ratio $1.5,95 \%$ confidence interval $0.2-9.8$ ), whereas rate ratios were below 1.0 in older age groups ${ }^{15 \mathrm{~A}}$. The latter may have resulted from selection of insusceptible women by earlier OC use. However, this explanation is not entirely satisfactory, because we judge that the rate ratios in the higher age groups (which ranged from 0.5 to 0.7 ) were too low to have resulted from such a selection.

It should be noted that selection on susceptibility only occurs when measuring incidence density (rate ratio in the follow-up studies, table 1 , and odds ratio in the casecontrol studies, table 2), not when measuring prevalence (odds ratios in the screening studies, table 3). The prevalence of gallstones results from the accumulation of the rate of gallstone development over time, and gallstones are assumed seldom to disappear spontaneously. The results of the screening studies are in line with this.

\section{Is the effect dose-dependen?}

The first studies were performed at a time when OCs contained considerably larger doses of estrogen and progestin than nowadays pills. Sub-fifty $\mathrm{OCs}$ (containing $50 \mathrm{\mu g}$ of estrogen or less) became available about 1975. If only higher dosed OCs lead to gallbladder disease, this could explain why later studies did not find an effect anymore. Two studies have evaluated a dose-effect relation. In the Royal study the rate ratio in the third year of $O C$ use was 1.4 at $50 \mathrm{mg}$ of estrogen, and 3.2 at 100 or $150 \mu \mathrm{g}^{12}$. However, these results were based on a few cases only. The study by Strom confirmed a dose-effect relation with estrogen dose: relative risks ( $95 \%$ confidence intervals) were for estrogen doses of $<50 ; 50 ;$ and $>50 \mathrm{\mu g}$ : $1.0(0.9-1.04) ; 1.1(1.06-1.19) ; 1.2(1.08-1.35)$ (trend $\mathrm{p}=0.001)^{19}$. In younger women the dose-effect relation was more pronounced, whereas it was absent in older women. This age-dependency may be due to transiency of 
the effect. In none of the studies was it possible to control for different effects of the progestin component of these formulas.

\section{DISCUSSION}

In 24 epidemiologic studies of $\mathrm{OC}$ use and gallbladder disease the results varied highly. Nine of these studies could stand the test of critical appraisal with respect to internal validity. The same studies were judged to pose no problems of publication bias. These stidies showed a much narrower range of estimates of the effect. The evidence confirmed a transient effect of $\mathrm{OC}$ use on the rate of gallbladder disease, with a doseeffect relation with estrogen dose. However, it is not clear whether this is due to the estrogen component, or to the progestin component, or to differences in the generic characteristics of the components, because the progestins used have changed concurrently with the estrogens. The inconsistency between the study by Scragg and the other selected studies was (at least partly) explained by selection on susceptibility in combination with a transient effect. In studies not affected by such selection (screening studies), the results were strikingly homogeneous, justifying statistical pooling (pooled odds ratio 1.36 (95\% confidence interval 1.15-1.62)).

In general, the studies reviewed failed in specifying risk periods. This hampers disentangling the effects of decreasing dose in time, duration of OC use, transiency of the effect, and increasing prevalence of gallstones by age. Moreover, it may hamper control of confounding by time-dependent factors such as pregnancy and age of sexual maturity. In a previous study we analyzed the effect of ignoring risk periods in studies of pregnancy and gallbladder disease. We showed that the effect of pregnancy is limited to some 5 years after pregnancy, and that this effect is missed if risk periods are ignored ${ }^{36}$. Any further study of OC use and gallbladder disease should more properly specify risk periods.

If the pros and cons are to be weighted when making a choice between OCs and alternative contraception, the adverse effects should be expressed as excess risk (attributable risk) rather than relative effect measures. Only the excess risk of symptomatic gallstones is clinically relevant, because many gallstones remain asymptomatic throughout life. Only recently have the principles of estimating excess risk been outlined in a mathematically correct way ${ }^{37}$. It requires risk period specific estimates of rate ratios (incidence density ratios), weighed by the background incidence in each stratum, derived from follow-up of the base population ${ }^{37}$. None of the studies reviewed here met these requirements, so that no estimate of excess risk can be made.

The suggested selection of susceptibility implies that resuming $O C$ use after some years without having had gallstone disease needs not be associated with an additional excess risk. The same may hold for $\mathrm{OC}$ use starting after a pregnancy. None of the studies offered data to evaluate these contentions. However, Ahlberg stated that among non-parous women $\mathrm{OC}$ use was more prevalent in cases than in controls $(\mathrm{p}<0.05)$, and that this was not found when comparing those who had been pregnant ${ }^{6}$.

The latency period between gallstone formation and symptomatic gallstone disease has been reported to average 12 years (range $2-20$ years) ${ }^{38}$. The transiency of the effects 
of $O C$ use within 5 or 10 years suggested in our review sharply contrasts to this. It suggests that $O C$ use enhances the development of symptoms of already existing gallstones, with or without enhancing gallstone formation. It has been speculated that mechanisms involved in the formation of gallstones (increased biliary cholesterol saturation and decreased gallbladder motility) also play a role in gallbladder inflammation ${ }^{39}$. However, no support for this explanation has been found in the present review. In a study of the effect of obesity we found a much shorter latency period as well (about five years) ${ }^{40}$.

The effect of $\mathrm{OC}$ use on gallstones formation is (at least partly) mediated by an increase of biliary cholesterol saturation ${ }^{27,31}$, and possibly also by alteration of gallbladder function ${ }^{41-43}$. Serum lipids may play a role in the first mechanism ${ }^{44}$. Many modern $\mathrm{OCs}$ are designed to have no adverse influence on serum lipids (i.e. no decrease of high density lipoprotein or increase of triglyceride levels). Avoidance of such influence may prevent gallstone formation. However, too little is known about the causality of the relation between serum lipids and biliary cholesterol saturation to be confident of this. A metabolic study has shown that low-dose OCs increase bile saturation ${ }^{45}$. This effect was judged to be quantitatively similar to that of older high-dose pills ${ }^{45}$. No influence was observed on gallbladder motility. The quantitative importance of either mechanism of the development of gallstones, and their role in the development of symptoms is not known. Therefore, although the epidemiologic evidence suggests less effect of modern low dose OCs than older OCs, an effect on gallbladder disease cannot be excluded at the moment.

In this review we contrasted OC use to non-use of OCs. It was assumed, as was done in most studies under review, that non-use meant either "no contraception" or "alternative contraception". In any case, it was conceived that pregnancies would not occur during $O C$ use, and neither during non-use (hence pregnancy was considered a confounding factor). This is justified from an explanatory point of view. By contrast, from a pragmatic point of view, it is more interesting to know the risk of gallbladder disease when OCs are used, compared to alternative methods of contraception. OC use may be more effective in preventing pregnancies than other methods, and may thereby prevent gallbladder disease due to pregnancy. The risk of gallstone disease associated to pregnancy far outreaches the effect of $\mathrm{OC}$ use (in the study quoted before the rate ratio for pregnancy was 2.4 in the first 5 years after pregnancy, $95 \%$ confidence interval $1.12-4.96)^{36}$. This may diminish the excess risk associated with $O C$ use itself, and may even turn it into a protective net effect. From such a viewpoint, the studies should not have controlled for the occurrence of pregnancies from the start of contraception onward. None of the studies adopted such a pragmatic point of view.

\section{REFERENCES}

1. Boston Collaborative Drug Surveillance Programme. Oral contraceptives and venous thromboembolic discases, surgically confirmed gallbladder disease, and breast tumors. Lancet 1973; i:1399-1404.

2. Royal College of General Practioners Oral Contraceptives and Health. London: Pitman Medical, 1974:57-9. 
3. Stolley PD, Tonascis JA, Tockman MS, Sarwell PE, Rutledge AH, Jacobs MP. Thrombosis with lowestrogen pral contraceptives, Arn J Epidemiol 1975;102:197-208.

4. Howati JMT, Jones CB, Schofield PF. Gall-stones and oral contraceptives. I Int Med Res 1975;3:59. 62.

5. Vessey $M$, Doll $R$, Péto $R$, Johnson $B$, Wiggins $P$. A longterm follow-up study of women using different mehods of contraception - An interim report I Biosoc Sci 1976:8:373-427.

6. Aliberg \%. Serum lipid levels and hyperlipoproteinaemia in gallstone patients. Acta Chir Scand $1979 ; 145: 373 \times 7$.

7. Honore LH. Cholesterol cholellithisis in adolescent females. Its connection with obesity, parity and oral contraceptives use - A retrospective study of 31 cases. Arch Surg 1980;115:62-4.

8. Dieh AK, Stern MP, Ostrower VS, Friedman PC. Prevalence of clinical gallbladder disease in Mexican-American, Anglo and Black Women. Southern Medical Joumal 1980; 73:438-41.

9. Williams $C N$, Johnston $J L$. Prevalence of gallstones and risk factors in Caucasian women in a rural Canadian community. Canadian Medical Association Journal 1980;120:664-8.

10. Petiti $D B$, Friedman $G D$, Klatsky AL. Association of a history of gallbladder disease with a reduced concentration of high-densily-lipoprotein cholesterol. N Engl I Med 1981;304:1396-8.

11. Rameharan S, Pellegrin FA, Ray R, Hsu J-P. The Walnut Creek Contraceptiwe Drug Study (vol.III). Bethestla: National Insilutes of Health, 1981.151-52.

12. Royal College of Generall Practioners' Oral Contraception Study. Oral contraceptives and gallbladder disease. Lancet 1982;ii:957-9.

13. Layde PM, Vessey MP, Yeates D. Risk factors for gall-bladder disease: a cohort study of young women attending family planning clinics. $J$ Epidemiol Comm Health 1982;36:274-8.

14. Sastic JW, Glassman CI. Gallbladder disease in young women. Surg Gyn Obstet 1982;155:209-11.

15. Scragg RK.R, McMichael AJ, Seamark RF. Oral contraceptives, pregnancy, and endogenous oestrogen in gall stone disedse -a case control study. Brit Med J 1984;288:1795-9.

16. Rome Group for the Epidemiology and Prevention of Cholellithisis (GREPCO). Prevalence of gallstone disease in an Italian adult female population. Am J Epidemiol 1984;119:796-805.

17. Pixley F, Wilson D, McPherson K, Mann J. Effect of vegetarianism on dewelopment of gall stones in women. Brit Med J 1985;291:11-12.

18. Wysowski DK, Goldberg EL, Comstock GW, Diamond EL A study of a possible association between breast cancer and galtbladder disease. Am J Epidemiol 1986;123:532-43.

19. Sitrom BL, Tamragouri RN, Morse ML, et al. Oral contraceptives and other risk factors for gallbladder discase. Clin Pharmacol Ther 1986;39:335-41.

20. Sorf $M$, Krislo $V$, Sulek $\mathbb{P}$, et al. Do oral contraceptives increase the risk of development of cholelithiasis? Ceskoslovenska Gynaekologie 1987,52:434-7.

21. Maringhini A, Marcenó MP, Lanzarone F, et al. Sladge and stones in gallbladder after pregnancy. Prewalence and risk lactors. I Hepatol $1987 ; 5: 218-23$.

22. Barbara $L$, Sama $C$, Morselli l.abate $A M$, at a population study on the prevalence of gallstone discase: the Sirmione study. Hepatology 1987;7:913-7.

23. Jorgensen T. Gall stones in a Danish population: fertility period, pregnancies, and exogenows female sex hormones. Gut 1988,29,433.9.

24. Maurer KR, Everhart JE, Knowler WC, Shawker TH, Roth HP. Risk factors for gallstone disease in the Hispanic populations of the United States. Am J Epidemiol 1990;131:836 -44.

25. Sichieri R, Everhart JE, Roth HP. Low incidence of hospitalization with gallbladder disease among blacks in the United States. Am I Epidemiol 1990; 131:826-35.

26. Pannwilz $H, N$ urnberg $D$, Berndt $H$. Zur Epidemiologie von Gallenblasensteinen (GS) bei jungen Frauen. Leber Magen Darm 1990;20:198-92,194.

27. Bennion LJ, Grundy SM. Medical Progress; Risk factors for the development of cholelithiasis in man (first of two parts). New Engl J Med 1978;299:1161-7.

28. Cohen MM. Chronic Disease Reviews No. 1.- Gallstones. Chronic Diseases in Canada $1982 ; 3($ Suppl):35-57.

29. Strom BL, West SI. The epidemiology of gallstone disease. In: Cohen S, Soloway RD, Eds. Gallstones. New York: Churchill Livingstone, 19851-26. 
30. Pixley F. Epidemiology. In: Bateson MC, ed. Galistone disease and is managenent. Lancaster: MTP Press, 1986:1-23.

31. Scragg RKR. Aetiology of cholesterol gallstones. In: Bateson MC ed. Gallstone disease and its management. Lancaster: MTP Press, 1986:25-55.

32. Miettinen OS. Estimability and estimation in case-referent studies. Am J Epidemiol 1976;103:226-35.

33. Fleiss JL. Statistical methods for rates and proportions. New York John Wiley and sons, 1973: 116.

34. Thijs $C$, Knipschild $P$, van Engelshoven $J$. The prevalence of gallstone disease in a Dutch population. Scand J Gastroenterol 1990;25:155-160.

35. Feinstein AR. Para-analysis, faute de mieux, and the perils of riding on a data barge. J Clin Epidemiol $1989,42: 929-35$.

36. Thijs $\mathrm{C}_{\mathrm{b}}$ Knipschild $\mathrm{P}$, Leffers $\mathrm{P}$. Pregnancy and gallstone disease - an empirical demonstration of the importance of specification of risk periods. Am J Epidemiol 1991;134:186-95.

37. Miettinen $O S$, Cairo $J J$. Principles of non-experimemtal assessment of excess risk, with special reference to adverse reactions. J Clin Epidemiol 1989;42:325-31.

38. Mok HY, Druffel ER, Rampone WM. Chronology of cholelithiasis, dating gallstones from atmospheric radiocarbon produced by nuclear bomb explosions. N EngI J Med 1986;314:1075-7.

39. Matolo NM, Lamorte WW, Wolfe BM. Acute and Chronic Cholecystitis. Surg Clin North Am $1981 ; 61: 875-83$.

40. Thijs C, Knipschild P, Leffers P. Are gallstones caused by obesity or by slimming? (accepted September 1991)

41. Braverman DZ. Johnson ML, Kern F. Effects of pregnancy and contraceptiwe steroids on gallbladder function. $N$ Engl J Med 1980;302:362-4.

42. Everson GT, McKinley C, Lawson M, Johnson M, Kern F. Gallbladder function in the human fentle: effect of the ovulatory cycle, pregnancy, and contraceptive steroids. Gastroenterology 1982;82:711-9.

43. Kern $F$, Everson GT, DeMark B, et al. Biliary lipids, bile acids and gallbladder function in the human female: effects of contraceptive steroids. J Lab Clin Med 1982;99:798-805.

44. Thijs $C T$, Knipschild $P G$, Brombacher $P$. Serum lipids and gallstone disease, a case-control study. Gastroenterology 1990:99:843-9.

45. Werf SDJ van der, Berge Henegouwen GP van, Ruben AT, Palsma DMH. Biliary lipids, bile acid metabolism, gallbladder motor function and small intestinal transit during ingestion of a sub-fifty oral contraceptive. J Hepatol 1987; 4: 318-26. 



\section{6 \\ DE PIL}

\section{Orale anticonceptiva en het optreden van galsteenziekte - een patiënt-controle onderzoek}

Het gebruik van orale anticonceptiva (de "pil") heeft mogelijk een voorbijgaand effect op het optreden van galsteenziekte. Dit werd geëvalueerd in een patiënt-controle onderzoek met 100 patiënten met acute galsteenziekte en 305 controlepersonen uit de algemene bevolking, en 41 electieve galsteenpatiënten en 122 controlepersonen die een electief radiodiagnostisch onderzoek van de galblaas hadden ondergaan. Risicoperiode-specifieke incidentiedichtheidsratio's werden geschat in logistische regressie-analyses, gecontroleerd voor de matching factoren leeftijd en verwijsindicatie. In een poging om te controleren voor vele andere mogelijke confounders werden verscheidene covariabelen in het regressiemodel opgenomen die met mogelijk met pilgebruik verband houden (leeftijd van menarche en menopauze; zwangerschap; hormoonsubstitutie; Quetelet-index; nietontbijten, alcoholgebruik; suikerziekte).

Wanneer alleen voor de matching factoren leeftijd en verwijsindicatie werd gecontroleerd, waren de resultaten als volgt: voor de risicoperiode van 0 tot 5 jaar was de incidentiedichtheidratio 1,5 ( $90 \%$ betrouwbaarheidsinterval $0,79-2,93$ ); voor de 6-10 en 11-20 jaars risicoperiodes respectievelijk $1,2(0,67-2,14)$ en $1,1(0,69-1,72)$. Bij controle voor de andere covariabelen veranderden de resultaten sterk: de incidentiedichtheidsratio's voor de repectievelijke risicoperiodes werden $1,2,1,7$ en 1,0 .

In eerder onderzoek werden risicoperiodes onvoldoende gespecificeerd. Ons onderzoek suggereert dat schattingen van het effect van pilgebruik sterk kunnen worden vertekend door risicoperiode-specifieke confounding. 


\title{
ORAL CONTRACEPTIVE USE AND THE OCCURRENCE OF GALLSTONE DISEASE - A CASE-CONTROL STUDY
}

\author{
Carel Thijs, Pieter Leffers and Paul Knipschild \\ Department of Epidemiology and Biostatistics \\ Rijksuniversiteit Limburg
}

ABSTRACT - We evaluated an hypothesized transient effect of oral contraceptive use on the occurrence of gallstone disease in a case-control study. Control subjects were groupmatched to cases of gallstone disease with respect to referral indication (acute vs elective) and age. The study comprised 100 acute cases and 305 general population controls, and 41 elective cases and 122 radiodiagnosis controls. Risk period specific rate ratios were estimated by logistic regression analysis, controlling for the matching factors age and referral indication. Several female fertility factors and life-style risk factors were evaluated for their confounding effects. When only matching factors were controlled for, the results were consistent with the hypothesis. The rate ratio for the 0-5 year risk period was $1.6190 \%$ confidence interval 0.83 2.79), and for the 6-10 and 11-20 year risk periods 1.2 (0.68-2.15) and 1.1 (0.69-1.75), respectively. Further evaluation showed stibstantial risk period specific confounding. After controlling for the covariables the rate ratios were $1.2,1.7$ and 1.0 for the respective risk periods. Earlier studies on oral contraceptive use and gallbladder disease did not specify risk periods. The results suggests that previously reported estimates of the effect of oral contraceptive use on the occurrence of gallstone disease may be strongly biased by risk period specific confounding. (Submitted for publication)

\section{INTRODUCTION}

Recently, a large number of epidemiologic studies of the effect of oral contraceptive use on the occurrence of gallstone disease were reviewed". Most studies did not specify risk periods, so that they could easily have missed a hypothesized transient effect ${ }^{2}$. Such an effect was suggested by the Royal College of General Practitioners' Oral Contraception (RCGP-OC) Study when the risk of gallbladder disease was assessed in relation to the duration of current oral contraceptive use (compared to never-use) ${ }^{3}$. The rate of gallbladder disease was only increased in the first five years after the start of oral contraceptive use (maximal rate ratio 1.3 after three years). After about seven years the rate was even lower than the reference rate. The latter was explained by supposing that 
women who did not get gallbladder disease in the first years after the start of oral contraceptive use were relatively insusceptible.

The present case-control study evaluates the risk period specific effects of oral contraceptive use on the occurrence of gallstone disease.

\section{METHODS}

\section{Subjects}

Gallstone cases were a series of female patients, aged 20 to 76 , who visited the Academic Hospital Maastricht in 1983 to 1985. All were identified at the register of admissions for cholecystectomy or the register of referral for diagnostic investigation of the gallbladder at the Department of Radiology. In order to restrict the study to new cases, we excluded patients with a history of biliary colic or a medical gallstone diagnosis in the past (longer than one year before referral).

In order to ensure comparability of cases and controls with respect to the referral process, a distinction was made between cases with a compelling indication for hospital referral ("acute" cases) and cases with less clear-cut indications ("elective" cases). To guide the choice of the control groups, it was argued that residents of the catchment area of the Academic Hospital Maastricht with an intact gallbladder would all be admitted to this hospital if they would present with acute symptoms. Therefore, an random sample from the general population of the catchment area was chosen as the control group for acute cases. Women with previous cholecystectomy were to be excluded from this control group.

Contrary to acute cases, elective cases were considered to be selected by hospital referral. Therefore, comparability of hospital referral was sought by choosing a common source for both cases and controls, namely the register of elective referrals to the Department of Radiology for diagnostic examination of the gallbladder.

Acute cases and population controls. Criteria for an acute referral indication were a new diagnosis of biliary colic, acute cholecystitis, cholangitis or pancreatitis, or obstructive jaundice, as reported in the hospital records of the cholecystectomy patients, or in the referral forms of the radiology patients. The control group was composed of women from age-stratified random samples from the municipal population registers of Maastricht and its surroundings. Women reporting a history of biliary colic, radiological gallstone diagnosis, or cholecystectomy were excluded from the population control group.

Elective cases and elective controls. Elective cases were cholecystectomy patients and patients from the radiology register who showed gallstones at ultrasonographic and/or Xray examination, who did not meet the criteria for an acute referral indication. Elective controls were a sample of patients from the radiology roster in whom no gallstones were found at the examination, and who did not meet the criteria for acute referral indication either. From both groups (elective cases and elective controls) women with a history of biliary colic or a medical gallstone diagnosis in the past (longer than one year before) were excluded. 


\section{Measurements}

All participants were interviewed by means of a structured questionnaire about putative risk factors, gastrointestinal symptoms, and medical history. Recordings were made of the following risk factors of gallstone disease: age at starting and stopping of each episode of oral contraceptive use, contraceptive injections and use of perimenopausal hormone pills or injections; age of pregnancies; and alcohol use and body mass index in the year before interview and 5,10 and 15 years before.

\section{Analysis}

A subdivision into the following risk periods was made: $0-5,6-10,11-20$, and 21 years or more. Considerations for the choice of cutpoints between risk periods were: 1) the RCGP-OC study showed that the rate of gallbladder disease was raised in the full first five years of oral contraceptive use, but diminished at longer duration; the exact moment of the rate dropping below the reference rate was somewhere between 6 and 10 years' duration; 2) about 20 years before the subjects entered the study (1965) oral contraceptives were introduced, and 10 years later (1975) sub-fifty oral contraceptives became available, so that the 11-20 year risk period concerned oral contraceptives with higher estrogen dose only, the other risk periods include modern low-dose oral contraceptives.

Years of oral contraceptive use were allocated to the corresponding periods before interview (e.g. a woman who used oral contraceptives from seven to three years ago, had contributed two years of oral contraceptive use to the 6-10 year risk period, and three years to the $0-5$ year risk period).

The analysis was designed to address the separate effects of oral contraceptive use in the above mentioned periods. For example, one year of oral contraceptive use in the period of 6-10 years before interview conveys information on the occurrence of gallstone disease during the risk period ranging from 6 to 10 years after that year of oral contraceptive use. Therefore, we will use the expressions "period before diagnosis" and "risk period" interchangeably in this paper.

The effects of oral contraceptive use in terms of rate ratios (incidence density ratios) for each risk period were analyzed by logistic regression analysis "with terms for duration of oral contraceptive use in each risk period in one logistic regression model. In this way the effects of oral contraceptive use on the rate of gallstone disease in the risk periods are separated from each other.2. For example, the effect of oral contraceptive use 6-10 years before the occurrence of gallstone disease is controlled for the confounding effect of earlier and later oral contraceptive use.

In all analyses the matching factors were controlled for (i.e. six age strata as in the age-stratified population sample, and referral indication (acute cases and population controls ws. elective cases vs. elective controlsy).

Evaluation of confounding. For some of the confounders age-specific data were available. They were allocated to risk periods $(0-5,6-10,11-20$ and $21+$ years $)$ in the same manner as oral contraceptive use: early or late menarche; pregnancies; other sex hormone use; early or late natural or artificial menopause, or indeterminate menopause (the latter in case of hysterectomy without ovariectomy before natural menopause). For other confounders data were available for several moments in the past (recent; and 5, 10 
and 15 years before interview: body mass index, skipping breakfast, and alcohol use), or anytime (diabetes mellitus, history of gallstones in parents). No relevant confounding was considered to be present if the joint confounding ratio (the ratio between the estimates of the rate ratio found when controlling for all potential confounders, compared to the rate ratio controlling for none of the confounders except the matching factors) remained between 0.98 and 1.02 in each of the risk periods.

It is debatable whether change of body mass after the start of oral contraceptive use should be considered as a confounder. It is not justified to control for it if oral contraceptive use affects body mass, and if change of body mass is an intermediate factor (or an indicator of an intermediate factor, e.g. related to biliary cholesterol saturation"). Therefore, only control for body mass index at the outset of oral contraceptive use is justified, whereas additional control for body mass index during or after oral contraceptive use may obscure the effect. This was evaluated in separate analyses, omitting body mass index after the start of each risk period from the logistic regression model.

Effect modification by previous exposure. The RCGP-OC study suggested the hypothesis that women who did not get gallstone disease during the first few years after the start of oral contraceptive use are relatively insusceptible for getting gallstone disease after further oral contraceptive use ${ }^{3}$. This implies that the results for the $0-5$ year risk period should depend on previous oral contraceptive use: an increased rate of gallstone disease if oral contraceptives were not used before, but a decreased rate after previous oral contraceptive use (selection on relative insusceptibility). Because pregnancy has a

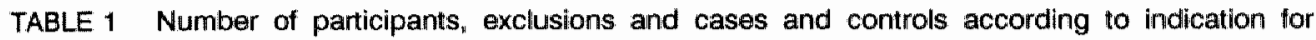
referral (acute or elective)

\begin{tabular}{|c|c|c|c|c|}
\hline Participants & $\begin{array}{c}\text { Cholecystectomy } \\
\text { patients }\end{array}$ & $\begin{array}{l}\text { Radiodiagnosis } \\
\text { patients }\end{array}$ & $\begin{array}{c}\text { General population } \\
\text { sample }\end{array}$ & Total \\
\hline Candidates & 154 & 201 & 488 & \\
\hline Non-respondents & $24(16 \%)$ & $25(12 \%)$ & $137(28 \%)$ & \\
\hline Excluded & 19 & 24 & 46 & \\
\hline Non-caucasians & & 1 & 2 & \\
\hline History of gallstiones & $16^{*}$ & $12^{* *}$ & $44 t$ & \\
\hline Inconclusive gallstone status & 34 & 115 & & \\
\hline Subjects for analysis & 111 & 152 & 305 & \\
\hline Acute cases & 85 & 15 & & 100 \\
\hline Population controls & & & 305 & 305 \\
\hline Elective cases & 26 & 15 & & 41 \\
\hline Radiodiagnosis controls & & 122 & & 122 \\
\hline
\end{tabular}

- Gallstone diagnosis longer than one year boflore.

+ Histony of gallstones (6 woment, biliery colic (16 women) or cholecystectomy (22 wamen).

\# No gallstones found during cholecystectomy despite of a positive ultrasound examination.

S. Utrasound or X-iray exam unconclusive becewse of technical reasons (3 womem), or bacause of a negative oxam in pationte with biliary collo suggesting gellstones had passed (8 women). 
similar effect on biliary cholesterol saturation as oral contraceptive use, a previous pregnancy may cause selection on susceptibility for the effect of oral contraceptive use (correlated susceptibility). Therefore, the effect of oral contraceptive use $0-5$ years before the diagnosis was assessed in separate analyses for women without and with previous oral contraceptive use and/or pregnancies (i.e. 6+ years before diagnosis). Statistical significance of the differences in these subgroups was tested by assessing interaction in an analysis on all subjects.

\section{RESULTS}

Table 1 presents the numbers of cases and controls. In all, there were 100 acute cases and 305 general population controls, and 41 elective cases and 122 radiodiagnosis controls.

When controlling for the matching factors only, oral contraceptive use was found to be associated to a 1.6 fold increased rate of gallstone disease in the $0-5$ year risk period (table 2, model 1). In later risk periods the rates were not far from the reference rates (rate ratios near 1.0 ).

When potential confounders were controlled for (table 2 , model 2 ), the rate ratios for the $0-5$ and 6-10 year risk periods changed considerably (rate ratios 1.2 and 1.7 respectively). The factors with the largest confounding effects were alcohol use, body mass index, and age at menarche, at least when they were considered jointly. No single

TABLE 2 Risk period specific number of oral contraceptives (OC) users and non-users, and rate ratios (RR) with 90 percent confidence intervals $(90 \%-\mathrm{Cl})$ of gallstone disease

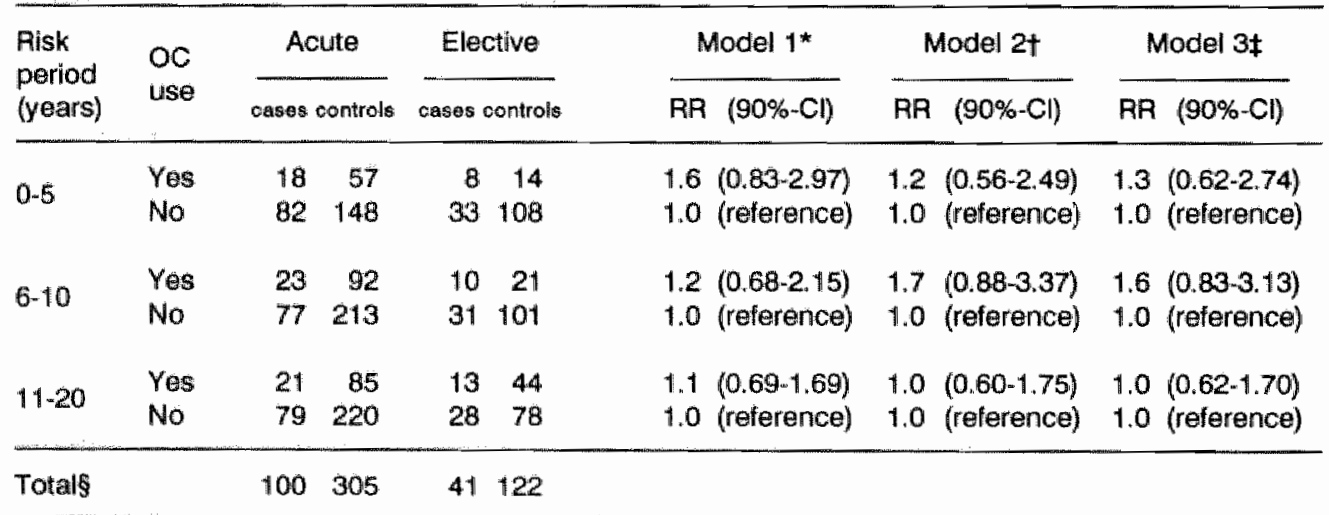

\footnotetext{
- Model 1 controlling far the matching factors only (Ange and referral indication).

1. Modial 2: controling for confounders (ege met marothe; prognancies; other sex hormone use; eatly ar late natural, artificial

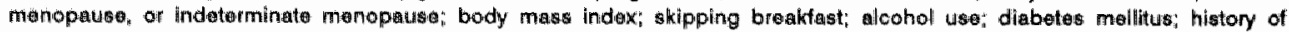
gallstones in parents).

* Models 3: Same as Model 2, but omitting bodly mass index after ar during the risk period of interest fo-5 years: comtrolling for BMII 5,10 and 15 years before diagnosis; 6-10 years: controlling for BMI 10 and 15 years before diagnosis: $111-20$ : no controll tor BMA).

- Total for each rist period.
} 
confounder accounted for a large part of the difference between the results of model 1 and 2 on its own. The results hardly changed when control for body mass index after the start of each risk period was omitted (table 2 , models 3 ).

Table 3 shows the results for oral contraceptive use 0-5 years before diagnosis (recent oral contraceptive use), depending on previous oral contraceptive use and previous pregnancy. The results suggest that the effect of oral contraceptive use is smaller after previous pregnancy (rate ratio 1.5) than if no pregnancy had occurred before (rate ratios 3.5 and 5.4 with and without previous oral contraceptive use, respectively). No dependency on previous oral contraceptive use was found. It was not possible to control for many potential confounders in this analysis, because the numbers of subjects in the subgroups were small.

TABLE 3 Numbers of oral contraceptive (OC) users and non-users 0-5 years before diagnosis (recent $O C$ use) according to previous $O C$ use and pregnancy, and rate ratios of gallstone disease for recent $\mathrm{OC}$ use (RF) with 90 percent confidence intervals $(90 \%-\mathrm{Cl})$

\begin{tabular}{|c|c|c|c|c|c|c|}
\hline \multirow{2}{*}{$\begin{array}{l}\text { Previous } \\
\text { oc use or } \\
\text { pregnancy }\end{array}$} & \multirow{2}{*}{$\begin{array}{l}\text { Plecent } \\
\text { OC use }\end{array}$} & \multicolumn{2}{|c|}{ Acute } & \multicolumn{2}{|c|}{ Elective } & \multirow[b]{2}{*}{ RA $(90 \% \mathrm{Cl})$} \\
\hline & & cases & controls & case & ontrols & \\
\hline \multirow{2}{*}{ None } & Yes & 4 & 4 & 2 & 4 & $3.5(0.64-19.8)$ \\
\hline & No & 15 & 33 & 3 & 13 & 1.0 (reference) \\
\hline \multirow{2}{*}{ Only OC use } & Yes & 7 & 25 & 3 & 7 & $5.4(0.67-44.3)$ \\
\hline & No & 1 & 13 & 1 & 2 & 1.0 (reference) \\
\hline \multirow{2}{*}{ Only pregnancy } & Yes & 0 & 3 & 0 & 1 & * \\
\hline & No & 51 & 134 & 20 & 51 & \\
\hline \multirow{2}{*}{ Both } & Yes & 7 & 25 & 3 & 2 & $1.5(0.59-3.99)$ \\
\hline & No & 15 & 68 & 9 & 42 & 1.0 (reference) \\
\hline Total & & 100 & 305 & 41 & 122 & \\
\hline
\end{tabular}

Too little information for arrabysis.

\section{DISCUSSION}

None of the earlier studies recently reviewed' were expressly designed to study the transiency of the effect of oral contraceptive use on the occurrence of gallbladder disease. Well-designed studies of the prevalence of gallstones found by screening have given estimates of the prevalence ratio for oral contraceptive use ranging from 1.3 to $1.4^{6-11}$. Many of these gallstones did not cause symptoms. Other studies addressed the effect of oral contraceptive use on the rate (incidence density) of symptomatic gallstone disease. The best designed studies showed varying results, with rate ratios from 0.7 to $1.6^{3.1215}$. The variation may at least partly be due to different representation of risk periods among the 
studies. One study showed a decreased rate of gallstone disease (rate ratio 0.7 ), explained by its authors as due to selection on relative insusceptibility ${ }^{3 s}$.

The result of the present study without control of confounding is consistent with a declining effect of oral contraceptive use in the course of time after any moment of oral contraceptive use. We did not observe modification of the effect by previous oral contraceptive use in the order of magnitude that would be consistent with the previously suggested selection on susceptibility.

In our study we paid much attention to confounding by other determinants of gallstone disedse. There appeared to be a substantial confounding effect, that could not be attributed to a single confounder. Many earlier studies controlled only for a limited set of confounders (mostly age and pregnancies), and all studies failed to specify risk periods for the confounders when necessary given the type of study'. Previously, we have pointed out that neglecting of risk periods may lead to insufficient control of confounding ${ }^{2}$. If confounding appears to be present in a study, the question remains to what extent residual confounding is present, because control of confounding in the analysis is bound to be incomplete. It may help to look for the direction of the confounding effect. Unfortunately, this was not unequivocal in our study, as the rate ratio for the $0-5$ year risk period decreased when confounders were controlled for, whereas the rate ratio for the 6-10 year risk period increased. The substantial confounding effect found in our study suggests that earlier studies may have considerably been biased as well.

The present study did not address a dose-effect relation between the risk of gallstone disease and the estrogen or progestogen dose. Two studies recently reviewed ${ }^{2}$ assessed a dose-effect relation with estrogen potency, and confirmed such a relation ${ }^{3.16}$. This is an important observation, because this dose-effect relation does not likely result from confounding by other variables. Variables that are associated to oral contraceptive use are probably not associated to dose. Obesity may be an exception, since obese women are sometimes given higher doses of oral contraceptives. Body mass index was controlled for in one of the two studies ${ }^{16}$.

Neither of these two studies could exclude an effect of modern low dose oral contraceptives. To be able to do so, any further study of oral contraceptive use should focus on the occurrence of gallstone disease during the first decade after the start of lowdose oral contraceptive use. Such a study should make sure to include sufficient numbers of women who start low-dose oral contraceptive use for the first time (in cohort studies) or who have started low-dose oral contraceptive use recently (in case-control studies). Special attention should be paid to risk-period specific confounding by alcohol use, age at menarche and body mass, since these variables were found to be important confounders in our study. As an alternative to epidemiologic studies, we suggest that safety of oral contraceptives with respect to symptomatic gallbladder disease should be based on experimental pathophysiologic research in humans, which should include effects on biliary cholesterol saturation and gallbladder function. 


\section{REFERENCES}

1. Thijs C, Knipschild P. Do oral contraceptives cause gallbladder disease? A review of epidemiologic studies. (subrnitted)

2. Thijs C, Knipschild P, Leffers P. Pregnancy and gallstone disease. The importance of specification of risk periods in etiologic research. Am J Epidemiol 1991;134:186-95.

3. Royal College of General Practioners" Oral Contraception Study. Oral contraceptives and gallbladder disease. Lancet 1982;ii:957-9.

4. Miettinen OS. Theoretical epidemiology. Principles of occurrence reseatch in medicine. New York: Wiley, 1985.

5. Bennion L, Grundy SM. Risk factors for the development of cholelithiasis in man (second of two parts). N Engl J Med 1978;299:1221-7.

6. Rome Group for the Epidemiology and Prevention of Cholelithiasis (GREPCO). Prevalence of gallstone disease in an Italian adult female population. Am J Epidemiol 1984;119:796-805.

7. Sorf $M$, Krisio V, Sulek $P$, et al. Do oral contraceptives increase the risk of development of cholelithiasis? Ceskoslovenska Gynackologie 1987;52:434-7.

8. Maringhini A, Marcenó MP, Lanzarone F, et al. Sludge and stones in gallbladder after pregnancy. Prevalence and risk factors. J Hepatol 1987;5:218-23.

9. Jorgensen T. Gall stones in a Danish population: fertility period, pregnancies, and exogenous flemale sex hormones. Gut 1988;29:433-9.

10. Maurer KR, Ewerhart JE, Knowler WC, Shawker TH, Roth HP. Risk factors for gallstone disease in the Hispanic populations of the United States. Am J Epidemiol 1990;131:836-44.

11. Pannwitz $\mathrm{H}$, Nurnberg D, Berndt $\mathrm{H}$. Zur Epidemiologie von Gallenblasensteinen (GS) bei jungen Frauen. Leber Magen Darm 1990;20:198-92,194.

12. Royal College of General Practioners. Orat Contraceptives and Health. London: Pitman Medical, 1974:57-9.

13. Vessey $M$, Doll $R$, Peto $R$, Johnson B, Wiggins P. A long-term follow-up study of women using different methods of contraception - An interim report. J Biosoc Sci 1976;8:373-427.

14. Layde PM, Vessey MP. Yeates D. Risk factors for gall-bladder disease: a cohort study of young women attending family planning clinics. J Epidemiol Comm Health 1982;36:274-8.

15. Scragg RKR, McMichacl AJ, Seamark RF, Oral contraceptives, pregnancy, and endogenous oestrogen in gall stone disease -a case-control study. Brit Med $\mathrm{J}$ 1984;288:1795-9.

16. Strom BL, Tamragouri RN, Morse ML, Lazar EL, West SL, Stolley PD, Jones JK. Oral contraceptives and other risk factors for gallbladder disease. Clin Pharmacol Ther 1986;39:335-41. 



\title{
7 \\ VETZUCHT EN LIJNEN
}

\author{
Wordt galsteenziekte veroorzaakt door vetzucht \\ of door lijnen?
}

Eerder onderzoek heeft aannemelijk gemaakt dat snel vermageren de vorming van galstenen bevordert. Het is mogelijk dat het welbekende verband tussen vetzucht en de kans op galsteenziekte (mede) wordt veroorzaakt doordat dikke mensen vaker vermageringskuren volgen ("lijnen"). Het doel van het onderhavige onderzoek is om de effecten van vetzucht en lijnen op het optreden van galsteenziekte te ontwarren.

Dit patiënt-controle onderzoek omvatte 151 patienten met acute symptomatische galsteenziekte en 451 controlepersonen uit de algemene bevolking. De effecten van vetzucht (gemeten als Quetelet-index) en lijnen (aantal kuren, mate van gewichtsverlies) werden ontrafeld in multivariate analyses.

Zowel lijnen als Quetelet-index waren geassocieerd met het optreden van galsteenziekte. De associatie met lijnen verdween grotendeels indien voor Quetelet-index werd gecontroleerd (incidentiedichtheidsratio 1,4; $95 \%$ betrouwbaarheidsinterval 0,8-2,4). Andersom veranderde het verband met de Quetelet-index niet indien voor lijnen werd gecontroleerd.

De relatie tussen lijnen en het optreden van galsteenziekte werd verder geanalyseerd per risicoperiode (het eerste jaar, en 1-5, 6-10 en 11-15 jaar na lijnen). Er werd geen consistent risicoperiode-specifiek effect gevonden indien voor Quetelet-index werd gecontrolleerd. Een gemiddelde latentietijd van rond vijf jaar werd gevonden voor het effect van vetzucht op het optreden van acute galsteenziekte.

Het verband tussen vetzucht en galsteenziekte is geen gevolg van lijnen. Bij personen met vetzucht leidt lijnen niet tot een verhoogd risico op acute galsteenziekte op langere termijn. 


\title{
7 \\ IS GALLSTONE DISEASE CAUSED BY OBESTTY OR BY SLIMMING?
}

\author{
Carel Thij, Paul Knipswid, and Pieter Lefers

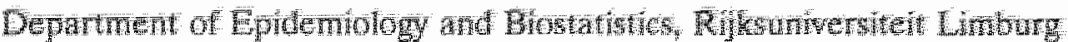 \\ the Netheriands
}

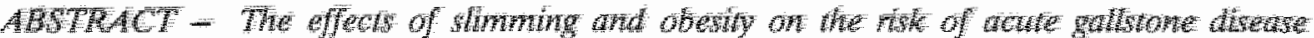

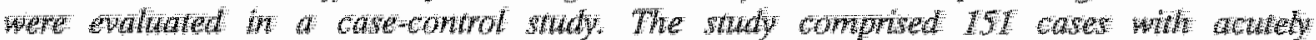

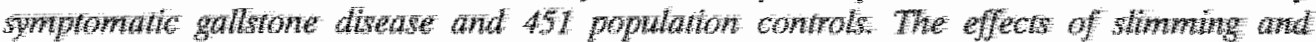

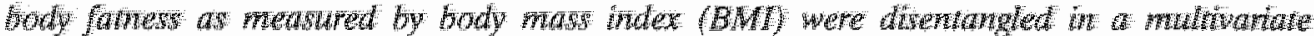

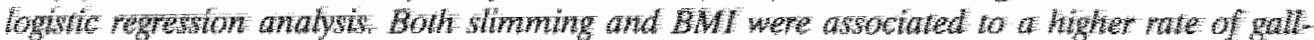

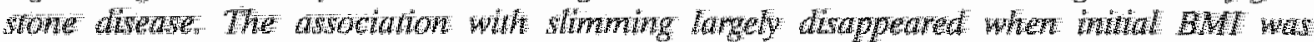

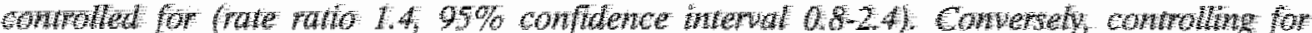

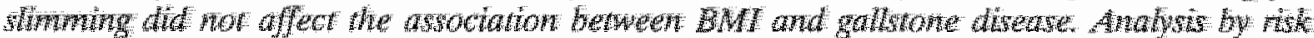

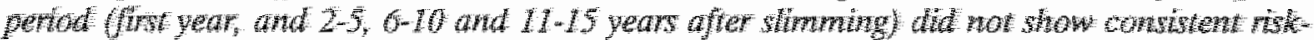
period spectic effects when initial BMI way controlled for. Tre effect of body mass an actate gathothe disease was found to have mean a latency period of wbou 5 years. It is concluded

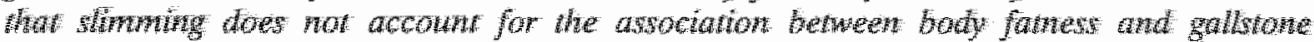
diwetwe. Wh obese persons stimming does not increase the risk of acute gallione diwease in the long nut. (A shomened version will appeat in the Americun Joumal of Epidemiology in the beginning of 1992).
\end{abstract}

\section{INTRODUCTION}

Obesity is an established risk factor for gallstones ${ }^{1-4}$. It does not automatically follow that weight reduction prevents the development of gallstone disease. In metabolic studies halt of the subjects who followed a weight-reduction diet had a transient increase of bile lithogenicity'. Rapid weight loss after gastric bypass has been reported to result in a high rate of gallstone formation and associated symptoms ${ }^{3.9}$. Therefore, it has been suggested that weight reduction might enhance the risk of gallstone disease, especially if weight loss is not maintained ${ }^{1,2}$. Consequently, the higher risk of gallstones in obesity may partly be explained by the greater instability of higher body mass.

In a case-control study we attempted to disentangle the effects of voluntary weight reduction (slimming) and body mass on the risk of acutely symptomatic gallstone disease. 


\section{METHODS}

\section{Subjects}

Gallstone cases were a series of patients with acutely symptomatic gallstone disease diagnosed in Academic Hospital Maastricht in a two year period in 1983-1985. A random sample from the general population of the catchment area of the hospital (the one and only hospital serving that region) was chosen to provide for the control group. Admission criteria for both cases and controls were age 30 to 76 for males and 20 to 76 for females.

Gallstone cases were identified at the register of admissions for cholecystectomy or the register of referral for diagnostic investigation of the gallbladder at the Department of Radiology. Patients were selected who had newly diagnosed acute gallstone disease (biliary colic of recent onset, acute cholecystitis, cholangitis, pancreatitis, or obstructive jaundice, as reported in the hospital records of the cholecystectomy patients, or in the referral forms of the radiology patients) and who had surgically or radiologically confirmed gallstones in their gallbladder. This yielded 151 cases $(51$ men and 100 women, response rate $86 \%$ ).

The control group was composed of subjects from age- and sex-stratified random samples from the municipal population registries of the town of Maastricht and one of the three surrounding villages as of 1983. Subjects with a history of symptomatic gallstone disease (radiological gallstone diagnosis, biliary colic or cholecystectomy) were excluded. The control group comprised of 451 subjects (146 men and 305 women, response rate $72 \%$ ).

\section{Measurements}

Questions about voluntary weight reduction addressed the number of slimming courses and maximal weight loss that had resulted. This was asked for the year previous to interview and the time intervals between one, 5,10 and 15 years earlier. In addition, the subjects were asked whether their weight generally remained lower after slimming or was rapidly regained. Current body weight and height was asked, and measured by the interviewer in cases of doubt. Body weight was also asked for 5,10 and 15 years before interview.

\section{Analysis}

Rate ratios for slimming and BMI were computed as odds ratios in categorical logistic regression analysis ${ }^{11}$. To obtain estimates of risk-period specific effects of slimming, the effects of slimming in each risk period were separated from each other by including all slimming variables for the risk periods in each of the regression models"

Primarily, slimming was analyzed as a dichotomous variable (yes/no). Dose-effect relationships were evaluated by using undicator variables for the number of slimming courses and the maximum amount of weight loss (as continuous variables) in nested models ${ }^{\mathrm{I1}}$. Rapid weight regain was evaluated likewise. Body mass index (BMI, weight (kg) divided by height squared $\left(\mathrm{m}^{2}\right)$ ) was categorized into 6 categories, including one representing missing data (mainly young subjects whose BMI in the past pertained to 
ages below 15). Each analysis was done without and with control for BMI at the beginning of the pertaining period ("initial $\mathrm{BMI}^{\prime}$ ).

A similar analysis was performed for the entire period from 15 years earlier up to the time of diagnosis.

The strategy of control for confounding needs some discussion. People who slim will likely be heavier at the outset than people who do not. For this reason, initial BMI should be controlled for. Controlling for BMI at the end of the risk period of interest would be inadequate if the effect of slimming is mediated by change of BMI, or even if BMI is only an indicator of some factor in the pathogenetic mechanism of gallstone formation, e.g. serum lipids ${ }^{13}$. For these reasons, each analysis was done with control for BMI at the beginning of the pertaining risk period ("initial BMI").

The same argument holds also for confounding by habits that may be part of the slimming activities by which weight reduction is achieved. Habits that are risk factors of galistone disease may differ among people who slim and people who do not slim. As far as these habits precede slimming, they can be considered to be potential confounders, which should be controlled. Such potential confounders are physical activity, not eating breakfast, and alcohol use. By contrast, change of these risk factors may be intermediate factors, which should not be controlled for. For this reason, we controlled for physical activity (sitting life-style (yes/no)), not eating breakfast ( 3 categories) and alcohol use, at the beginning of each risk period (and earlier, if needed). Alcohol use was represented by 3 categories denoting pattern of use (never/seldom; irregular; regular), and indicators of the dose (number of drinks per week) for each pattern separately.

Other confounders controlled for in all models were (number of categories in brackets): sex; age (6); interviewer (3); pregnancy (2) and oral contraceptive use (2) in four risk periods; ever use of cholesterol-lowering drugs (2) or long-term use of analgesics (2); medical diagnosis of diabetes (2); and history of gallstones in brothers (2), sisters (2), and father and mother (5).

Evaluation of interactions in the logistic regression models showed no major differences of the results for men and women. For this reason the results are shown for men and women combined.

\section{RESULTS}

\section{Ever slimming}

A considerable proportion of the participants (166 out of $602(28 \%)$ ) reported to have slimmed at any time. Slimming at any time was associated to a higher rate of gallstone disease, compared to never slimming (rate ratio $(\mathrm{RR})=2.0,95 \%$ confidence interval 1.24-3.22, table 1). However, confounding of the effect of slimming by initial body mass is most likely, since the two conditions for confounding are met: (1) the proportion of subjects who had slimmed increased with initial BMI (figure 1); and (2) the rate of gallstone disease increases with initial body mass (BMI 15 years before diagnosis, figure 2). When confounding was prevented by controlling for initial BMI in the analysis, the rate ratio for slimming decreased to $1.4(0.84-2.40)$. The other way round, the relation between gallstone disease and initiall BMI 15 years before interview was similar when slimming was controlled for or not (results not shown). 
TABLE 1 Gallstone cases and controls by slimming during the 15 years previous to interview. Rate ratio for acute gallstone disease (RR) with $95 \%$ confidence interval ( $95 \%$-C), controlling for all confounders except initial BMI (logistic regressiom analysis)

\begin{tabular}{|c|c|c|c|c|c|c|}
\hline \multirow{2}{*}{ Slimming } & \multicolumn{2}{|c|}{ Men } & \multicolumn{2}{|c|}{ Women } & \multirow{2}{*}{ RR } & \multirow{2}{*}{$(95 \%-\mathrm{Cl})$} \\
\hline & \multicolumn{2}{|c|}{ cases controls } & \multicolumn{2}{|c|}{ cases controls } & & \\
\hline yes & 16 & 27 & 41 & 82 & 2.0 & $(1.243 .22)$ \\
\hline no & 35 & 119 & 59 & 223 & 1.0 & (rofierence) \\
\hline total & 51 & 146 & 100 & 305 & & \\
\hline
\end{tabular}

$\%$ slimmers

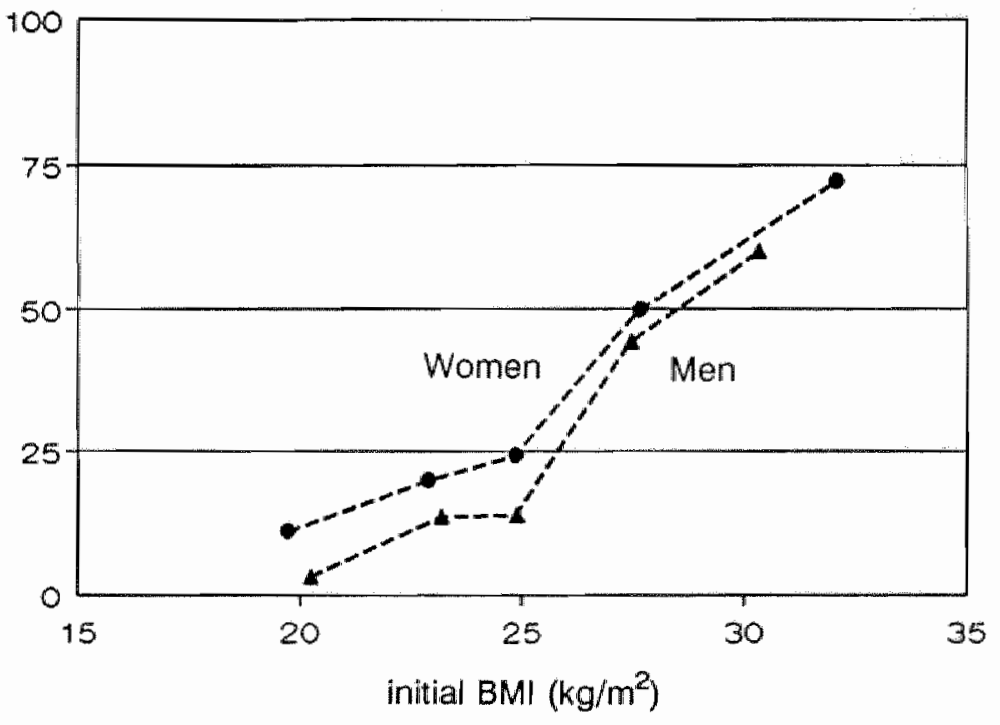

FIGUAE 1 Proportion (\%) of subjects who have slimmed at any time, according to initial body mass (BMI 15 years before interview) in the control group (146 men and 305 women). Points in the graph are set at the midpoints (means) of the BMI categories. 

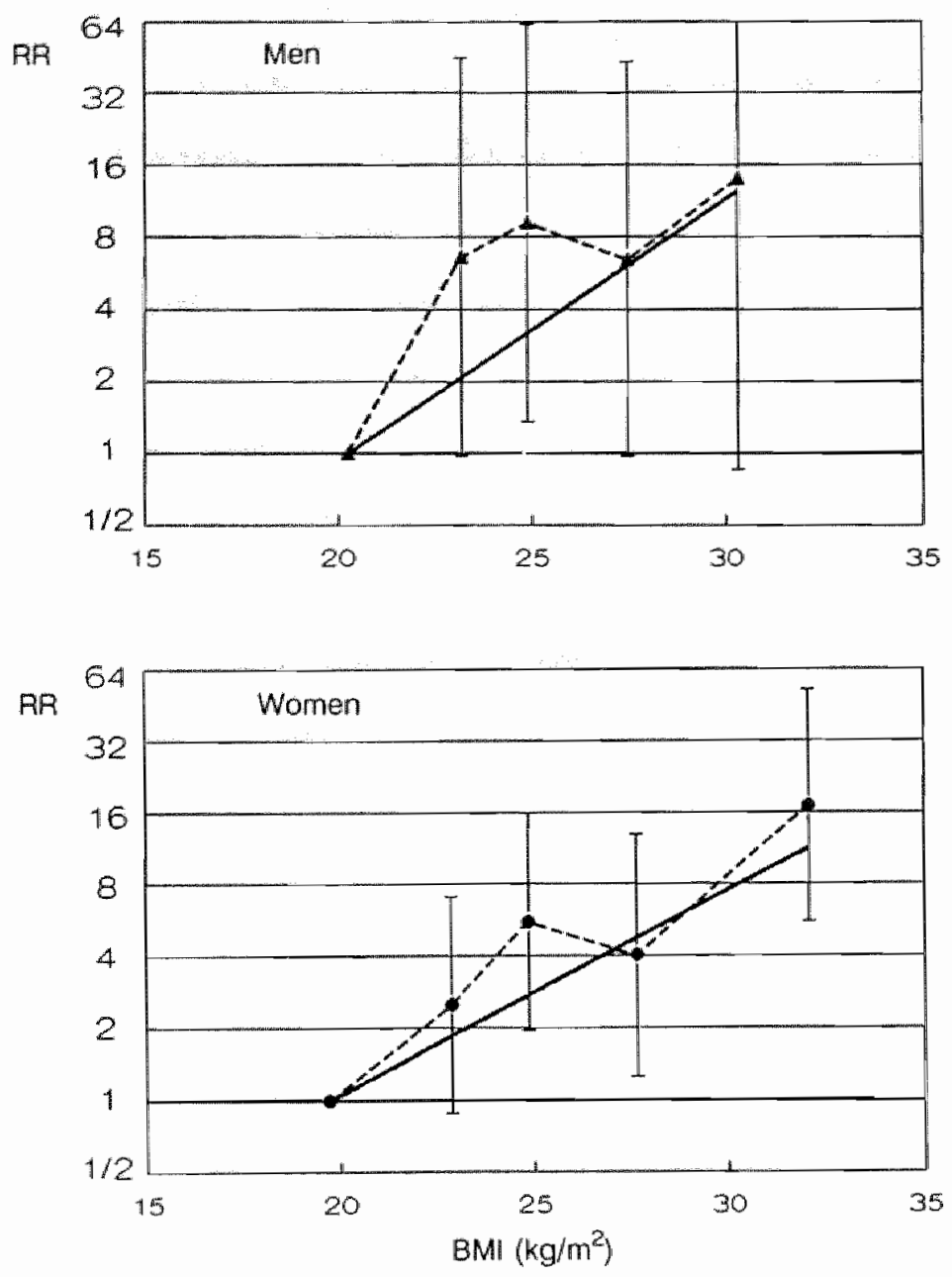

FIGURE 2 Rate of acute gallstone disease as a function of body mass index (BNAl) 15 years before interview, expressed as a ratio (RA) of the rate in the lowest BMl category. BMI categories were based on quartiles (all subjects combined), and the resulting upper category (BMI $26.3+\mathrm{kg} / \mathrm{m}^{2}$ ) was further divided into two because of its high informativeness. Categories were $\left(\mathrm{kg} / \mathrm{m}^{2}\right): 14.2-21.8 ; 21.8-24.0$; $24.0-26.3 ; 26.3-29.0 ; 29.0-44.4$. Points in the graph are set at the midpoints (means) of these categories. Broken line: Rate ratios from categorical logistic regression analysis, in men and women separately, controlling for age and interviewer (no other variables confounded the relation between $B M I$ and gallstone risk). Test of linear trend of the logarithm of the rate of gallstone disease with BMI: men $p=0.005$, women $p<0.001$ (one-sided; from logistic regression with BMIl as continuous variable). Difference of this trend between men and women: $p=0.87$ (from a logistic regression model combining the data for men and women, assessing interaction between sex and BMI as a continuous variable). Thick line: BMI as a continuous variable, controlling for age and interviewer (no other variables confounded the relation between $\mathrm{BMI}$ and gallstone risk). 
Of all subjects who had slimmed at any time, almost half (75 out of 166) had reported to have rapidly regained weight after slimming. We looked if the effect of slimming was more pronounced if it was followed by rapid weight regain in comparison to a more enduring weight loss. This was not confirmed (slimming witll rapid weight regain $R R=1.3(0.67-2.64)$; slimming with enduring weight loss $R R=1.5(0.79-2.84)$, both compared to never slimming, controlled for initial BMIy.

When the effect of slimming was considered for people with different initial BMI (table 2), the effect of slimming was suggested to be modified by initial BMI. If slimming increased the rate of gallstone disease, this seemed to be restricted to already thin people; in obese subjects, slimming even seemed to protect against gallstone disease. Figure 3 shows the results of a logistic regression model that describes this effect modification.

\section{Extreme slimming}

No dose-effect relationships were found between the risk of gallstone disease and the number of slimming courses or the maximal amount of weight ever lost. We expected an effect of slimming particularly to occur when multiple slimming courses had resulted in substantial weight loss, subsequently followed by regain of weight. Because of this, we looked at such extreme form of slimming in detail. Extreme slimming was considered to be present if the participant had engaged in slimming more than once, had lost $10 \mathrm{~kg}$ of weight or more at one (or more) of those occasions, and had rapidly regained weight. This pattern was displayed by one man only (a control), and by 23 women ( 10 cases and 13 controls; mean number of slimming courses 8.4 (range 2-49), mean amount of weight lost $17.0 \mathrm{~kg}$ (range $10-42 \mathrm{~kg}$ )). In women the rate ratio for extreme slimming was 2.4 (0.79-7.02). However, the women with this extreme slimming pattern had on average gained $7.3 \mathrm{~kg}$ of body weight in the period from 15 to 5 years before diagnosis (compared to $1.3 \mathrm{~kg}$ in the group of women who had never slimmed). When weight gain in that period was also controlled for (over and above controlling for initial BMI), the rate ratio shrunk from 2.4 to $1.2(0.39-4.00)$. Weight gain in that period was associated with a higher rate of gallstone disease ( $R R=1.5(1.20-1.84)$ per $5 \mathrm{~kg}$ gain of weight, controlling for initial BMI). This did not change when (extreme) slimming was controlled for in women.

\section{Risk period specific analysis}

The analysis was started with slimming (yes/no) in each period in one model (i.e. slimming in the year previous to diagnosis, and in the periods of 2-5, 6-10 and 11-15 years before diagnosis). Each of these periods represents a risk period, e.g. slimming in the period 6-10 years before diagnosis conveys the information on the rate of gallstone disease 6-10 years after slimming. When the interest is focused on that risk period, the inclusion of the slimming variables pertaining to the other risk periods in one and the same model warrants control of confounding by slimming in the other risk periods. Only in the 6-10 year risk period slimming was positively associated to the rate of gallstone disease ( $R R=3.5(1.52-6.31)$, table 3). After controlling for initial $B M I$, the rate ratjos of gallstone disease decreased in all risk periods. However, in the 6-10 year risk period the rate ratio remained substantial ( $R R=2.6(1.05-6.31)$ ). However, no dose-effect relation 
was found. Rather, the effect was restricted to weight loss of at most $8 \mathrm{~kg}$ (RR=12.3 $(2.85-53.2)$ ), whereas weight loss of $9 \mathrm{~kg}$ or more was not associated with the rate of gallstone disease $(\mathrm{RR}=1.2(0.40-3.60))$.

In neither of the other risk periods a consistent positive dose-effect relationship was found between the number of slimming courses and the rate of gallstone disease. Rapid weight regain after slimming was not found to be related to an important higher rate of gallstone disease once slimming was already accounted for.

TABLE 2 Gallstone cases and controls by slimming during the 15 years previous to interview, and by initial body mass (BMI 15 years before interview). Rate ratio (RA) for slimming, with $95 \%$ confidence interval $(95 \%-\mathrm{Cl})$

\begin{tabular}{|c|c|c|c|c|c|c|c|}
\hline \multirow{3}{*}{$\begin{array}{l}\text { Initial BMI } \\
\left(\mathrm{kg} / \mathrm{m}^{2}\right) \\
14.2 \cdot 21 \mathrm{8}\end{array}$} & \multirow{3}{*}{$\frac{\text { Slimming }}{\text { yes }}$} & \multicolumn{2}{|c|}{ Men } & \multicolumn{2}{|c|}{ Women } & \multirow{3}{*}{$\begin{array}{l}\text { RR } \\
5.2 \\
\end{array}$} & \multirow{3}{*}{$\frac{(95 \%-\mathrm{Cl})}{(1.33-20.5)^{*}}$} \\
\hline & & \multicolumn{2}{|c|}{ cases controls } & \multicolumn{2}{|c|}{ cases controlls } & & \\
\hline & & 0 & 1 & 5 & 11 & & \\
\hline & no & 4 & 30 & 6 & 88 & 1.0 & (reference) \\
\hline \multirow[t]{2}{*}{$21.8-24.0$} & yes & 2 & 6 & 4 & 14 & 1.0 & $(0.31-3.07)^{*}$ \\
\hline & no & 13 & 38 & 11 & 56 & 1.0 & (reference) \\
\hline \multirow[t]{2}{*}{$24.0-26.3$} & yes & 4 & 5 & 5 & 18 & 1.4 & $(0.44 .4 .41)^{\prime}$ \\
\hline & no & 10 & 31 & 14 & 28 & 1.0 & (reference) \\
\hline \multirow[t]{2}{*}{$26.3-29.0$} & yes & 8 & 12 & 9 & 15 & 1.7 & $(0.54-5,40)^{*}$ \\
\hline & no & 4 & 15 & 7 & 15 & 1.0 & (reference) \\
\hline \multirow[t]{2}{*}{$29.0-44.4$} & yes & 2 & 3 & 12 & 13 & $0: 2$ & $(0.04-1.20)^{*}$ \\
\hline & no & 4 & 2 & 12 & 5 & 1.0 & (relerence) \\
\hline \multirow[t]{2}{*}{ Unknown } & yes & - & - & 6 & 11 & & \\
\hline & no & - & 3 & 9 & 31 & & \\
\hline \multirow[t]{3}{*}{ Total } & $y \in s$ & 16 & 27 & 41 & 82 & 1.4 & $(0.84-2,40)+$ \\
\hline & no & 35 & 119 & 59 & 223 & 1.0 & (reference) \\
\hline & Total & 51 & 146 & 100 & 305 & & \\
\hline
\end{tabular}

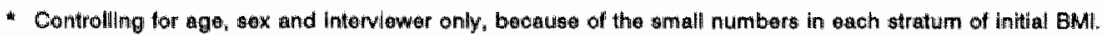

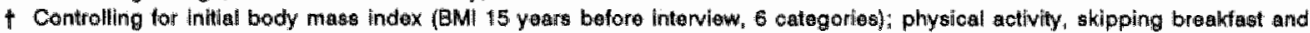

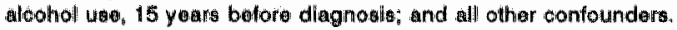

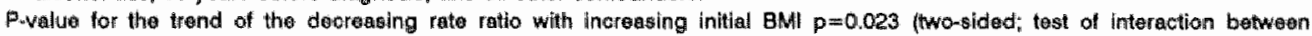

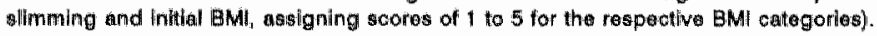




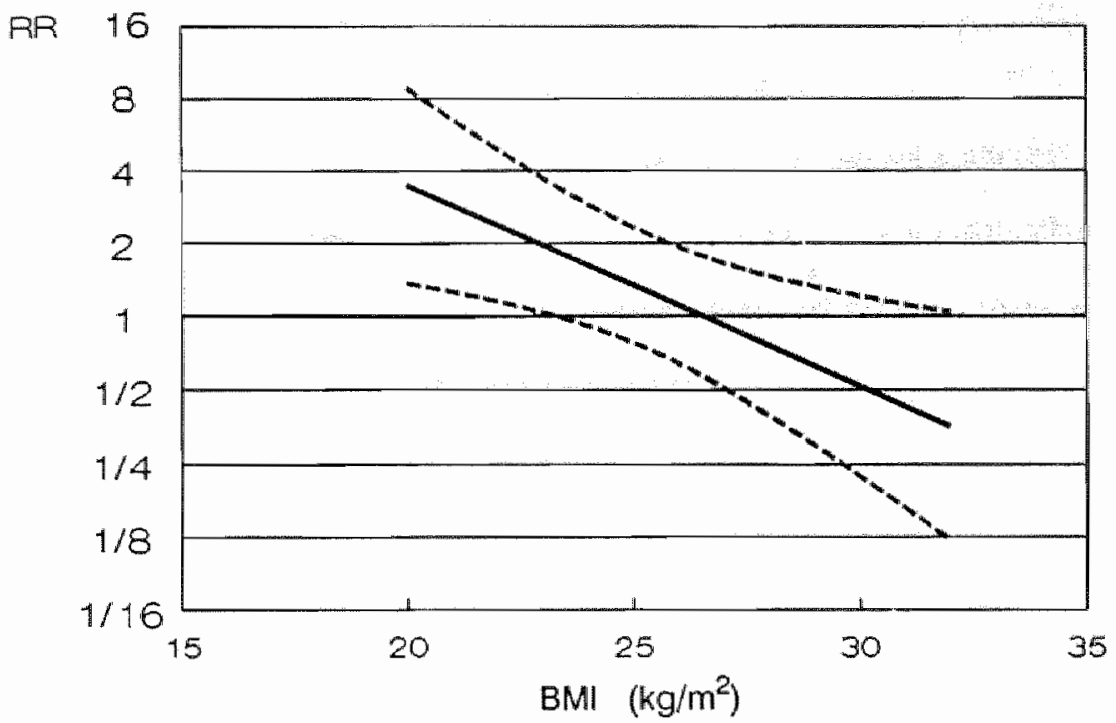

FIGURE 3 Modification of the effect of slimming (yes/no) on the rate of acute gallstone disease by initial body mass index (BMI 15 years before diagnosis), from logistic regression analysis, rate ratio (RR) with $95 \%$ confidence bands (braken line). Controlling for initial BMI (15 years before diagnosis); physical activity, not eating breakfast and alcohol use, 15 years before diagnosis; sex; age; interwiewer; pregnancy and oral contraceptive use in four risk periodls; ever use of cholesterol-lowering drugs and long-term use of analgesics; medical diagnosis of diabetes; and history of gallstones in brothers, sisters, father and mother. Test of effect-modification by BMII (assessment of interaction between slimming and $B M I$ in the logistic regression analysis) $P=0.009$.

The relationship between gallstone disease and BMI on various moments before interview is depicted in figure 4. This figure shows the effect of BMI on the occurrence of gallstone disease with various latency periods, since for BMI at one moment the effect at the other moments is controlled for (by inclusion of BMI at other moments in the same regression model). The peak of the rate of gallstone disease at 5 years before diagnosis points to a mean latency of about 5 years. The results hardly changed when slimming in the intermediate periods was controlled for (results not shown).

The association between BMI and the rate of gallstone disease in subjects with a constant body weight was of the same magnitude as that found for 5 years before interview in the total study group (figure 4). This indicates that the peak at 5 years before interview is not due to chance fluctuation, but represents a true peak of the rate of gallstone disease depending on body weight with a mean latency of about 5 years. 
Role of alcohol use

Whenever a positive association between slimming and gallstone disease is shown, the question may be raised whether the effect is mediated by a drop of alcohol intake, since alcohol abstention may be a risk factor for gallstone disease ${ }^{\text {ts }}$. For this reason, we evaluated the effect of controlling for alcohol use at the end of those risk periods that showed a substantial positive association between slimming and the rate of gallstone disease. These were the total risk period (ever slimming) and the 6-10 risk period. The positive associations found for these periods (rate ratios 1.4 and 2.6 , respectively) did not decrease when alcohol use during and at the end of these periods was controlled for (results not shown).

\section{DISCUSSION}

First of all, we want to emphasize that our study focused on a clinical problem (acutely symptomatic gallstone disease), not merely on a biological problem (formation of gallstones). By consequence, the study base from which the cases are derived is defined as

TABLE 3 Results of logistic regression analysis by risk period. Rate ratios for acute gallstone disease (RR) with $95 \%$ conlidence intervals $(95 \%-\mathrm{Cl})$. Reference categony: no slimming in each risk period (number of subjects in each category of slimming given between brackets)*

\begin{tabular}{|c|c|c|c|c|c|c|}
\hline \multirow[t]{2}{*}{ Risk period } & \multicolumn{3}{|c|}{ Not controlling for initial BMI } & \multicolumn{3}{|c|}{ Controlling for initial BMI† } \\
\hline & Slimming & $\mathrm{RP}$ & $(95 \%-\mathrm{Cl})$ & Slïmming & RR & $(95 \%-\mathrm{Cl})$ \\
\hline 11 th-15th & yes $(25)$ & 0.4 & $(0.13-1.48)$ & yes $(25)$ & 0.3 & $(0.09 \times 1.12)$ \\
\hline year & no $(577)$ & 1.0 & (reference) & no $(577)$ & 1.0 & (refierence) \\
\hline 6 th-10th & yes $(47)$ & 3.5 & $(1.52-6.31)$ & yes $(47)$ & 2.6 & $(1.05-6.31) \neq$ \\
\hline year & no $(555)$ & 1.0 & (reference) & no $(555)$ & 1.0 & (reference) \\
\hline 2nd-5th & yes $(86)$ & 1.2 & $(0.61-2.39)$ & yes $(86)$ & 0.8 & $(0.35-1.59)$ \\
\hline yoar & no $(516)$ & 1.0 & (reference) & no $(516)$ & 1.0 & (reference) \\
\hline First & yes $(80)$ & 1.2 & $(0.61-2.57)$ & yes $(80)$ & 0.9 & $(0.42-2.11)$ \\
\hline year & no $(522)$ & 1.0 & (reference) & no $(522)$ & 1.0 & (reference) \\
\hline
\end{tabular}

* All modale contanad the variables slimming tyesinol 1 year before interwlew, 1-5, 6-10, and 11-15 years betore diagnosis at the anthe the; and controlled for the following variables: physical activity, skipping breaktast and alcohol tsen, all three at the begining of ow toh risk perlod; sex, age, interviower; pregnancy and oral contraceptive use in all four tisk periods; over use of sholesterel-lowering dipgs and langterm use of analgesics; medical diagnosis of diabetes; and history of gallstones in brothers, silisterk, father and mother.

+ Control of Inittal BMI was achiovad by Inclusion of BMI 15 years botore diagnosis for tho 11 th-4 5 th year risk periad; BMI 10 and 15 yours before diagnosis for the 6th.10th yoar risk period; and BMI 5, 10 and 15 years before disgnosis for the $20-5$ th and tirst yoar risk pariods.

+ Assessment of dose-effect relationship with the maximum amount of weight last (as a continuous variable, nested to the slimming variable) showed a reversed doso-otiect rolationship $(p=0.005$ two-sided). This was translated into a model with the

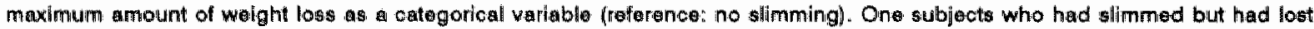

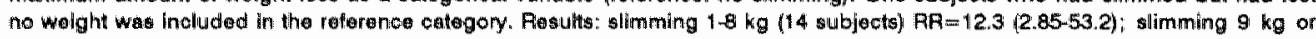
more (32 subjects) $\mathbb{R A R}=1.2(0.40-3.60)$. 
the experience over time of people who do not already have suffered from acutely symptomatic gallstone disease, regardless of whether they have gallstones or not, and who would always appear as cases in our study if they contract acutely symptomatic gallstone disease. The choice of the reference (general population control group) follows logically from this definition, since all people in the catchment region of our hospital who get acute gallstone disease will indeed appear in our hospital. This precludes bias due to selection with respect to factors related to slimming history and body fatness. The exclusion of subjects with a history of acutely symptomatic gallstone disease and the inclusion of subjects with asymptomatic gallstones, also follows from the same principle". Therefore, the presence of asymptomatic gallstones in general population controls does not lead to misclassification bias, even if the prevalence of asymptomatic gallstones is high (about $10 \%$ in men and $20 \%$ in women in our population ${ }^{15}$ ).

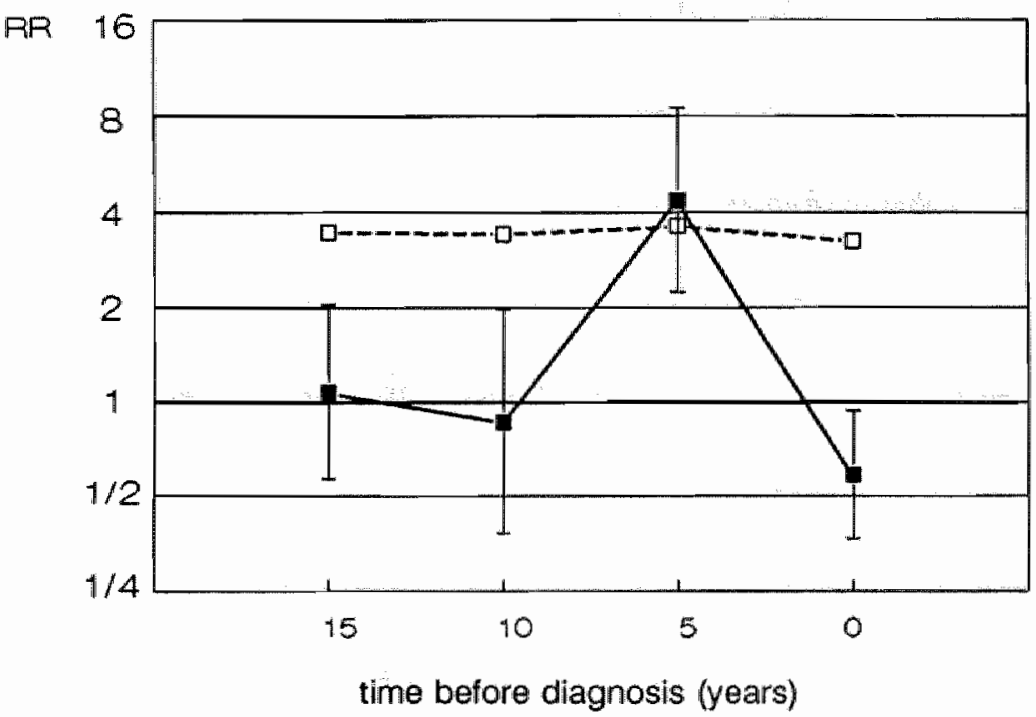

FIGURE 4 Association between body mass index (BMD) and gallstone disease, allowing for various latency periods. Rate ratios (RA) are given for a contrast of 5 units of $B M I\left(\mathrm{~kg} / \mathrm{m}^{2}\right)$, stone disease at $\mathrm{BM} \|=30 \mathrm{~kg} / \mathrm{m}^{2}$ relative to the rate at $\mathrm{BMI}=25 \mathrm{~kg} / \mathrm{m}^{2}$. Thick line: result of logistic regression analysis with $\mathrm{BMI}$ variables at different times before interview as continuous variables in one model, controlling for age, sex and interviewer (other variables did not confound the relationship); all subjects. Dotted line: analysis restricted to subjects with constant body weight (maximally $3 \mathrm{~kg}$ difference between any of the weights at interview and 5,10 and 15 years before, 35 cases, 155 contrals). (For the complementary group, subjects with variable body weight, the curve and the $95 \%$ confidence limits are similar to that for the total study group, indicated by the thick line and the vertical bars). 
The following findings distract from the idea that obese people have a higher risk of acutely symptomatic gallstone disease because they experience unsuccessful weight reduction more often than non-obese people. First, the association between slimming and gallstone disease was much weaker than the association between BMI and gallstone disease. Second, the effect of slimming always decreased substantially whenever initial body mass was controlled for, whereas the results for body mass did not change when slimming was controlled for. For as much as the relation between extreme slimming and the rate of gallstone disease in the entire 15 year risk period did not disappear fully when initial BMI was controlled for, the relation was largely accounted for by weight gain in this group of extreme slimmers. Third, in obese persons slimming seemed to protect against acute gallstone disease rather than causing it. Furthermore, within each risk period slimming was negatively related to the rate of gallstone disease, when initial body mass was controlled for. By exception, slimming was associated to a doubled rate for the 6-10 year risk period. However, all but a consistent positive dose-effect relationship with the amount of weight loss was found. Fourth, constant body weight over the last 15 years before interview was also associated to acute gallstone disease. This association was of similar magnitude as that in the entire study population, when allowing for a mean latency of about 5 years.

Various gastric and jejunoileal operations for the treatment of morbid obesity have been found to be followed by a high rate of gallstone formation and development of symptomatic gallbladder disease $e^{5.9}$. One study has shown that symptomatic gallstone disease occurred in the first two years in the majority of cases. Another study demonstrated that dieting (mean weight reduction $16.5 \mathrm{~kg}$ ) led to gallstone formation in 13 of the 51 subjects after 8 weeks, of whom 3 underwent cholecystectomy for symptomatic gallstone disease. In half of the subjects with asymptomatic gallstones, the gallstones had disappeared at six months of follow-up ${ }^{\text {t6 }}$. It has been shown experimentally that bile lithogenicity increases during weight reduction, but decreases after that to a level lower than the initial level ${ }^{17,18}$. During lifetime, gallstones develop in about one out of every six men, and two of every five women ${ }^{15}$. In obese people the incidence will be much higher. Therefore, the question remains what the net, long-term effect of dieting is in obese people ${ }^{19}$. Experimental studies so far had too short follow-up periods of sufficient numbers of subjects to answer this question, so that knowledge of the longterm risk must be based on the available non-experimental studies.

Two earlier non-experimental studies expressly assessed the effect of weight change on the risk of asymptomatic and symptomatic gallstones. In the first, the prevalence of gallstones at ultrasound screening was higher when a history of slimming was present in men, but not in women ${ }^{20}$. In the second, a prospective cohort study in women, a higher risk of symptomatic gallstone disease was found for weight gain, but not for weight loss, as computed from body weight at various moments during follow-up and in the past ${ }^{21}$. Although the latter study did not expressly address weight-reduction dieting, the results are in accordance with ours.

We found no increased rate of acutely symptomatic gallstone disease associated with slimming in obese persons when the data were considered for the entire 15 year risk period. At first glance, this suggests that slimming in obesity is not deleterious in the long run. However, a rate for a long risk period should be interpreted with caution ${ }^{12}$. 
Especially, it is important to exclude a short term increased rate of gallstone disease of sufficient magnitude to overrule a decreased rate afterwards. Our findings in any case rule out a highly increased rate during the first five years after slimming. The results for subsequent risk periods do not indicate a long term increased rate. Therefore, the risk period specific results suggest that slimming does not cause acutely symptomatic gallstone disease in the long run.

To conclude, the present study indicates that slimming is not deleterious to reduce the risk of acutely symptomatic gallstone disease in the long run, at least in obese people. This should not downgrade the value of efforts to prevent gallstone formation by dissolution agents during crash dieting, as such prophylaxis may further reduce the risk of symptomatic gallstone disease by their short term preventive effect ${ }^{22}$.

\section{REFERENCES}

1. Bennion LJ, Grundy SM. Risk factors for the development of choletithiasis in men (Second of two parts). N Engl J Med 1978;299:1221-7.

2. Strom BL, West SL. The epidemiology of gallstone disease. In: Collen S, Solloway RD, ed. Gallstones. Contemporary issues in gastroenterology Vol 4. New York: Churchill Livingstone, 1985:1-26.

3. Pixley F. Epidemiology. In: Bateson MC (ed). Gallstone disease and its management. Lancaster: MTP'

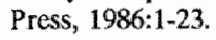

4. Scragg RKR. Aetiology of gallstones. In: Bateson MC (ed). Gallstone disease and its management. Lancaster: MTP Press, 1986:25-55.

5. Wattchow DA, Hall JC, Whiting MJ, Bradley B, lannos J, Wauts JMcK. Prevalence and treatment of gall stones after gastric bypass surgery for morbid obesity. Brit Med J 1983;286:763.

6. Deitel M, Petrov I. Incidence of symptomatic gallstones after bariatric operations. Surg Gynecol Obstet 1987;164:549-52.

7. Knecht BH. Experience with gastric bypass for massive obesity. Am Surg 1978;44:496-504.

8. Amaral JF, Thompson WR. Gallbladder disease in the morbidly obese. Am J Surg 1985;149:551-7.

9. Yang HY, Petersen GM, Marks JW, Roth MP, Schoenfield LJ. Risk factors for gallstone formation during rapid weight loss. Gastroenterol 1990;98(Suppl):A266.

10. Atilli AF. Natural history. In: Bateson MC (ed). Gallstone disease and its management. Lancaster: MTP Press, 19865:57-70.

11. Miettinen OSM. Theoretical epidemiology. Principles of occurrence research in medicine. New York: Willey, 1985.

12. Thijs $C T_{8}$ Knipschild $P G$, Leffers $P$. Pregnancy and gallstone disease. An empirical demonstration of the importance of specification of risk periods in etiologic research. Am J Epidemiol 1991;134:186-95.

13. Thijs CT, Knipschild PG, Brombacher P. Serum lipids and gallstomes. A casecontrol studly. Gastroenterology 1990;99:843;9.

14. Thijs CT, Knipschild PG, Leffers. P. Does alcohol protect against the formation of gallstones? An empirical demonstration of protopathic bias. $J$ Clin Epidemiol 1991;44:941-6.

15. Thijs C, Knipschild $P$, van Engelshoven $J$. The prevalence of gallstone disease in a Dutch population. Scand J Gastroenterol $1990 ; 25: 155-60$.

16. Liddle RA, Goldstein RB, Saxton J. Galstone formation during weight-reduction dieting. Arch Intern Med 1989;149:1750-3.

17. Bennion LJ, Grundy SM. Effects of obesity and caloric intake on biliary lipid metabolism on man. J Clin Invest 1975;56:996-1011.

18. Janowitz P, Swobodnik W, Wechsler JG, Kuhn K, Wenzel H, Wenk H, Ditschuneit $H$. Veränderungen der billiären Lithogenitä́t während einer vierwochigen Gewrichtsreduktion. Leber Magen Darm. 1989:4:190-5. 
19. Faloon WW. Hepatobiliary effects of obesity and weight-reducing surgery. Semin Liver Dis $1988 ; 8 ; 229-36$.

20. Jorgensen T. Gall stomes in a Danish population. Relation to weight, physical activity, smoking, coffee consumption, and diabetes mellitus. Gut 1989;30:528-34.

21. Maclure KM, Hayes $\mathrm{KC}$, Coldin GA, Stampfer MJ, Speizer FE, Willet WC. Weight, diet, and the risk of symptomatic gallstone disease in middle-aged women. N Eng J Med 1989;321-563-9.

22. Broomtield PH, Chopra $R$, Sheinbaum RC, Bonorris GG, Silverman A, Schoenfield LJ, Marks JW. Effects of ursodexycholic acid and aspirin on the formation of lithogenic bile and gallstones during loss of weight: N Engl J Med 198\%; 19:1567-72. 


\section{8}

\section{PEULVRUCHTEN}

De consumptie van peulvruchten en het risico op galsteenziekte - resultaten uit een patiënt-controle onderzoek

Het eten van peulvruchten verhoogt de verzadiging van gal met cholesterol, zo werd onlangs aangetoond. Daardoor is de consumptie van peulvruchten een mogelijke risicofactor voor galsteenziekte.

Toevallig voorhanden gegevens over de consumptie van peulvruchten in een patiëntcontrole onderzoek naar de etiologie van galsteenziekte werden geanalyseerd om deze hypothese te bevestigen. Er werd een omgekeerde relatie gevonden tussen de inname van peulvruchten (inclusief boontjes) en het optreden van galsteenziekte: bij het 1-7 maal per maand eten van peulvruchten was de incidentiedichtheidsratio 0,5 ( $95 \%$ betrouwbaarheidsinterval $0,28-0,88)$, bij 8 maal of vaker $0,4(0,24-0,87)$ (beide ten opzichte van minder dan 1 maal per maand gebruik van peulvruchten). Dit kon niet worden verklaard uit een verminderde consumptie van peulvruchten onder invloed van klachten die verband houden met galsteenziekte.

Wellicht bevatten peulvruchten bepaalde bestanddelen die een tegengesteld effect hebben op de vorming van galstenen. 


\title{
LEGUME INTAKE AND GALLSTONE RISK - RESULTS FROM A CASE-CONTROL STUDY
}

\author{
Carel Thijs and Paul Knipschild \\ Department of Epidemiology and Health Care Research \\ Rijksuniversiteit Limburg, The Netherlands
}

ABSTRACT - As legume intake was recently shown to increase biliary cholesterol saturation, it may be a risk factor for gallstone disease. Daia from a case-control study in the Netherlands were analyzed to confirm this hypothesis. A negative association was found between legume intake (including green beans) and gallstone risk. This appeared not to be explained by diminished legume intake in gallstone cases under the influence of gastrointestinal symptoms. We hypothesize that components from legume pulses (seed) and pods may have opposite effects on the risk of gallstone development. (Int I Epidemiol $1990 ; 19: 660-3)$

\section{INTRODUCTION}

Recentlly several older epidemiological studies on dietary risk factors of gallstone disease have been reviewed ${ }^{1,2}$ and new studies have been published ${ }^{3,4}$. None of these has addressed legume consumption as a risk factor and none of the prevailing etiologic hypotheses have assigned a role to legumes. Recently, however, the influence of legume intake on biliary lipids and cholesterol saturation was experimentally demonstrated in young Chilean men's. It was hypothesized that the effect could be due to saponins in legumes, because these substances are known to affect lipoprotein metabolism.

In a retrospective case-control study on lifestyle risk factors for gallstone disease we happened to have included questions on legume intake for a reason unrelated to the study of gallstone risk. In addition, consumption of spinach which has also a high saponin content, was determined. This enabled us to examine our data for the effect of legume and spinach intake on gallstone risk.

Gallstone patients may have reduced their legume intake because of gastrointestinal symptoms which they allready had before diagnosis. In retrospective case-control studies this may give rise to a spurious negative association between legume intake and gallstone risk (protopathic bias). Our study was expressly designed to assess the putative influence of gallstone-related gastrointestinal symptoms on dietary intake, so that protopathic bias could be evaluated. 


\section{METHODS}

\section{Subjects}

Gallstone cases were a series of patients who visited Academic Hospital Maastricht, in a two-year period in 1983-1985. All were identified from the roster of admissions for cholecystectomy or the roster of referral for diagnostic investigation of the gallbladder at the Department of Radiology. Patients who had had their gallstones diagnosed more than one year earlier were excluded. Further admission criteria for both cases and controls were age 30 to 76 for males and 20 to 76 for females, and caucasian race.

In order to ensure comparability of cases and controls with respect to the referral process, a distinction was made between cases with a compelling indication for hospital referral ("acute' cases) and cases with less clear-cut indications (elective' cases). To guide the choice of the control groups, it was argued that residents of the catchment area of Academic Hospital Maastricht with an intact gallbladder would all be admitted to this hospital if they would present with acute symptoms. Therefore, a random sample from the general population in the catchment area was chosen as the control group for acute cases. Subjects with previous cholecystectomy were excluded from this control group. Contrary to acute cases, elective cases were considered to be selected by hospital referral. Therefore, comparability with respect to hospital referral was sought by choosing a common source for both cases and controls, namely the roster of elective referrals to the Department of Radiology for diagnostic examination of the gallbladder.

\section{Acure cases and population controls}

Criteria for an acute referral indication were a diagnosis of biliary colics (not earlier than one year before referral), acute cholecystitis, cholangitis or pancreatitis, or obstructive jaundice, as reported in the hospital records of the cholecystectomy patients, or in the referral forms of the radiology patients. The control group was composed of subjects from age- and sex-stratified random samples from the municipal population registries of the town of Maastricht and one of the three surrounding villages as of 1983 . The ratio of residents from these areas was then made proportionate to the ratio in Academic Hospital Maastricht (three-quarters residents of Maastricht, one-quarter residents of surrounding willages). Subjects reporting a history of radiological gallstone diagnosis, medical diagnosis of biliary colics or cholecystectomy were excluded from the population control group.

\section{Elective cases and elecive controls}

Elective cases were patients registered on the radiology roster who showed gallstones at ultrasonographic and/or X-ray examination, but did not meet the criteria for acute referral indication. Elective controls were a sample of patients from the radiology roster in whom no gallstones were found at the examination, excluding subjects meeting the criteria for acute referral indication. Sampling was conducted by recruiting candidates on two or three pre-determined weekdays per week. 


\section{Questionnaive}

All participants were interviewed about putative life-style risk factors and gastrointestinal symptoms, and some other items unrelated to the study of gallstone disease. This included the question: In the past month, on how many days did you eat: -beans and legumes; -spinach?".

Questions about gastrointestinal symptoms included questions about; history of biliary colics (yes/no) and the following 'dyspeptic' symptoms: gastric pain, bloated feeling in the gastric region, pyrosis, nausea, vomiting, and belching. Two aspects of dyspeptic symptoms were noted: severity (severe/mild) and frequency (seldom or never/monthly/ weekly/(almost) daily). An index of 'dyspepsia' was constituted from these dyspeptic symptoms: 'much' (at least one symptom weekly or daily severe), 'little' (at least one of the symptoms monthly severe or weekly mild) and 'none' (seldom or never any of the symptoms).

\section{Analysis}

Relative risks of gallstone disease for categories of legume and spinach intake were estimated by odds ratios from contingency table analysis, using the Cochran-MantelHaenszel method to control for age, sex and referral indication. Ninety-five per cent confidence limits were computed using the test-based method". Relative risk as a function of dietary intake was studied by logistic regression analysis ${ }^{8}$ controlling for age, sex and referral indication. Dissimilarity of the results for males and females or acute and elective cases was tested by assessment of interactions in the logistic regression analysis. Since the results agreed well with those of the contingency table analysis, and no differences between males and females or acute and elective gallstone disease were found, we only present the results of the contingency table analysis.

Protopathic bias was evaluated as follows. If gallstone cases had diminished legume intake because of their disease, this would have been the result of gastrointestinal symptoms. The cases and controls differed with respect to the presence of colics and dyspeptic symptoms. If colics had led to lower legume or spinach intake, then subjects with colics would be found to have reported less legume or spinach intake than subjects without colics. The same holds for dyspepsia. This was checked by comparing frequency of intake between subjects with and without such symptoms (controlling for age, sex and referral indication, separately for cases and controls).

\section{RESULTS}

Table 1 describes the study subjects. In all, there were 204 gallstone cases ( 66 men and 138 women) and 615 control subjects ( 188 men and 427 women).

Table 2 gives the relative risks of gallstone disease associated with the reported intake of legumes and spinach. Regular intake of legumes versus eating legumes less than once a month appeared to be associated with only half the risk of gallstones. Spinach intake showed no association with gallstone risk. 
TABLE Numbers of participants, non-responders, subjects excluded; and cases and controls according to referral indication

\begin{tabular}{|c|c|c|}
\hline & $\begin{array}{l}\text { Hospital } \\
\text { patients }\end{array}$ & $\begin{array}{l}\text { Population } \\
\text { sample }\end{array}$ \\
\hline Candidates & 490 & 702 \\
\hline $\begin{array}{l}\text { Non-responders (non-response rate) } \\
\text { Excluded }\end{array}$ & $\begin{array}{l}68 \\
54 *\end{array}$ & $\frac{196}{55+}(28 \%)$ \\
\hline Study subjects & 368 & 45.11 \\
\hline $\begin{array}{l}\text { Acute cases } \\
\text { Population controls }\end{array}$ & 149 & 451 \\
\hline $\begin{array}{l}\text { Elective cases } \\
\text { Elective controls }\end{array}$ & $\begin{array}{r}55 \\
164\end{array}$ & \\
\hline
\end{tabular}

* Ome non-caucasian, 30 patients who had their galistones diagnosed more then one year belore interview, 20 patlents in whom gallstome status could not bo established with cartainty (three cholecysteterny patients in whom no gallitones were found during operation, five rediology patients whose ultrasound and (or) oral cholecystography axamination ware linconcilusive, and 12 adiology patients with recent biliary collcs but a negative exam, wiggesting gellstones had pasised) and three subjects with missing data for legume intake;

† Five noncaucasian, and 50 participanils with a history of diagnosed gallstones, biliany colics or oholecystestemy.

TABLE 2 Relative risks of gallstone disease associated with categories of legume and spinach intake, controlling for age, sex and referral indication, with $95 \%$ confidence intervals $(95 \% \mathrm{Cl})$

\begin{tabular}{|c|c|c|c|c|}
\hline & $\begin{array}{c}\text { Cases } \\
\text { No. }\end{array}$ & $\begin{array}{c}\text { Contrals } \\
\text { No. }\end{array}$ & $\begin{array}{l}\text { Relative } \\
\text { risk }\end{array}$ & $(95 \% \mathrm{Cl})$ \\
\hline \multicolumn{5}{|c|}{ Legumes (days per month) } \\
\hline$<1$ & 26 & 37 & 1.0 & (reference) \\
\hline $1-7$ & 133 & 418 & 0.5 & $(0.28-0.88)$ \\
\hline $8+$ & 45 & 160 & 0.4 & $(0.23-0.87)$ \\
\hline Total & 204 & 615 & & \\
\hline \multicolumn{5}{|c|}{ Spinach (days per month) } \\
\hline$<1$ & 76 & 238 & 1.0 & (reference) \\
\hline $1-3$ & 76 & 248 & 0.9 & $(0.56-1.53)$ \\
\hline $4+$ & 52 & 129 & 1.2 & $(0.72-1.93)$ \\
\hline Total & 204 & 615 & & \\
\hline
\end{tabular}


About two-thirds of the cases had reported colics (table 3). Dyspepsia was more prevalent among cases than controls. Gallstone cases who had reported colics did not eat legumes less frequently than cases without colics. By contrast, spinach was eaten less frequently by cases with collics than by cases without colics (19\% less, mean 1.6 versus 1.9 days a month). Dyspepsia was not associated to frequency of legume or spinach intake in any systematic way.

TABLE 3 Vegetable intake (mean number of days a month) in groups of cases and controls with varying symptoms (No. $=$ number of subjects)

\begin{tabular}{llllll}
\hline & \multicolumn{2}{c}{ Symptoms } & No. & Legumes & Spinach \\
\hline Cases & colics & yes & 139 & 4.3 & 1.6 \\
& & no & 65 & 4.4 & 1.9 \\
& \multirow{4}{*}{ dyspepsia } & much & 125 & 4.4 & 1.7 \\
& & 34 & 4.0 & 1.3 \\
& & nittle & 45 & 4.2 & 1.9 \\
Controls & dyspepsia & much & 180 & 5.2 & 1.5 \\
& & littie & 342 & 4.8 & 1.6 \\
& & none & 5.0 & 1.6 \\
\hline
\end{tabular}

None of the differences or trende reached the alpha $=0.1$ level of significance.

\section{DISCUSSION}

In contradiction to our hypothesis, legume intake was found to be negatively associated with gallstone risk. Spinach intake was not associated with gallstone risk.

Legume intake was unrelated to gastrointestinal symptoms. Therefore, it is unlikely that the observed negative association of legume intake on gallstone risk is due to diminished legume intake by gallstone cases as a consequence of symptoms (protopathic bias). By contrast, spinach intake was lower in cases with collics than in cases without colics. This may have led to underestimation of the effect of spinach intake on gallstone risk.

If in reality saponin intake increases the risk of gallstones, the absence of a positive effect of legumes in this study can be explained in several ways. First, legume intake in the Netherlands is much lower than in the experimental diet of the Chilean study $(120 \mathrm{~g}$ daily). Mean legume portion size in the Netherlands is $172 \mathrm{~g}$ (unpublished data from a food-frequency survey in the Netherlands). If this portion size is applied to our categories of legume intake, legume intake would average $22 \mathrm{~g}$ per day in the $1-7$ days/month category, and $52 \mathrm{~g}$ per day in the $8+$ days/month category. If legumes are not the major contributor to saponin intake in our study population, any separate effect of legume intake on gallstone risk could be missed easily. This is even more likely if people who do not eat legumes eat other saponin-rich foods instead. 
Second, legume intake in this study was only measured by proxy. Soya products are generally not recognized as legume by most people, and will therefore not have been reported. However, intake of soya products is low in the Netherlands. The question on frequency of legume intake included intake of green beans. Legume consumption (including green beans) was more frequent in summer months (May-September) than in winter months (October-April) in our study subjects, which is the reverse of the pattern found in the survey in the Netherlands. Legumes which are typically eaten in summer months (especially green beans) may have a different effect on gallstone risk than legume seeds. This may be due to an opposite effect of components from pulses (seeds of leguminous plants, possibly saponins) and components from pods (eg, vegetable fibre). However, studies on the effect of vegetable fibre on gallstone risk or biliary cholesterol saturation have not consistently shown a protective effect ${ }^{2}$.

Third, we were not able to control for the confounding effect of intake of foods associated with legume intake, which themselves affect gallstone risk.

These problems stress the importance, in dietary assessment, of including all foods substantially contributing to saponin intake in further studies. Moreover, if pulses and pods have opposite effects on gallstone risk, proper distinction between intake of pulses and intake of foods from leguminous plants which mainly consist of pods is crucial.

\section{REFERENCES}

1. Low-Beer TS. Nutrition and cholesterol gallstones. Proc Nutr Soc 1985; 44:127-34.

2. Scragg RKR. Aetiology of cholesterol gallstones. In: Bateson MC ed. Gallstone disease and its management. Lancaster: MTP Press, 1986:25-55.

3. Rome group for epidemiology and prevention of cholelithiasis (GREPCO). The epidemiology of gallstone disease in Rome, Italy. Part II. Factors associated with the disease. Hepatology 1988; 8:907-13.

4. Pixley F, Mann J. Dietary factors in the aetiology of gallstones: a case control study. Gut 1988,29:15115.

5. Nervi $F$, Covarrubias $C$, Bravo $P$, et al. Influence of legume intake on biliary lipids and cholesterol saturation in young Chilean men. Gastroenterology 1989;96:825-30.

6. Miettinen OS. Theoretical Epidemiology. New York: Wiley, 1985.

7. Mietinen OS. Estimability and estimation in case-referent studies. Am J Epidcmiol 1976, 103:226-35.

8. Kleinbaum DG, Kupper LL. Applied regression analysis and other multivariate methods. North Scituate: Duxbury Press, 1978.

9. Van den Brandi PA, Goldbohm RA, Van 'I Veer P, et all. Dietary habits and the aetiology of cancer. Int J Epidemiol 1988;17:472. 


\title{
9 \\ ZONNEBADEN EN HUIDTYPE
}

\author{
Zonnebaden met een lichte huid \\ - een risicofactor voor galsteenvorming?
}

Pathobiologisch onderzoek heeft aanwijzingen gegeven dat blootstelling aan zonlicht aanleiding kan geven tot galsteenvorming bij mensen met een gevoelige huid voor zonlicht. Deze hypothese werd geëvalueerd in een patiënt-controle onderzoek bij blanke personen met buikklachten die waren verwezen voor een echografisch onderzoek van de galblaas ( 87 patiënten en 119 controlepersonen).

Bij personen die het meest gevoelig zijn voor zonlicht (Fitzpatrick huidtype I) ging een positieve houding ten aanzien van zonnebaden gepaard met een hoger galsteenrisico dan een negatieve houding. Bij personen met een ongevoelige huid (Fitzpatrick huidtype IV) werd geen verband gevonden.

Het is nog te vroeg om de eerste " $F$ " op te waarderen in de traditionele uitspraak dat galsteenpatiënten "Fair, Fat, Fertile, Forty and Female" zijn. Aangezien epidemiologisch en pathobiologisch onderzoek schaars is, dient de rol van blootstelling aan zon en/of (ultraviolet) licht eerst te worden bevestigd in nader onderzoek. 


\section{9 \\ FAIR, AND STILL A SUN LOVER:
RISK OF GALLSTONE FORMATION}

Stan Pavel", Carel Thijs ${ }^{2}$, Vaclav Potocky ${ }^{3}$, and Paul Knipschild ${ }^{2}$

"Department of Dermatology, Academic Medical Center, University of Amsterdam

2Department of Epidemiology and Biostatistics, Rijksuniversiteit Limburg

${ }^{3}$ Department of Roentgenology, Diaconessenhuis, Groningen

The Netherlands

ABSTRACT - Metabolic research has suggested that sunlight exposure may lead to the development of gallstones in people with a sun sensitive skin. This hypothesis was evaluated in a case-control study among white pavients referred for an ultrasound examination of the gallbladder (87 cases and 119 controls). In subjects with a skin sensitive to sun (Fitzpatrick skin type I) a positive attitude to sunbarhing was associated with a higher risk of gallstones than a negative atritude. In subjects wirh an insensitive skin (skin type $W$ ) no association was found. It is too early to upgrade the first " $F$ " in the traditional adage that gallstone patients are "Fair, Fat, Fertile, Forty and Female". Since both epiderniological and pathobiological evidence is scarce, the role of sun and/or (ultraviolet) light exposure and sensitivity in the etiology of gallstones should be confirmed by further research. (Accepted for publication in the Joumal of Epidemiology and Community Healih)

\section{INTRODUCTION}

Gallstone sufferers are "Fair, Fat, Fertile, Forty and Female". These famous five $F^{\prime}{ }^{3}$ have been downgraded as fallacies, "Fair" even as plain falsehood? ${ }^{2}$. Nevertheless, metabolic research has suggested some clues to link skin color to the risk of gallstone formation. One hypothesis says that activation of the pigmentary system of the skin (eg. by sun exposure) leads to increased levels of indolic melanin precursors in bile. These compounds can form a polymer network in the gallbladder that serves as a nucleus for gallstone formation. This hypothesis predicts that people with a sun sensitive skin are prone to gallstones when they endure intense exposure to sunlight. We evaluated this prediction in a case-control study.

\section{METHODS}

Subjects were recruited from patients who were referred to a local hospital in the Netherlands for an ultrasound examination of their gallbladder, age 15-65, white men 
and women with Dutch nationality. Among the 211 participants, the ultrasound exam showed 87 to have gallstones (cases). In the other 124 no gallstones could be detected in the gallbladder (controls). There were no male cases below age 40 , and therefore 5 male controls below this age were excluded from the analysis, leaving 87 cases (13 men and 74 women) and 119 controls ( 24 men and 95 women).

All subjects were interviewed by trained interviewers, using a structured questionnaire. The interview took place before the ultrasound exam, thereby blinding the study subjects and the interviewer. Questions included body weight and height, number of pregnancies, skin reactions to sunlight, and sunbathing habits. Table 1 shows how a "sun attitude" score was composed, and how the subjects were classiffed according to skin sensitivity to sunlight (conforming to Fitzpatrick's classification of skin type ${ }^{4}$ ). Typically, people with skin type II are light-skinned with red or blond hair, usually blue eyes and very often freckles. Sun attitude score was categorized by tertiles as 'negative' (score 03), 'indifferent' (score 4-6), and 'positive' (score 7-11). Skin types II and III were combined because of the small numbers of subjects in these categories.

Odds ratios of having gallstones were computed in logistic regression analysis ${ }^{5}$. Confounders controlled for were sex, age, body mass index (weight divided by height squared), and number of pregnancies. There were no statistically significant differences in the results between men and women. Therefore we present the results for men and women combined.

TABLE 1 Sun attitude score (sum of the component scores) and skin sensitivity to sunlight (skin type classification)

SUN ATTITUDE

component score

-Do you often spend your holidays

in southern countries (eg., Spain, Italy)?"

"Do you love sunbathing?"

"Do you use sun cream or sun oll when you are in the sun?"

$\begin{array}{ll}\text {-More than once a year } & 3 \\ \text {-About once a year } & 2 \\ \text {-Rarely } & 1 \\ \text {-Never } & 0\end{array}$

-No $\quad 0$

-Sometimes $\quad 3$

-Yes

5

-Always 0

Otten 1

-Riarely 2

Never 3

SKIN SENSITIVITY TO SUNLIGHT

skin type

What is your skin-reaction after long sunbathing when you do not use sun cream or sun oil?"

-Always burn
-Often burn, sometimes tan
-Often tan, sometimes burn
-Always tan




\section{RESULTS}

Sun attitude was positively associated with gallstone risk, with a statistically significant dose-effect relation (table 2 , last column). A positive sun attitude was associated with a double risk of gallstones when compared to a negative sun attitude (odds ratio 2.1). No association was found between skin type and gallstone risk when sun attitude was not taken into account (data not shown).

When the effect of sun attitude was considered for the skin types separately, the association was almost fully restricted to people with the most sensitive skin type (skin type I; table 2). In this group the odds ratio was 25.6 for a positive sun attitude compared to a negative one.

We wondered whether similar results would be obtained if we used only data on the question which we felt to be the best single indicator of sun exposure: "Do you love

TABLE 2 Number of cases and controls, and odds ratio of gallstones (RA) for sun attitude, separately for the skin types, and overall (last column), with $95 \%$ confidence intervals $(95 \% \mathrm{Cl})$

\begin{tabular}{|c|c|c|c|c|c|c|c|c|}
\hline \multirow[b]{3}{*}{ Sun attitude } & \multicolumn{8}{|c|}{ Skin type } \\
\hline & \multicolumn{2}{|r|}{1} & \multicolumn{2}{|c|}{ II and II } & \multicolumn{2}{|r|}{ IV } & \multicolumn{2}{|r|}{ All } \\
\hline & cases & controls & cases & controls & cases & controls & cases & controls \\
\hline Negative & 8 & 24 & 10 & 12 & 7 & 10 & 25 & 46 \\
\hline Indifferent & 10 & 13 & 10 & 17 & 9 & 6 & 29 & 36 \\
\hline Positive & 7 & 4 & 14 & 17 & 12 & 16 & 33 & 37 \\
\hline Totall & 25 & 41 & 34 & 46 & 28 & 32 & 87 & 119 \\
\hline Sun altitude & AR: & $(95 \% \mathrm{Cl})^{*}$ & AR & $(95 \% \mathrm{Cl})$ & RR & $(95 \% \mathrm{Cl})^{*}$ & AR $\quad($ & $(95 \% \mathrm{Cl}) \dagger$ \\
\hline Jegative & $1.0(\mathrm{r}$ & (reference) & 1.0 & (reference) & 1.0( & (reference) & $1.0(r$ & (reference) \\
\hline Indifferent & $3.4(C$ & $(0.8 \cdot 14.6)$ & 0.7 & $(0.2-2.7)$ & $2.3 i$ & $(0.5-11.0)$ & $1.5 \%$ & $(0.7-3.2)$ \\
\hline Positive & $25.6 \%$ & $(3.2-205)$ & 1.7 & $(0.5-6.2)$ & $1.8 i$ & $(0.4-7.8)^{\prime}$ & 2.11 & $(1.0-4.5)$ \\
\hline Test for trendt & & $=0.001$ & & $p=0.19$ & & $=0.21$ & & $=0.028$ \\
\hline \multicolumn{9}{|c|}{ 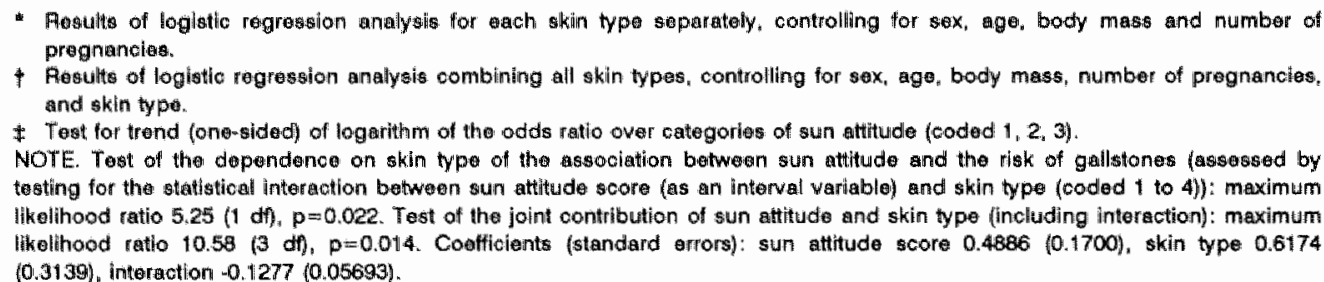 } \\
\hline
\end{tabular}


sunbathing?". The results showed the same pattern as the results on sun attitude. Among people with skin type I the odds ratios of gallstones associated with loving sunbathing were 3.2 for "sometimes" (95\% confidence interval $0.7-15.4$ ), and 8.8 for "yes" (95\% confidence interval $1.7-45.9$; compared to "no"; test for trend $p=0.003$ one-sided). In other skin types no clear association between loving sunbathing and risk of gallstones was found (data not shown).

\section{DISCUSSION}

The major weakness of this study relates to the quality of the measurements. Exposure to sunlight was only measured by proxy via "sun attitude". Sensitivity to sunlight was measured with one single subjective rating by the participant. It is questionable whether actual sun exposure and skin sensitivity can be adequately separated from each other in this way. Moreover, in patients presenting with gastrointestinal symptoms gallstones have probably formed many years before ${ }^{6}$. With our short questionnaire we could not specify sun exposure in several periods in the past to relate to a limited risk period. The resulting mismatch of time of exposure and the risk period of gallstones formation may therefore lead to underestimation of the effect, and it further hampers the separation of actual sun exposure and skin sensitivity. In view of these limitations, it is surprising that an effect of sun exposure depending on skin sensitivity could be confirmed.

Nevertheless, we think that the findings cannot easily be attributed to biases in the study. Selection bias (eg. due to earlier detection of gallstones in fair patients with vague gastrointestinal symptoms), was precluded by selection of cases and controls with the same indications for referral for ultrasound, and before the diagnosis was known. Information bias, (e.g. due to prior expectation of the interviewers who knew of the hypothesis), was avoided by blinding the patients and the interviewers with respect to the diagnosis. Main potential confounders (age, sex, pregnancy and body mass) were controlled for in the analysis. Confounding by other risk factors for gallstones that may be associated with sun attitude and that were not controlled for (eg. alcohol abstinence) is still possible. However, it is unlikely that such factors are also related to skin type. Therefore, confounding by such factors can hardly explain the dependence of the effect of sun attitude on skin type. For these reasons we believe that the result of our study could be more than an artefact.

The hypothesis engendering the present study was based on the identification of indolic melanin precursors in bile of a patient with mixed gallstones, and in the brown pigment gallstone of another patient ${ }^{3}$. The results of the present study, however, are also compatible with another mechanism: augmented photo-isomerization of unconjugated bilirubin by light exposure, enhancing the formation of (black) pigment stones. Both hypotheses link light exposure to the formation of pigment gallstones, and not necessarily to cholesterol gallstones in the first place. In the present study, we had no data on stone type. Most gallstone patients in the Netherlands have cholesterol stones. The chemical composition of pigmented centers of cholesterol gallstones has been found to be quantitatively different from that of black pigment stones, suggesting that cholesterol stones do not form on a pigment stone nidus'. However, this does not rule out that the 
small amount of non-cholesterol material in cholesterol stone centers is involved in stone nidation. Therefore, it remains possible that sun (or light) exposure is also involved in the pathogenesis of cholesterol gallstones. This may also be true for sun bed exposure.

Thus far, the evidence is sparse. Further, only a few steps in the possible mechanisms are known. It seems too early to upgrade the most intriguing of the five $F$ 's, the fair complexion of the gallstone patient. It seems that the influence of skin color in whites should not be considered without attention to sun and/or light exposure. Further epidemiological research on this topic should aim at more accurate measurement of sun exposure (and possibly light and sun beds as well), at closer timing with respect to the etiological moment of gallstone formation, and at distinguishing between pigment and cholesterol gallstones.

\section{REFERENCES}

1. Sherlock S. Diseases of the liver and biliary system (third edition). Oxford: Blackwell Scientific Publlications, 1963 , p. 641 .

2. Facts and fallacies about gall stones (Editorial), Brit Med J 1981; 283: 171.

3. Pavel S. A new possible pathogenesis of some gallstones. Med Hypotheses 1984; 14:285-92.

4. Fitzpatrick TB. Soleil et peau. J Med Esthétique 1975; 2: 33-6.

5. Kleínbaum DG, Kupper LL, Morgenstein H. Epidentiologic research. Principles and quantitatiwe methods. London: Lifetime Learning Publications, 1982.

6. Mok HX, Druffel ER, Rampone WM. Chronology of cholelithiasis, dating gallstones from atmospheric radiocarbon produced by nuclear bomb explosions. N Engl J Med 1986; 314: 1075-7.

7. Thijs $C T$, Knipschild $\mathbb{P G}_{\text {, leffers }} \mathbf{P}$. Specification of risk periods in etiologic research. An empirical demonstration with pregnancy and gallstone disease. (Submitted).

8. Ostrow JD. The etiology of pigment gallstones. Hepatology 1984; 4 (suppl): $215 \mathrm{~s}-222 \mathrm{~s}$.

9. Malet PF, Williamson CE, Trotman BW, Soloway RD. Composition of pigmented centers of cholesterol gallstones. Hepatology 1986; 6: 477-81. 


\section{PREVALENTIE VAN GALSTENEN}

\section{Een echografisch onderzoek naar de prevalentie van galstenen in Nederland}

De prevalentie van galsteenziekte in een groep ziekenhuispatiënten werd bepaald met behulp van echografisch onderzoek. Het betrof 424 mannen en 631 vrouwen, opgenomen in het Academisch Ziekenhuis Maastricht voor electieve heelkundige ingrepen die niet met galstenen samenhingen.

In de jongste leeftijdsgroep (20 tot 30 jaar) werd geen galsteenziekte gevonden. De prevalentie nam vervolgens toe met de leeftijd. In de hoogste leeftijdscatergorie (70 tot 80 jaar) werd galsteenziekte aangetroffen bij $16 \%$ van de mannen en bij $40 \%$ van de vrouwen. Van alle mannen met galsteenziekte had ruim éénderde een galblaasoperatie ondergaan; bij vrouwen was dit de helft. Met behulp van vragenlijstgegevens van een steekproef uit de algemene bevolking werden aanwijzingen verkregen dat de prevalenties in de algemene bevolking vermoedelijk enigzins lager zijn.

Een nederlandstalige versie van dit artikel verscheen in het Nederlands Tijdschrift voor Geneeskunde (1989;133:110-4) 


\title{
THE PREVALENCE OF GALLSTONE DISEASE IN A DUTCH POPULATION
}

\author{
Carel Thijs, Paul Knipschild and Jos van Engelshoven \\ Department of Epidemiology/ Health Care Research, Rijksuniversiteit Limburg, \\ and Department of Radiology, Academic Hospital Maastricht, \\ The Netherlands
}

ABSTRACT - The prevalence of gallstone disease was studied by ultrasound screening of a hospital population of 424 men and 631 women, admitted to the Academic Hospital Maastricht (The Netherlands) for elective surgery unrelated to gallstone disease. The prevalence increased with age. In the oldest age category (70 to 79 years) $16 \%$ of the men and $40 \%$ of the women had gallstone disease. The proportion of subjects with gallstone disease who had undergone cholecystectomy was $39 \%$ in men and $50 \%$ in women. The prevalence of gallstone disease in Mastrich lies on the lower side within the range of the prevalences found in other West European countries. (Scand J Gastroenterol 1990;25:155-60)

\section{INTRODUCTION}

The idea that gallstones are fairly prevalent in the Netherlands is based on autopsy studies $^{1-10}$ and screening studies ${ }^{11-19}$ in West European countries. However, accurate prevalence figures are not available in the Netherlands, as no population screening studies have been done in this country.

This article reports upon the results of ultrasound screening of a hospital population, thought to be representative of the general population of the town of Maastricht and its surrounding villages with regard to the prevalence of gallstones. The results of the present study are compared with results from other screening studies in Western Europe.

\section{SUBJECTS AND METHODS}

\section{Subjects}

The subjects were recruited in order to form reference groups in a case-control study of the aetiology of gallstone disease ${ }^{20}$ and a study of dyspepsia and gallstones ${ }^{21}$. These subjects were patients admitted to Academic Hospital Maastricht from September 1983 to July 1987 for selected elective surgical procedures not known to be related to gall- 
stones. Inclusion criteria were age 20 to 80 years, and Dutch nationality of the subject and of both parents.

Four hundred and twenty-four men and 631 women participated (response rates, $82 \%$ and $76 \%$, respectively). The operation indications of the participants were as follows: inguinal hernia, 229 men and 17 women; varicose veins, 50 and 144; heamorroids, 36 and 26 ; carpal tunnel syndrome, 38 and 186; gynaecologic, 0 and 127 ; orthopaedic 34 and $86 ;$ and ophthalmologic, 37 men and 45 . The age distribution of the participants is given in table 1 .

TABLE 1 Results of ultrasound screening of the hospital population (letters between parentheses refer to figure 1)

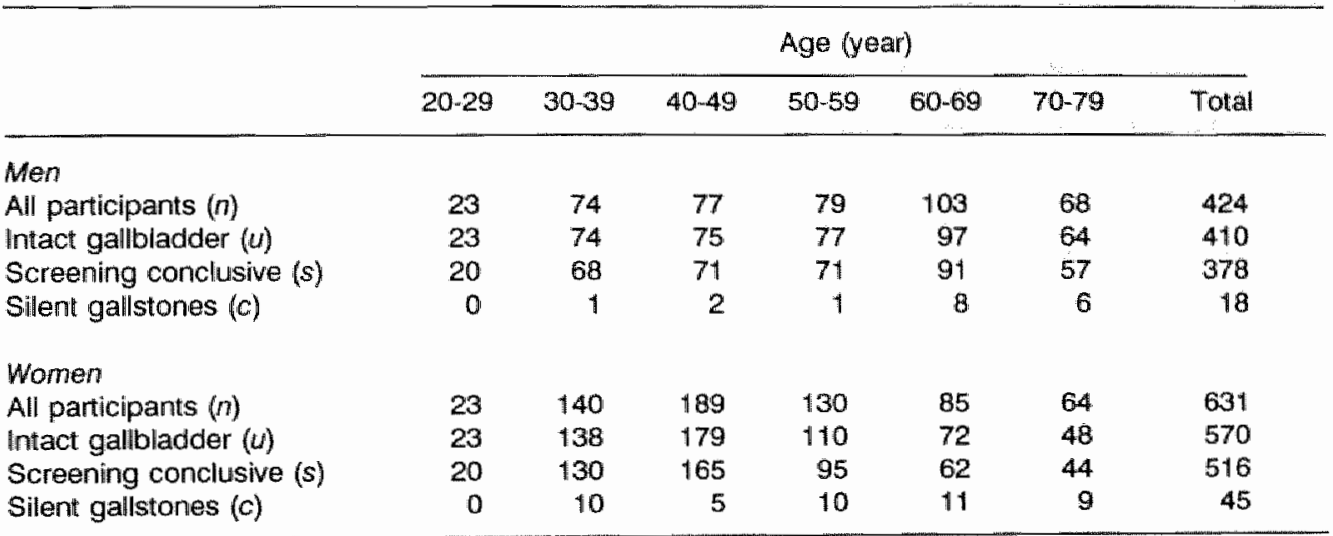

\section{Measurements}

All participants were interviewed by specially trained personnel from a commercial interviewing bureau or from our Epidemiology Department. The presence of previous gallstone diagnosis was determined with the help of questions about past radiological examinations and their results and a question about gallbladder operations.

Previous diagnoses of gallstones reported by hospital population participants were verified by checking hospital records. In doubtful cases an ultrasound examination was performed. Thirteen men and 55 women had undergone cholecystectomy, whereas one man and 6 women had a previous diagnosis of gallstones without cholecystectomy.

The gallbladder was examined by ultrasound unless a previous diagnosis of gallstones or a gallbladder operation was reported. This examination, however, was refused by 28 male and 50 female participants in spite of their informed consent. The ultrasound examination was done by a radiologist, using a mechanical sector scanner (Technicare: autosector or MCC, Pie Data: 1120) and a 3.5 or $5 \mathrm{MHz}$ transducer. The galubladder was scanned after a six-hour fast. The scans were performed in both the long and the short axis, with the patients in supine or left lateral decubitus position. Criteria for gallstone diagnosis were an echogenic structure situated within the lumen of the 
gallbladder, casting an acoustic shadow and moving with gravity or, if no gallbladder was viswalised, a sharply defined shadow behind a high level echoes in the gallbladder fossa which, in turn, might be situated just behind a small hypoechoic rim ${ }^{22.23}$. In eight subjects the ultrasound examination was inconclusive (four men and four women).

\section{Analysis}

The following life-time prevalences were computed (letters refer to figure 1 ): prevalence of (past) cholecystectomy, $a / n$; prevalence of (previously) diagnosed gallstones, $b / n$; and prevalence of silent gallstones at ultrasound screening, $c / s$.

The latter prevalence reflects the prevalence of silent gallstones in subjects with an intact gallbladder without previous gallstone diagnosis on the condition that the prevalence of gallstones in subjects who refused ultrasound screening and in subjects whose exam was inconclusive was similar to the prevalence in participants in whom ultrasound screening was conclusive. If so, the expected number of persons with silent gallstones in the total study population is $(c / s) \times u$.

If, in addition, it is assumed that gallstones were present in all cases of cholecystectomy, then the life-time prevalence of gallstone disease can be defined as the proportion of persons with cholecystectomy, or diagnosed gallstones, or silent gallstones: $(a+b+(c / s) \times u) / n$.

Ninety-five percent confidence intervals were computed by the Standard Jackknife method ${ }^{24}$.

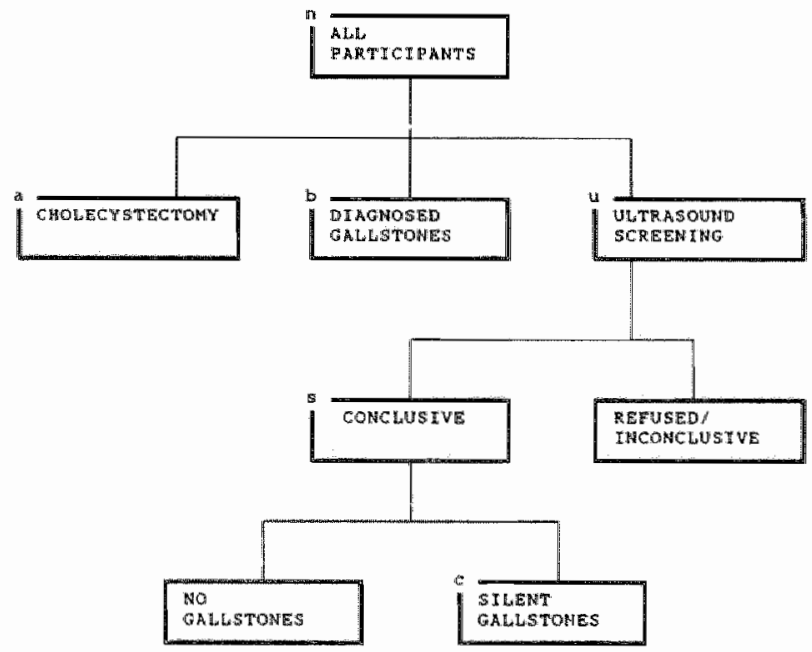

FIGURE 1 Design of the study. 


\section{Comparison with other studies}

To enable us to compare prevalence figures found in the West European studies, including the present study, an age range was selected for which most of the larger studies reported age-specific prevalence figures. Subsequently, prevalences within this age range were standardized, with 10-year age groups of equal sizes as the standard.

\section{RESULTS}

The results of ultrasound screening of the hospital population are shown in table 1. The age and sex specific prevalences of total gallstone disease and cholecystectomy are graphically presented in figure 2 , as is the prevalence of silent gallstones in subjects with an intact gallbladder.
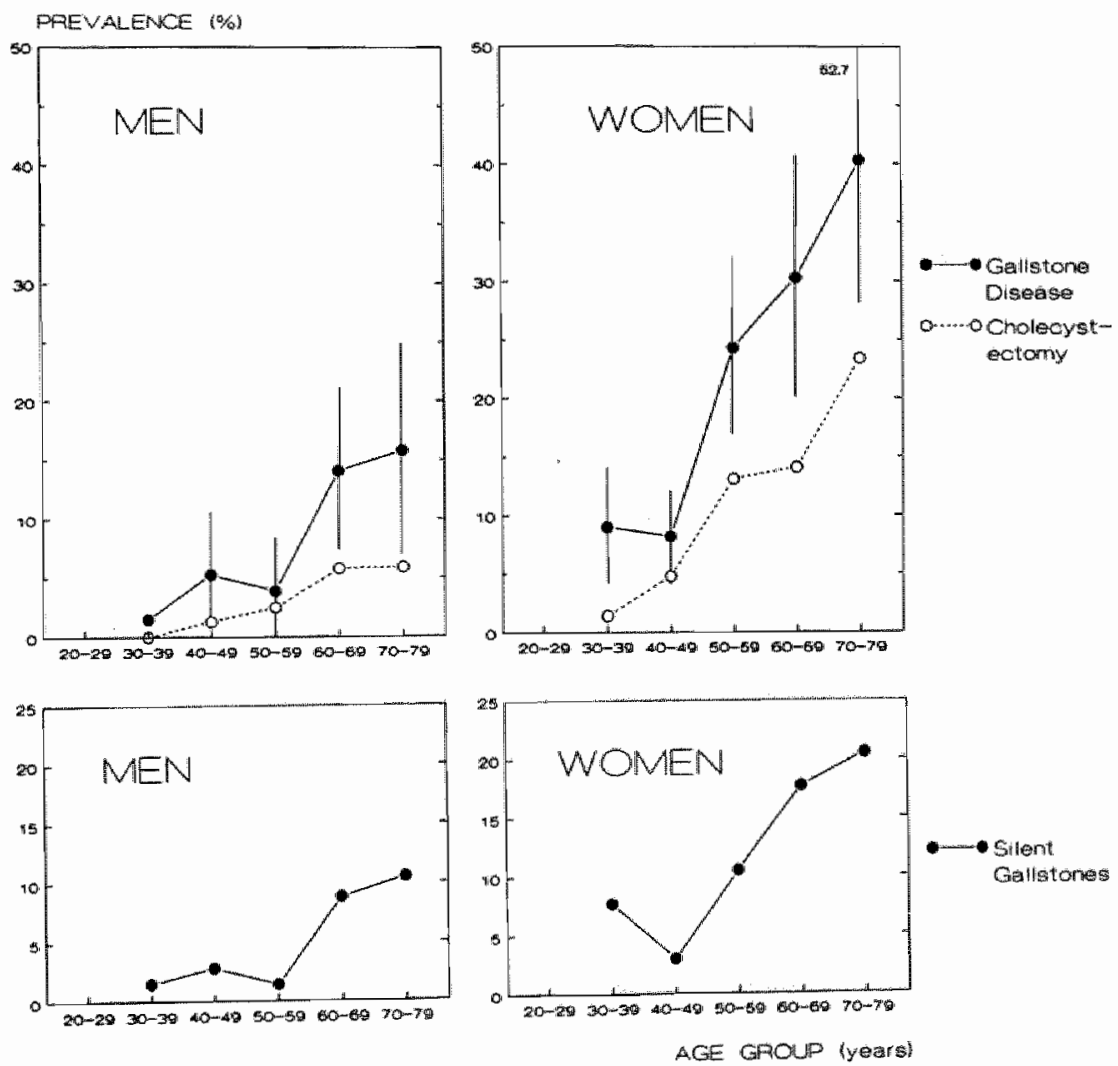

FIGURE 2 Prevalence of cholecystectomy and total gallstone disease (including cholecystectomy; vertical bars indicate $95 \%$ confidence intervals, upper graphs), and prevalence of silent gallstones in subjects with an intact gallbladder (lower graphs). 
As expected, all prevalences appeared to increase with age. The prevalence of cholecystectomy increased with age to reach $6 \%$ in men and $23 \%$ in women in the oldest age category. Diagnosed gallstones were reported by only one man and by $1 \%$ to $2 \%$ of women over the age of 40 years. The proportion of subjects with gallstone disease who had undergone cholecystectomy was $39 \%$ for men and $50 \%$ for women of all age groups combîned.

All other West European studies except one ${ }^{17}$ provided enough information to estimate prevalences in the age range of 40 to 60 years. The results are given in table 2 .

TABLE 2 Standardized prevalence (\%) of galistone disease in West European screening studies (age 40-60 years)

\begin{tabular}{|c|c|c|c|c|c|}
\hline \multirow[t]{2}{*}{ Country } & \multirow[t]{2}{*}{ Population } & \multirow[t]{2}{*}{ Year* } & \multirow[t]{2}{*}{ Reference } & \multicolumn{2}{|c|}{ Prevalence } \\
\hline & & & & Men & Women \\
\hline Nonway & Bergen & 1983 & 19 & $21 \%$ & $27 \%$ \\
\hline Sweden & Malmó & 1979 & 15 & & $20 \%$ \\
\hline Denmark & Province of Copenhagen & 1982 & 1 & $7 \%$ & $14 \%$ \\
\hline \multirow[t]{2}{*}{ UK } & town in Wales & 1970 & 11 & $5 \%$ & $13 \%$ \\
\hline & Oxford & 1983 & 16 & $21 \%$ & \\
\hline \multirow[t]{2}{*}{ Italy } & village at Lake Garda & 1980 & 12 & $10 \%$ & $22 \%$ \\
\hline & civil servants Rome & 1980 & 13,14 & $11 \%$ & $14 \%$ \\
\hline Netherlands & Academic Hospittal Maastricht & 1985 & & $5 \%$ & $16 \%$ \\
\hline
\end{tabular}

*Approximate year about which the study was carried out

\section{DISCUSSION}

\section{Internal validity}

Preferential participation or nonresponse by subjects who had undergone cholecystectomy or knew they had gallstones is a potentially important source of bias. This would only have affected the prevalences of cholecystectomy and diagnosed gallstones ("known gallstone disease"). Secondary refusal of ultrasound screening after participation in the interview can hardly have introduced any nonresponse bias, since both the refusing subject and the investigators were unaware of the contents of the subjects' gallbladders.

For an accurate estimation of low prevalences high diagnostic specificity is critical. The diagnostic validity of ultrasound for the diagnosis of gallstones is estimated to be high $^{25}$. In the Academic Hospital Maastricht we have estimated specificity of routine ultrasound examination of gallbladder stones to be $97 \%$ during the study period, at a sensitivity of $95 \%$. Assuming these test characteristics to be true, and given an observed prevalence of silent gallstones in men of $4.8 \%$ (18 of 378 men with conclusive ultrasound exams, table 1), then the real prevalence of silent gallstones in men can be estimated to be only $1.9 \%$ (approach: if $p$ is the real prevalence, then the observed prevalence is 
equal to sensitivity $\times p+(1-$ specificity $) \times(1-p))$. By analogy, the real prevalence of silent gallstones in women, at an observed prevalence of $8.7 \%$ ( 45 of 516 ), would be $6.2 \%$.

The accuracy of our estimation of the prevalence of silent gallstones would have been greatly increased if positive (and inconclusive) ultrasound results had been followed by oral cholecystography. This strategy was chosen in a study of women in Rome ${ }^{\text {t. }}$. In addition, oral cholecystography was performed in a sample of women with negative ultrasound examinations. In that study the estimated prevalence of silent gallstones, based on the combined data from both diagnostic procedures, was almost equal to that based on ultrasound alone ( $4.9 \%$ in all women). This indicates that the degree of overestimation of low prevalences of silent gallstones by ultrasound examination may be modest.

\section{External validity}

The question can be raised whether the results apply to the general population of The Netherlands. An earlier autopsy study did not show great differences in the life-time prevalence of gallstone disease between Maastricht and five other cities in various parts of the Netherlands'. In addition, the representativeness of the hospital population for the general population of Maastricht is of interest. To some extent this could be assessed with the help of data from a general population survey of a random sample of residents of the catchment area of our hospital ${ }^{26}$. In women, cholecystectomy was reported almost one-third less often in the general population than in the hospital population. Moreover, the body mass index of women in the general population was lower than in the hospital population, the difference representing an average of $3 \mathrm{~kg}$ body weight. Both these findings suggest that the real prevalences of cholecystectomy and gallstone disease in the general population may be somewhat overestimated by the findings in the hospital population, at least in women.

\section{Conclusion}

The considerations of the diagnostic validity of ultrasound screening for silent gallstones and of the representativeness of the hospital population suggest that the prevalence of gallstone disease in the general population may be somewhat lower than the prevalence found in our hospital population. When the results of this study are compared with those in other West European countries, these considerations are to be taken into account. We conclude that the prevalence of gallstone disease in Mastricht males is as low as the lowest prevalence found elsewhere (Wales), whereas the prevalence in Matastricht females lies on the lower side within the range of the prevalences found in other West European countries.

\section{REFERENCES}

1. Flekken P, Knipschild P. Galstenen en kanker van de galblaas-een ecologisch onderroek. Tijuschr Soc Geneesk 1982;60:868-869.

2. Bouchier LAD. Postmortem study of the frequency of gallstones in patients with cirrhosis of the liver. Gut 1969;10:705-710. 
3. Hogan J, Loncrgan M. Holland PDJ. The incidence of chole- lithiasis in an antopsy series. J Irish Med Assoc 1977, 700608-6i11.

4. Kalow $A$, Delidou $A$, Kordosis Th, Archimandritis $A$, Gaganis $A$, Angelopoulos $B$. The incidence of gallstones in Greece; an autopsy study. Acta Hepato-Galstroenterol 1977;24:20-23.

5. Lindstrom CG, Frequency of gallistone disease in a well-defined Swedish popullation. A prospective stidy in Malmo. Scand J Gastroenterol 1977;12:341-346.

6. Barker DJP, Gardner MJ, Power $C$, Hutt MSR. Prewalence of gallstones at necropsy in mine Britsh towns: a collaborative study. Br Med J 1979;2:1389-1392.

7. Bateson MC Galibladder disease and cholecystectomy rates are independemtly variable. Lancet $1984 ;$ ii: $621-624$.

8. Godrey PJ, Battes $\mathbb{T}$, Harrison M, King MB, Padley NR. Gallstones and mortality: a study of all gallstone related deaths in single health district. Gut 1984;25:1029-1033.

9. Domellof $\mathrm{L}_{*}$ Lowenfels $\mathrm{AB}$, Sipponen $\mathrm{P}$. Prevalence of gallstones in Finland: an autopsy study in the Helsinki area. Scand J Gastroenterol 1984;19:761-764.

10. Balzer $\mathrm{K}$; Goebell $\mathrm{H}$, Breuer $\mathrm{N}$, Rüping $\mathrm{KW}$, Leder $\mathrm{LD}$. Epidemiology of gallstones in a German industrial town (Essen) from 1940-1975. Digestion 1986;33:189-197.

11. Bainton D, Dawies GT, Evans KT, Gravelle IH. Gallbladder disease. Prevalence in a South Wales industrial town. N Engl J Med 1976;294:1147-1149.

12. Barbara L, Sama C, Morselli Labate AM, Taroni F, Rusticali AG, Festi D, Sapio C, Roda E,

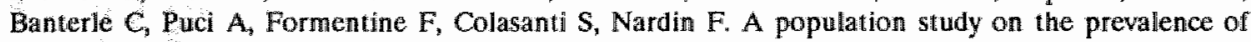
gallstone disease: the Sirmione Study. Hepatology 1987;7:913-917.

13. Rome Group for Epidemiology and Prevention of Cholelithiasis (GREPCO). Prevallence of gallstone disease in an Italian adult female population. Am J Epidemiol 1984;119:796-805.

14. Rome Group for Epidemiology and Prevention of Cholelithiasils (GREPCO). The epidemiology of gallstone disease in Rome, Italy. Part I. Prevalence data in men. Hepatology 1988;8:904-906.

15. Janzon L, Aspelin $P$, Eriksson $S$, Hildell J, Trehl E, Oestberg $H$. Ultrasonographic screening for gallstone disease in middle-aged women. Detection rate, symptoms and biochemical features. Scand J Gastroenterol 1985;20:706-710.

16. Pixley $F_{b}$ Wilson $D$, McPherson $K$, Mann $J$ Effect of vegetarism on development of gallstones in women. Br Med J 1985;291:11-12.

17. Rhomberg HP, Judmair G, Lochs A. How common are gall stones? Br Med J 1984;289:1002 (letter).

18. Jorgenson T. Prevalence of gallstones in a Danish population. Am J Epidemiol 1987;126:912-921.

19. Glambek I, Kvale G, Amesjo B, Soreide O. Prevalence of gallstones in a Norwegian population. Scand J Gastroenterol 1987;22:1089-94.

20. Thijs $C$, Knipschild P, Brombacher P. Serum lipids and gallstones- a case-control study. (submitted for publication).

21. Thijs C, Rinkens P, Knipschild P. Dyspepsie en galstenen. Tijdschr Soc Gezondheidszorg $1983 ; 64: 275$.

22. Crade M. Comparison of ultrasound and oral cholecystogram in the diagnosis of gallstones. In: Taylor KWJ, ed. Clinics in diagnostic ultrasound. Volume 1. Churchill Livingstone, New York, 1979: 123-135.

23. Cooperberg PH. Realtime ultrasonography of the gallbladder. In: Winsberg I, Cooperberg PL, eds. Clinics in diagnostic ultrasound. Volume 10. Churchill Livingstone, New York, 1982: 49-69.

24. Efron $B$. The Jackknife, the bootstrap, and other resampling plans. Society for industrial and applied mathemathics, Philadelphia, 1982.

25. Campbell WL Right upper quadrant abdominal pain? Acute cholecystitis. In: Straub WH, ed. Manual of diagnostic imaging. Little, Brown \& Company, Boston, 1984.

26. Thijs CT, van Engelshowen JMA, Knipschild PG. Een echografisch onderzoek naar de prevalentie van galsteenziekte in Maastricht en omstreken. Ned Tijdschr Geneeskd 1989;133:110-4. 


\section{BESCHOUWING}

\section{Risicofactoren voor galsteenziekte}

\section{Serumlipiden en alcoholgebruik}

Het bestaan van een verband tussen serumlipiden en galsteenziekte werd in ons onderzoek en inmiddels ook in onderzoek van anderen bevestigd (artikel 2). Het ligt voor de hand om aan te nemen dat deze relatie causaal is, ook omdat is gebleken dat serumlipiden verband houden met een intermediaire stap in de vorming van galstenen, de verzadiging van gal met cholesterol ${ }^{1}$. Men kan nu veronderstellen dat voeding via invloed op de serumlipiden effecten heeft op de kans op het krijgen van galstenen, zoals dit bijvoorbeeld ook bij coronaire hartziekte het geval lijkt te zijn.

Toch dienen enigen nuanceringen te worden gemaakt bij deze veronderstelling. Het is niet geheel uitgesloten dat veranderingen van de galblaasfunctie die plaatsvinden bij aanwezigheid van galstenen, de galzout- en cholesterolhuishouding beïnvloeden. Dit is echter niet erg waarschijnlijk. Eerder kan men denken aan onderliggende constitutionele determinanten, die samenhangen met het galzout-, cholesterol- en energiemetabolisme, en waarvan serumlipiden en vetzucht indicatoren zijn. Wel vonden wij aanwijzingen dat serumlipiden dichter bij het pathogenetisch mechanisme staan dan de al langer bekende risicofactor vetzucht. Ook een samenhang van galstenen met het plasma-insulinegehalte is beschreven ${ }^{2}$. Een verdere nuancering van de rol van serumlipiden naar analogie van coronaire hartziekte is dat cholesterolverlaging door dieet of geneesmiddelen (clofibraat, nicotinezuur) juist een verhoogde risico op galsteenzjekte met zich mee lijkt te brengen ${ }^{3}$. In tegenstelling tot coronaire hartzjekte vertoont galsteenziekte geen relatie met het totale cholesterolgehalte in het serum. In ons onderzoek vonden we zelfs een zwak negatief verband.

Een causale relatie is het meest overtuigend te evalueren in experimenteel onderzoek. Er zijn veel experimentele resultaten op het gebied van voeding en serumlipiden, al minder op het gebied van voeding en verzadiging van gal met cholesterol, en geen enkele op het gebied van voeding en het optreden van galsteenziekte bij de mens. In het meeste niet-experimentele onderzoek is moeilijk uit te maken aan welk van de bestanddelen een effect kan worden toegeschreven.

Het meest consistent komt de rol van serumlipiden tot uiting in de relatie tussen alcoholgebruik en galstenen. Experimenteel is aangetoond dat matig alcoholgebruik het 
serum HDL-cholesterol verhoogt en de galverzadiging verlaagt ${ }^{*}$. In een experiment bij prairiehonden met een extreem dieet dat bij de helft tot vorming van galstenen leidt, werd een beschermend effect van alcoholsuppletie gevonden ${ }^{5}$. Hiermee is de causaliteit van de relatie tussen alcoholgebruik en het optreden van galstenen plausibel gemaakt. Voor andere factoren die van inwloed zijn op de serumlipiden, is dat veel minder het geval (energie-inname, voedingsvetten, voedingsvezel, lichamelijke activiteit, roken) ${ }^{3}$.

De mate van het beschermend effect van alcoholgebruik is inmiddels in verschillende niet-experimentele onderzoeken bepaald. Een samenvatting hiervan werd gegeven in het derde artikel. Voor symptomatische galsteenziekte zijn relatieve risico's gevonden van om en nabij 0,6. In ons eigen onderzoek werd gedemonstreerd dat het beschermend effect overschat wordt als er onvoldoende rekening mee wordt gehouden dat galsteenpatiẻnten hun alcoholgebruik verminderen onder invloed van buikklachten (protopathische vertekening). In geen van de onderzoeken naar symptomatische gallsteenziekte in de literatuur werden afdoende maatregelen genomen om deze overschatting te vermijden. Van het eerste onderzoek waarin protopathische vertekening wrijwel uitgesloten is, kunnen de resultaten binnenkort verwacht worden.

\section{Pilgebruik en zwangerschap}

Eén jaar na de start van ons onderzoek verschenen de resultaten van een Australisch patiënt-controle onderzoek, dat qua onderzoeksopzet veel op het onze lijkt ${ }^{6}$. Voor pilgebruik en het optreden van galsteenziekte werd een relatief risico gevonden van 0,7 . In plaats van te concluderen dat de pil beschermt tegen het optreden van galsteenziekte, trokken de auteurs de conclusie dat de pil het risico tijdelijk verhoogt bij een subgroep van vrouwen die vatbaar zijn voor het effect. Indien in een patiënt-controle onderzoek de deelnemers lang geleden waren blootgesteld aan de risicofactor, en de effectperiode reeds verstreken is, zijn alle personen al uitgeselecteerd die de ziekte ten gevolge van de blootstelling hebben gekregen. In dat geval mist men het effect. Dit kan worden voorkómen door risicoperiodes te specificeren, zoals gedemonstreerd in het artikel over zwangerschap en galsteenziekte (artikel 4). Niet lang geleden zijn pas de principes geformuleerd om de risicomaat waar het eigenlijk om gaat, het extra risico, te bereken uit risicoperiode-specifieke incidentiedichtheden. Dit vereist echter een gemodificeerde patiënt-controle onderzoeksopzet? ${ }^{7}$. Er zijn ons geen onderzoeken bekend waarin deze principes al zijn toegepast.

Bij het formuleren van de hypothese over pilgebruik en galsteenziekte voorafgaand aan het onderzoek werd reeds twijfel uitgesproken over een verhoogt risico op langere termijn (artikel 1). Dit werd bevestigd door het hierboven genoemde Australische onderzoek. Ook voor zwangerschap vonden wij een tijdelijk effect op het optreden van galsteenziekte, waarbij galsteenziekte in de eerste vijf jaar na zwangerschap ruim tweemaal zo vaak optreedt (artikel 4). In eerder onderzoek werd geen rekening gehouden met een tijdelijk effect en werden risicoperiodes onvoldoende gespecificeerd. Dit kan gedeeltelijk verklaren waarom de onderzoeken zeer uiteenlopende resultaten toonden. Bij pilgebruik en galblaasziekte wezen wij op hetzelfde euvel in onze samenvatting van de literatuur (artikel 5).

In deze samenvatting werd ook beargumenteerd waarom aanvankelijke onderzoeken die een relatief risico van 2,0 of hoger rapporteerden, mogelijk een verkeerd beeld 
geven. Steeds betrof het onderzoek met een gebrekkige onderzoeksopzet, dat mogelijk door de extreme (en tevens statistisch significante) bevindingen interessant genoeg werd geacht om gepubliceerd te worden. Wij denken dat het effect hoogstwaarschijnlijk kilein is. Uitgegaande van de bevindingen van de Royal College of General Practitioners' Oral Contraceptives Study (relatieve incidentiedichtheid maximaal 1,3 drie jaar na de start wan pilgebruik) schatten wij dat het extra risico in de orde van grootte is van $0,1 \%$ (artikel 5). Met andere woorden, één op de duizend vrouwen die de pil gebruiken, krijgt hierdoor galsteenziekte.

Ten tijde van de planning van ons onderzoek was het relatieve belang van de destijds gepubliceerde onderzoeken nog niet zo duidelijk, en werd nog uitgegaan wan een te detecteren relatief risico van 2,0 voor de bepaling van de omvang van het onderzoek. Achteraf is duidelijk geworden dat de omvang te klein is om een relatieve incidentiedichtheid van 1,3 te detecteren. Daar komt mog bij dat deelnemers die decennia vóór de diagnose de pil hadden gebruikt, geen informatie meer bijdragen als het effect tijdelijk is. Niettemin vonden we in het eigen onderzoek resultaten die goed pasten bij een zo klein en tijdelijk effect van pilgebruik, echter alleen indien niet werd gecorrigeerd voor mogelijke confounders (artikel 6).

Bij de eerdere onderzoeken over pilgebruik en galblaasziekte werd relatief weinig aandacht besteed aan confounding. De beste onderzoeken corrigeerden wel voor leeftijd en zwangerschappen, maar deden dit niet risicoperiode-specifiek. In slechts én onderzoek werd ook gecorrigeerd voor menarcheleeftijd ${ }^{8}$. Echter, risicoperiode-specifieke correctie voor een groot aantal confounders bleek in ons eigen onderzoek een sterke invloed te hebben op resultaten. Mogelijk speelt een grote mate van confounding al het eerdere onderzoek parten.

Het onderzoek tot dusver heeft vooral duidelijk gemaakt dat epidemiologisch onderzoek geen goed antwoord kan geven op de vraag hoe groot het effect is van pilgebruik op het optreden van galsteenziekte. Om de waarschijnlijk kleine verschillen in het risico op galsteenziekte te kunnen kwantificeren dient van een immens groot aantal vrouwen informatie beschikbaar te zijn over hun hele geschiedenis van pilgebruik, inclusief het merk en het optreden van zwangerschappen. Dergelijke gegevens zijn zelfs in het toch zeer uitgebreide gegevensbestand van de grootste ziektekostenverzekeraar in de Verenigde Staten niet voorhanden". Bij het zoeken naar steeds veiligere orale anticonceptiva is het daarom realistischer om pathogenetische effecten te bestuderen, zoals de invloed op de galverzadiging en de galblaasfunctie ${ }^{10}$.

\section{Lijnen en vetzucht}

Een van de bestudeerde risicofactoren was het volgen van vermageringskuren ("lijnen"). Hier was het de kunst om het galsteenbevorderend effect van gewichtsreductie te scheiden van het effect van het uitgangsgewicht. Immers, mensen die willen vermageren, zijn relatief dik en hebben daardoor al een hoger risico op galsteenziekte. De resultaten van het onderzoek geven aan dat lijnen niet gepaard gaat met een belangrijk verhoogd risico, en dat vooral dikke mensen juist eerder baat hebben van het bereiken van een lager lichaamsgewicht (artikel 7).

In hetzelfde onderzoek werd het verband bestudeerd tussen het optreden van acute galsteenziekte en vetzucht (gemeten als Quetelet-index) op verschillende tijdstippen in 
het verleden: in het jaar voorafgaand aan de diagnose, en 5,10 en 15 jaar eerder. De Quetelet-index bleek voldoende te variëren over de tijd bij de individuele deelnemers om na te gaan bij welke tijdsrelatie het verband het sterkste was. Dit bleek bij 5 jaar voor de diagnose te zijn, hetgeen wijst op een gemiddelde latentietijd van omstreeks 5 jaar voor acute galsteenziekte.

Dit werpt nieuw licht op de stappen in het ontstaan van galsteenziekte. De verzadiging van gall met cholesterol is hoger bij vetzucht, zodat zich sneller galstenen kunnen vormen. Een volgende stap is het symptomatisch worden van deze galstenen. Indien vetzucht deze tweede stap niet ook bevordert, zou de latentietijd minstens zo lang zijn als de periode tussen galsteenvorming en het optreden van symptomen. In een onderzoek waarin galstenen konden worden gedateerd aan de hand van radioactieve fallout, is een latentietijd tussen het ontstaan van galstenen en galblaasoperatie gevonden van gemiddeld 12 jaar (range 2 tot 20 jaar) ${ }^{11}$. De in ons onderzoek gevonden kortere latentietijd voor acute galsteenziekte wijst derhalve op een oorzakelijke rol van vetzucht bij het ontstaan van symptomen. Het is niet duidelijk of dit tot stand komt door een causaal effect van vetzucht op het optreden van acute complicaties van reeds bestaande galstenen, of op de vorming van een type galsteen dat snel tot acute complicaties aanlejding geeft. De rol van vetzucht bij het optreden van symptomen van galstenen wordt bevestigd door de recente bevinding in een groot follow-up onderzoek naar de prognose van asymptomatische galstenen ${ }^{12}$. Dit ondersteunt eerdere speculaties dat factoren die bij de vorming van galstenen betrokken zijn tevens de ontsteking van de galblaas bij reeds aanwezige galstenen bevorderen ${ }^{13}$.

\section{Peulvruchten}

Een andere voedingsfactor die bestudeerd kon worden was de consumptie van peulvruchten (artikel 8). Tot onze verbazing vonden we een tegengesteld effect aan wat de hypothese voorspelde. Het regelmatig nuttigen van peulvruchten ging in ons onderzoek gepaard met een tweemaal zo laag risico op galsteenziekte dan het zelden eten daarvan. Als verklaring lag het meest voor de hand dat ook hier protopathische vertekening in het spel was: galsteenpatiënten met langer bestaande buikklachten kunnen zwaar op de maag liggende voedingsmiddelen zijn gaan vermijden, en dit patroon als normaal hebben gaan ervaren. Het ontbreken van een relatie tussen de consumptie van peulvruchten en het bestaan van buikklachten maakte deze verklaring echter minder waarschijnlijk. Confounding door andere voedingsfactoren is eveneens weinig waarschijnlijk, omdat alleen een redelijk sterke risicofactor het gevonden verband kan verklaren. Een zo sterke risicofactor is niet bekend.

Als alternatief opperen we dat in peulvruchten zowel beschermende als galsteenbevorderende bestanddelen zitten, en dat in Nederland vooral peulvruchten gegeten worden met beschermende bestanddelen. Dit sluit aan bij de elkaar tegensprekende resultaten in onderzoeken naar het effect van woedingsvezel op de galverzadiging ${ }^{3}$.

\section{Zonlicht en huidlype}

Bij een systematische zoekactie in de literatuur werd geen enkel eerder epidemiologisch onderzoek gevonden naar het effect van blootstelling aan zon of licht en het optreden 
van galstenen bij personen met een lichte huid. Desondanks is wel gespeculeerd over een pathofysiologische basis voor een dergelijk effect. Ten eerste treedt onder invioed van daglicht in de huid isomerisatie van ongeconjugeerd bilirubine (een bloedafbraakproduct) op, dat vervolgens via de gal wordt uitgescheiden ${ }^{14}$. Echter, alleen verhoogde bloedafbraak (hemolyse) is beschreven als risicofactor bij de vorming van galstenen, en dan nog alleen voor zwarte pigmentstenen. Deze zijn in geïndustrialiseerde landen zeer zeldzaam ${ }^{15}$. Ten tweede werd in galstenen van twee patiënten de aanwezigheid wan isomeren van huidpigment aangetoond ${ }^{16}$. Deze isomeren ontstaan onder invloed van zonlicht (foto-isomerisatie). Een plotseling verhoogde productie van huidpigment treedt vooral op mensen met een lichte huid bij zonnebrand. Dit laatste mechanisme lijkt alleen een mogelijke rol te spelen bij het ontstaan van andere dan cholesterolstenen; de twee patiënten hadden bruine pigmentstenen, respectievelijk gemengde stenen (pigment/ cholesterol).

Op het eerste gezicht wekt het misschien verbazing dat inderdaad werd gevonden dat galstenen vaker voorkwamen bij mensen die ondanks een licht huidtype toch vaak zonnebaadden (artikel 9). De meeste patiënten in het onderzoek zullen immers cholesterolstenen hebben gehad. Echter, om in de relatief kleine risicogroep van zonnebaders met een gevoelige huid een relatief groot aantal pigmentstenen te vinden hoeft het totale aandeel van dit type steen nog niet groot te zijn.

Aangezien dit het eerste onderzoek is naar de relatie zonlicht, huidtype en het optreden van galstenen, is nieuw onderzoek nodig om deze relatie te bevestigen, zowel epidemiologisch als pathogenetisch. Epidemiologisch onderzoek kan uit overwegingen van efficiëntie het beste gericht worden op pigmentstenen.

\section{Methodologie}

Ik wil dit proefschrift afsluiten met enkele kanttekeningen bij de methodologie van etiologisch onderzoek, naar aanleiding van de ervaringen met het onderzoek naar oorzaken van galsteenziekte.

\section{Vraagstelling}

Er verschijnen de laatste tijd regelmatig resultaten van grote screeningsonderzoeken, waarin gezonde vrijwilligers echografisch werden gescreend op het bestaan van galstenen. Hierin worden ook risicofactoren voor het aanwezig zijn van galstenen bestudeerd. Er is daarentegen relatief weinig aandacht voor risicofactoren voor symptomatische galsteenziekte. Vanuit klinisch oogpunt is het interessant te weten waardoor galstenen symptom matisch worden. Dat geldt met name nu de diagnostiek van galstenen weinig belastend is voor de patiënt (echografie), en bij aspecifieke klachten een therapeutisch dilemma optreedt: profylactisch opereren (of galsteenoplossen en/of vergruizen) of niet. Ook ons eigen onderzoek was vooral gericht op het ontstaan van galstenen. In nieuw onderzoek zou vooral meer aandacht kunnen worden besteed aan determinanten van het symptomatisch worden van 'stille' galstenen. 


\section{Vertekening}

Aangezien vertekening vaak maar gebrekkig te beheersen is, is het nuttig vooraf hypothesen op te stellen over de meest waarschijnlijke mechanismen van vertekening, en deze in de specifieke onderzoekssituatie te evalueren. Zo kon in dit proefschrift protopathische vertekening worden bestudeerd in de relatie van galsteenziekte met alcoholgebruik en peulvruchten. Als het niet mogelijk is gegevens te verzamelen die behulpzaam zijn bij het kwantificeren van de vertekening, kan men desnoods zijn toevlucht nemen tot een analyse van de gevoeligheid van het waargenomen effect van de risicofactor voor veronderstelde vormen van vertekening (sensitiviteitsanalyse). Telkens zal moeten worden nagegaan of de resultaten stand houden in analyses waarin steeds van verschillende veronderstellingen wordt uitgegaan.

\section{Confounding}

De bestudeerde risicofactor wordt conceptueel vaak gebrekkig afgegrensd van andere risicofactoren. Dit kan er toe leïden dat intermediaire risicofactoren soms ten onrechte wordt aangemerkt als een confounder. In dat geval wordt er ten onrechte voor gecontroleerd (bijwoorbeeld, door het voorkómen van zwangerschap kan pilgebruik beschermen tegen het optreden van galsteenziekte). Het is duidelijk dat voor verschillen in andere risicofactoren aan het begin van de blootstelling moet worden gecorrigeerd. Voor een verschil dat optreden ná de start van de blootstelling is dit minder vanzelfsprekend. Voorzover dit verschil een gevolg is van de blootstelling aan de bestudeerde risicofactor, is er sprake van een intermediaire factor; voorzover het verschil onafhankelijk ervan optreedt is er sprake van een confounder. In niet-experimenteel onderzoek kan dit natuurlijk niet uit elkaar worden gehouden, en is niet duidelijk of er well of niet voor een dergelijke factor moet worden gecontroleerd. Het veiligste is het om analyses te doen met en zonder controle voor de betreffende factor, en te bekijken of de uitkomsten verschillen. Een analoog probleem is het omgaan met constitutionele factoren die zowel intermediare factor als confounder kunnen zijn (bijvoorbeeld: lichaamsgewicht in de relatie lijnen-galsteenziekte). Om deze problemen te kunen voorzien en adekwaat aan te kunnen pakken is het noodzakelijk veronderstellingen te maken over het werkingsmechanisme. Bovendien is het nodig dat risicoperiodes goed worden gespecificeerd: telkens moet een begintijdstip voor de blootstelling aan de bestudeerde risicofactor en de confounders worden gekozen.

\section{Specificatie van hypothesen}

De hier geschetste problemen nopen dus tot een betere specificatie van hypothesen over de relatie tussen verschillende risicofactoren, het werkingsmechanisme, latentietijd en effectperiode, en vertekening. In publicaties van etiologisch onderzoek van galsteenziekte valt de grote mate van vaagheid in de onderzochte hypothesen op. De meeste auteurs lijken zich niet a priori te willen laten wastpinnen op gespecificeerde hypothesen. Men controleert voor alle risicofactoren die men maar heeft gemeten, zonder zich erom te bekommeren of niet ten onrechte voor intermediaire factoren wordt gecontroleerd. Zelden worden veronderstellingen geuit over latentietijd en de duur van het effect. Aanvullende gegevens die behulpzaam zouden kunnen zijn bij het inschatten van de mate van vertekening worden zelden gezien. 


\section{Implicaties voor onderzoeksopzet en analyse}

De hier bepleitte grotere aandacht voor specificatie van hypothesen heeft verscheidene implicaties voor de opzet van onderzoek, de analyse en de publicatie van de resultaten. De neiging bestaat om in etiologisch onderzoek meer oorzaken tegelijk te bestuderen. In patiënt-controle onderzoek lijkt dit ook handig, omdat in de analyse toch ai voor andere risicofactoren moet worden gecontroleerd. Het is echter de vraag of het bij het opzetten van onderzoek wel zo verstandig is om verschillende vraagstellingen te combineren. Als al niet voor iedere vraagstelling een eigen onderzoeksopzet wordt gemaakt, dan verdient iedere vraagstelling in ieder geval wel een aparte statistische analyse. Voor iedere te bestuderen risicofactor dient steeds apart te worden overwogen hoe risicoperiodes moeten worden ingedeeld, en welke factoren als confounders moeten worden aangernerkt. In een multivariate analyse worden de covariabelen dan steeds gemodelleerd en als confounder geëvalueerd met als criterium of het waargenomen effect voor de bestudeerde risicofactor verandert. Het is daarom niet adekwaat om meer dan eén risicofactor tegelijk te bestuderen in een multivariate regressie-analyse, laat staan variabelen in het regressiemodel te selecteren in een stapsgewijze procedure op basis van statistische significantie (zogenaamde stepwise regression). Iedere bestudeerde risicofactor verdient daarnaast een aparte evaluatie van andere vormen van vertekening.

Helaas heeft een dergelijke statistische analyse veel meer voeten in aarde dan veelal wordt erkend, en zal veelal door de onderzoeker moeten zelf worden uitgevoerd gezien de benodigde kennis van het werkingsmechanisme en de mechanismen van vertekening. De preoccupatie met het minimaliseren van toevalsbevindingen (het klassieke "hypothese-toetsen") zou plaats moeten maken voor een grotere aandacht voor het evalueren van een scala aan elkaar min of meer uitsluitende en aanvullende hypothesen. Hierbij gaat het steeds om de relatieve waarschijnlijkheid van de hypothesen. Om een analogie met diagnostiek te gebruiken: onderzoek is geen screeningstest maar differentiaaldiagnostiek.

\section{Referenties}

1. Thornton ITR, Heaton $\mathrm{KW}$, MacFarlane DO. A relation between high-density-lipoprotein cholesterol and bile cholesterol saturation. Brit Med $1981: 283: 1352-4$.

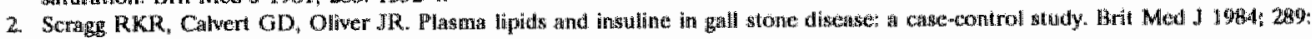
$521-5$.

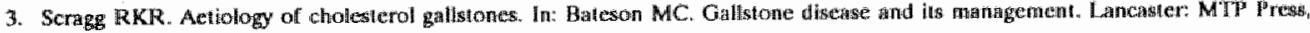
1986.

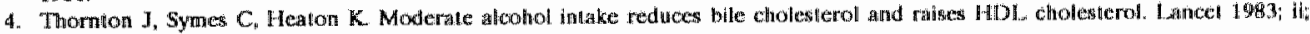
819.22.

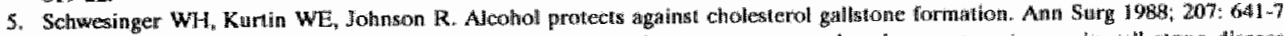

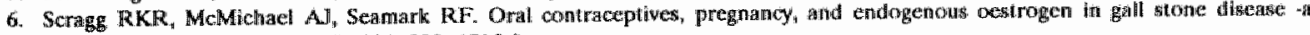
cabecontrol study. Brit Med J 1984; 288: 1795\%.

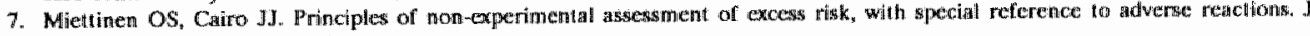
Clin Epidemiod 1989; $42,325-31$.

g. Jorgensen T. Gall stomes in a Datish population: fertility perico, pregnancies, and rewogenows fernalle sex liormones. Gul 1980 ; 29: 4339 .

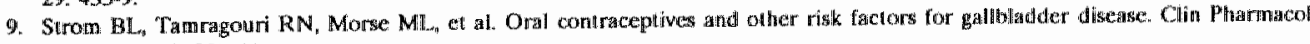
Ther 1986; 39: $335-41$.

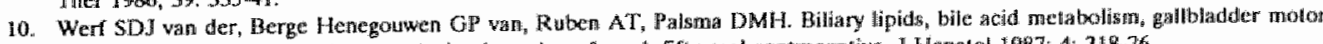

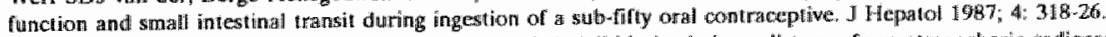

11. Mok HY, Druffel ER, Rampone WM. Chronology of choletithiasis, dating gallstones fromatmospheric radiocarbon produced by nuclear bomb explosions. N Engl I Med 1986; 314: 1075-7. 


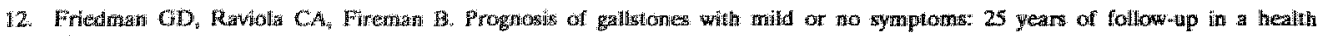

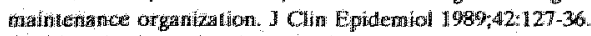

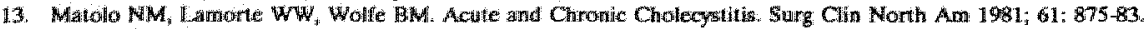

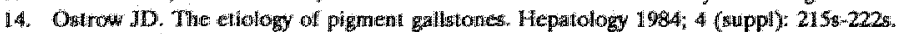

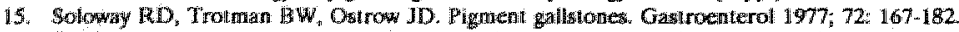

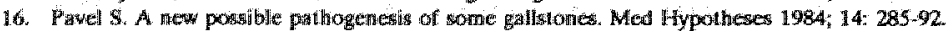




\section{SAMENVATTING}

In dit proefschrift wordt een aantal onderzoeken gepresenteerd haar de etiologie (oorzaken) van galsteenziekte. Voorop stonden alcoholgebruik en het gebruik van orale anticonceptiva (de "pil"), en de rol van serumlipiden (vetten in het bloedserum). Deze risicofactoren, en enkele andere, werden in patiënt-controle onderzoek bestudeerd.

De kern van het proefschrift wordt gevormd door een reeks van tien artikelen. Het eèrste is een beschrijving is van de vraagstelling. De volgende negen rapporteren de onderzoeken per onderwerp. Deze negen artikelen zijn Engelstalig, maar worden telkens voorafgegaan door een Nederlandse samenvatting. In een inleidend hoofdstuk worden de achtergronden geschetst. Een afsluitend hoofdstuk geeft een globale beschouwing over de resultaten van de onderzoeken. Tevens geef ik daarin mijn visie op methoden van etiologisch onderzoek.

De opbouw van het proefschrift uit artikelen brengt helaas met zich mee dat er enige herhaling optreedt in de beschrijving van de onderzoeksmethode. Daar staat tegenover dat ieder artikel als een zelfstandige eenheid gelezen kan worden. De meeste lezers die ik bij het schrijven van dit proefschrift voor ogen had, zullen niet op beide gebieden, etiologie van galsteenziekte en methoden van epidemiologisch onderzoek, even deskundig zijn. Om die reden heb ik de bespreking wan biomedische en epidemiologische achtergronden in de inleiding en de beschouwing trachten te beperken tot het hoogst noodzakelijke, en mij bediend van de Nederlandse taal.

Het eerste artikel werd geschreven bij de start van het onderzoek, en geeft de toenmalige achtergronden en de centrale hypothesen weer. Alcoholgebruik zou kunnen beschermen tegen het optreden van galsteenziekte door een invloed op de serumlipiden, met name verhoging van het HDL-cholesterol. Ook andere factoren die verband houden met serumlipiden stonden daarmee in de belangstelling: het gebruik van orale anticonceptiva ("de pil"), vetzucht en afvallen ("lijnen").

De relatie tussen serumlipiden en galsteenziekte wordt belicht in het tweede artikel. $W_{i j}$ vonden dat het risico het hoogste is als tegelijkertijd het serumgehalte aan HDLcholesterol laag en aan triglyceriden hoog is. Resultaten van multivariate analyse geven 
een aanwijzing dat serumlipiden dichter bij het pathogenetisch mechanisme staan dan vetzucht.

Het derde artikel betreft de relatie tussen alcoholgebrwik en galsteenziekte. Speciale aandacht wordt besteed aan het probleem dat mensen met galstenen vanwege klachten hun alcoholgebruik minderen, hetgeen de resultaten van niet-experimenteel onderzoek kan vertekenen (protopathische vertekening). In een serie patiënt-controle onderzoeken zijn de consequenties van verschillende onderzoeksopzetten geëvalueerd. Het onderzoek demonstreert het bestaan van protopathische vertekening in onderzoek naar alcoholl en galsteenziekte. Deze vertekening heeft mogelijk geleid tot een overschatting van het beschermend effect van alcohol in eerder onderzoek.

In het vierde artikel wordt het belang van specificatie van risicoperiodes in etiologisch onderzoek gedemonstreerd aan de hand van een onderzoek naar de relatie tussen zwangerschap en galsteenziekte. Het effect van zwangerschap lijkt tijdelijk te zijn. In de eerste vijf jaar na een zwangerschap is treedt galsteenziekte tweemaal zo vaak op, daarna wordt geen effect meer waargenomen.

In een systematische samenvatting van de literatuur over pilgebruik en galsteenziekte (artikel 5) stellen we dat in de meeste onderzoeken risicoperiodes onvoldoende zijn gespecificeerd om de grootte van het veronderstelde tijdelijke effect te kunnen schatten. Niettemin wijst het totaal aan informatie wel op een tijdelijk en klein effect. Eigen onderzoek over pilgebruik en galsteenziekte (artikel 6) geeft resultaten die in overeenstemming zijn met een tijdelijk verhoogd optreden van galsteenziekte. Echter, na controle voor een groot aantal andere risicofactoren veranderen de resultaten sterk. Dit suggereert dat de schattingen van het effect van pilgebruik sterk kunnen worden vertekend door risicoperiode-specifieke confounding. Helaas blijft onduidelijk of het risico hierdoor overschat of juist onderschat wordt.

In een volgend onderzoek wordt gepoogd de effecten van vetzucht en afvallen ("lijnen") op het optreden van acute galsteenziekte te ontwarren (artikel 7). De resultaten wijzen erop dat bij personen met vetzucht lijnen niet leidt tot een verhoogd risico op acute gallsteenziekte op langere termijn.

De laatste drie artikelen beschrijwen onderzoek dat min of meer een uitvloeisel is van het centrale onderzoek. Toen de gegevens voor de bovenstaande onderzoeken reeds verzameld waren, verscheen een nieuwe hypothese in de literatuur: het eten van peulvruchten zou galstenen kunnen veroorzaken. Deze hypothese kon met toewallig in ons onderzoek voorhanden gegevens worden geëvalueerd. Tegen de verwachting in wordt gevonden dat het risico op galsteenziekte tweemaal zo laag is bij het regelmatig nuttigen van peulvruchten (artikel 8). In het negende artikel wordt verslag gedaan van een onderzoek naar de vraag of mensen met een licht huidtype een verhoogd risico op galstenen krijgen, als zij desondanks vaak zonnebaden. Als nevenproduct van de onderzoeken komen gegevens op tafel over het vóórkomen van galstenen in Nederland (artikel 10). De prevalentie neemt toe met de leeftijd. $16 \%$ van de mannen en $40 \%$ van de vrouwen in de hoogste leeftijdscategorie heeft galstenen, of heeft ze ooit gehad; van deze mannen heeft ruim éénderde een galblaasoperatie ondergaan; bij vrouwen was dit de helft. 


\section{DANKWOORD}

Mijn eerste woord van dank geldt de ruim 1400 deelnemers aan het onderzoek. Zonder hun geduld om een uur lang vragen te beantwoorden was van dit onderzoek niets terechtgekomen. Hetzelfde geldt voor de niet aflatende inzet van de interviewers. Het kost heel wat vasthoudendheid en geduld om de noodzakelijke nauwkeurigheid te bereiken. Daarnaast is het steeds weer spannend om een nieuwe kandidaat voor het onderzoek te benaderen, uitleg te geven, en te vragen om medewerking van Cor Pooters van bureau Research en Marketing te Heerlen leerden wij de kneepjes van het interviewen. Speciale dank gaat uit naar Anneke Burger en Myra Peereboom, die behalve het afnemen van interviews ook behulpzaam waren bij de verwerking van de vragenlijsten. Harry van Montfort schreef het computerprogramma om inconsistenties in de vragenlijst te signaleren.

In het voormalige ziekenhuis St. Annadal, waar het grootste deel van de gegevensverzameling plaats vond, hebben velen meegewerkt aan het onderzoek. Zonder dat ik iedereen bij naam kan noemen, dank ik hen voor de grote behulpzaamheid. Zeer veel heb ik te danken aan Jos van Engelshoven, die het mogelijk maakte om op zijn afdeling Radiologie patiênten te werven en echografieën te laten uitvoeren ten behoeve van het onderzoek. Gedurende twee jaar was ik bijna dagelijks te gast op de echokamer, waar ik met name Hilde van Deurse bedank voor het extra werk dat mijn onderzoek met zich meebracht. Edith Mater van de Prikdienst was mij steeds behulpzaam als er ergens een extra buisje bloed moest worden afgenomen. C. Degenaar stelde de galsteenanalyses van zijn Klinisch-chemisch laboratorium ter beschikking.

Ook dank ik alle stafleden, arts-assistenten, en medewerkers van de verpleegafdelingen Algemene Heelkunde voor hun behulpzaamheid. Met name gaat daarbij mijn dank uit naar Peter Soeters en Dirk Gouma, die het mogelijk maakten om operatiepatiënten in het onderzoek te betrekken. Speciale dank gaat uit naar Puck Muller en Paul Brombacher van de afdeling Biochemie. Puck, jij wijdde mij in de kunst wan het centrifugeren en pipetteren in. Paul, zonder de inzet van je Klinisch-chemisch laboratorium van het Heerlense de Weverziekenhuis en je grote kennis over serumlipiden hadden we de ruggegraat van het onderzoek moeten missen. Van jullie 
beiden heb ik veel steun gehad door jullie belangstelling in de voortgang van het onderzoek.

Met de afsluiting van activiteiten op helt ziekenhuis was het onderzoek nog maar half af. Pim Assendelft wass als student-assistent behulpzaam bij het opnieuw benaderen van een selectie van deelnemers voor het walideren van de voedingsvragenlijsten en het natrekken van gegevens over pilgebruik bij huisartsen. Lex Volovics hielp mij op weg bij het uitvoeren van logistische regressie analyse met meer geavanceerde computerprogrammatuur, Marion de Leeuw en Sacha van de Crommert was steeds behulpzaam met het voorbereidende computerwerk. Alle leden wan de vakgroep bedank ik voor de gezelligheid en de goede werksfeer. Steeds wanneer ik methodologische problemen te moeilijk vond worden, bracht Pieter Leffers licht in de duisternis. Paula Rinkens die de gegevensverzameling in het ziekenhuis voortzette in het kader van een vervolgonderzoek, verblijdde mij altijd met haar opgewektheid. Paula en Pieter, ik verheug me er op door jullie als paranimfen op de promotie te worden bijgestaan.

Stan Pavel zorgde voor een leuk intermezzo door onze hulp in te roepen voor zijn originele onderzoek naar zonnebaden en huidtype in relatie tot galstenen. Stan, ik heb genoten van onze samenwerking.

Paul Knipschild stond niet alleen aan de basis van het onderzoek, maar ook aan die van mijn carrière als epidemiologisch onderzoeker. Gedurende twee weken keuzeonderwijs tijdens mijn studie geneeskunde wist je mijn interesse voor epidemiologie voorgoed te vestigen. Bij de start van het onderzoek werkte jouw enthousiasme en originaliteit aanstekelijk genoeg om de aanvankelijke tegenslagen te verwerken. Aan het einde ontpopte je je bovendien als een kritisch en perfectionistisch mede-auteur. Waar de publicaties door een methodologisch tintje afwijken van het geijkte, heb ik dat vooral aan jou goede voorbeeld te danken.

Jan Klerkx, die mij wetenschappelijk Engels leerde schrijven, en Bob Wilkinson hebben vele rode pennen aan mijn manuscripten versleten. Bedankt voor jullie vlotte correctiewerk. Thum Aarts is mijn grote leermeester tekstverwerking. Thum, dankzij jou kon ik mijn pen inruilen voor het toetsenbord.

Tenslotte gaat mijn dank uit naar mijn echtgenote Eveline Arnold, mijn beste vriend Alfons Crijnen, en mijn ouders voor hun warme interesse voor mijn beroepsleven. 


\section{CURRICULUM VITAE}

Carel Thijs werd geboren op 6 december 1957 te Heerlen. Hij volgde Gymnasium B aan het Bernardinuscollege te Heerlen, en studeerde Muziek aan het Conservatorium te Maastricht en Geneeskunde aan de Rijksuniversiteit Limburg. In 1982 behaalde hij het artsdiploma.

$\mathrm{Na}$ enige maanden als arts-assistent te hebben gewerkt bij de afdeling Algemene Heelkunde van ziekenhuis St. Annadal, deed hij de eerste onderzoekservaring op bij JanWillem Arends op de afdeling Pathologische Anatomie van hetzelfde ziekenhuis. Vanaf 1983 is hij werkzaam bij de Rijksuniversiteit Limburg, vakgroep Epidemiologie en Biostatistiek. Eerst was hij projektmedewerker voor het in dit proefschrift beschreven onderzoek onder leiding van Prof. Dr. Paul Knipschild. Tegelijkertijd volgde hij de opleiding tot Sociaalgeneeskundige (pakket Epidemiologie) bij Prof. Dr. Ferd Sturmans, wat in 1988 in registratie uitmondde. In het kader van de scholing tot epidemioloog werden cursussen gevolgd bij onder anderen Profs. Kenneth J. Rothman, Dimitri Trichopoulos en Norman Breslow, David G. Kleinbaum en Ollie S. Miettinen.

Vanaf 1985 werkt Carel Thijs als universitair docent bij de Faculteit der Geneeskunde. 